IZA DP No. 8798

Local Political Budget Cycles in a Federation: Evidence from West German Cities

Marina Furdas

Katerina Homolkova

Krisztina Kis-Katos

January 2015 


\title{
Local Political Budget Cycles in a Federation: Evidence from West German Cities
}

\author{
Marina Furdas \\ University of Freiburg \\ Katerina Homolkova \\ University of Kiel \\ Krisztina Kis-Katos \\ University of Freiburg \\ and IZA
Discussion Paper No. 8798
January 2015 \\ IZA
P.O. Box 7240
53072 Bonn
Germany \\ Phone: +49-228-3894-0 \\ Fax: +49-228-3894-180 \\ E-mail: iza@iza.org
}

\begin{abstract}
Any opinions expressed here are those of the author(s) and not those of IZA. Research published in this series may include views on policy, but the institute itself takes no institutional policy positions. The IZA research network is committed to the IZA Guiding Principles of Research Integrity.

The Institute for the Study of Labor (IZA) in Bonn is a local and virtual international research center and a place of communication between science, politics and business. IZA is an independent nonprofit organization supported by Deutsche Post Foundation. The center is associated with the University of Bonn and offers a stimulating research environment through its international network, workshops and conferences, data service, project support, research visits and doctoral program. IZA engages in (i) original and internationally competitive research in all fields of labor economics, (ii) development of policy concepts, and (iii) dissemination of research results and concepts to the interested public.
\end{abstract}

IZA Discussion Papers often represent preliminary work and are circulated to encourage discussion. Citation of such a paper should account for its provisional character. A revised version may be available directly from the author. 


\section{ABSTRACT \\ Local Political Budget Cycles in a Federation: Evidence from West German Cities*}

This paper analyzes the occurrence of political budget cycles in 604 West German cities between 1975 and 2007. Due to the idiosyncratic timing of state and local elections, the budgetary changes before elections at two tiers of the federalist government can be separately estimated and can also be distinguished from common time effects. Both local and state elections result in pre-election manipulation of the local finances of moderate size. Before both types of elections, we observe an increase in building investments, accompanied by increasing intergovernmental grants for investment purposes but also a halt in the increase of local tax rates. By contrast, elections at the two tiers of the government affect the size of the current budget differently: current revenues and expenditures decrease before local but increase before state elections, suggesting a difference in the tightness of the local budget constraint. The extent of these political budget cycles is more pronounced in municipalities that are politically aligned with the state governments and are politically more contested.

JEL Classification: D72, H71, H72

Keywords: political budget cycles, German cities, municipal finances, local and state elections

Corresponding author:

Krisztina Kis-Katos

Institute for Economic Research

University of Freiburg

Platz der Alten Synagoge

79085 Freiburg

Germany

E-mail: krisztina.kis-katos@vwl.uni-freiburg.de

\footnotetext{
* The authors would like to thank Bernd Fitzenberger, Marta Curto Grau, Phillipp Harms, Günther Schulze and participants at the seminar in empirical economics at the University of Freiburg, the meetings of the European Public Choice Society in Cambridge, the Silvaplana 2014 workshop on political economy and the 4th Ifo workshop on regional economics in Dresden for useful comments and suggestions.
} 


\section{Introduction}

Political budget cycles arise when incumbent politicians manipulate pre-election budgets in order to improve their chances of re-election. Fiscal policy manipulation presupposes an imperfectly informed electorate that interprets changes in fiscal behaviour as a signal of the politicians' competence (Rogoff and Sibert, 1988, Rogoff, 1990; Drazen and Eslava, 2006 ; Alt and Lassen, 2006; Drazen and Eslava, 2010). The incentives to manipulate budgets are conditional on the institutional environment and the electoral competition (Aidt et al., 2011). The underlying information asymmetries can be expected to be more severe under less informed electorates (Shi and Svensson, 2006), and hence should be more prevalent in new democracies (Brender and Drazen, 2005). Nonetheless, even in more mature democratic systems like Germany, there is ample evidence of at least some fiscal manipulation before elections at the federal and state levels Berger and Woitek, 1997: Galli and Rossi, 2002; Schneider, 2010; Jochimsen and Nuscheler, 2011).

In multi-tiered governmental systems, local budgets can be affected by electoral incentives at various levels of the government. Local governments can be expected to adjust

their fiscal decisions in order to influence local election outcomes (see e.g., Drazen and Eslava, 2010; Brender, 2003 Veiga and Veiga, 2007). At the same time, local budgets may also be affected by electoral considerations of the upper-tier governments, especially if parts of the upper-tier governments' expenditures are channeled through local budgets (Veiga and Pinho, 2007; Veiga and Veiga, 2013). Electioneering at the state level can thus lead to additional changes in local budget size and composition before state elections. The incentives to manipulate budgets increase with the actual or perceived strength of the electoral competition (Aidt and Shvets, 2012; Veiga and Veiga, 2013) and may also vary with partisan preferences. Partisanship alignment between the various tiers of the government may reinforce budget cycles by aligning the re-election incentives of incumbents at different tiers of the government.

Due to its federalist structure and electoral system, Germany offers a unique case study on the interaction between local and state elections and their effects on local budget cycles. The idiosyncratic, state-wise varying, timing of elections at the two levels of government enables us to identify the effects of both types of elections on the size and composition of local budgets and to separate them from common country-wide shocks to the economy and the political system. Moreover, we can investigate whether the amplitude of the cycles varies with differences in the political environment.

The empirical analysis investigates the movements in locally set tax rates, fiscal aggregates (current expenditures and revenues) and selected items of the municipal budget 
(building investments and two types of intergovernmental grants) preceding and following 120 local and state elections between the years of 1975 and 2007. Our analysis focuses on 604 large and medium-sized cities (from eight West German states) for which long term fiscal data are available. The key fiscal variables used in the analysis rely on digitized information from the yearbooks of the Association of German Cities (1976-2008).

Our results document the presence of local political budget cycles in various fiscal outcomes. The magnitude of these cycles is, as to be expected in a mature democracy (Brender and Drazen, 2005), moderate in economic terms: in local election years local tax rates are on average by about $10 \%$ of a standard deviation lower, which is mirrored both in a decrease in current revenues and expenditures. By contrast, the decrease in local tax rates is considerably less pronounced in state election years and even goes together with an increase in current expenditures (and a pre-election increase in revenues). Both types of elections are accompanied by higher expenditures on a publicly highly visible budget item, building investments, as well as higher grants for investment purposes. These observations are consistent with pre-election budget manipulation that responds to electoral incentives faced by both tiers of the government.

In order to better understand what circumstances favour budget manipulation before elections, we further investigate whether partisanship at the local and state level or the strength of the electoral competition can help to explain the magnitude of the political budget cycles. For this purpose, we collect data on party composition of state governments as well as of municipal councils. While the identity of the ruling coalitions is well-known at the state level, we have to rely on an imputation procedure to identify the major parties based on seat distribution in the local councils. The empirical results show that municipalities that are politically aligned with the state government are less likely to raise taxes before local elections but increase building investments by more both before local and state elections. This suggests that politically aligned municipalities may have larger budgetary leeways for electioneering. Finally, we measure the strength of the electoral competition by the locally achieved margin of victory between the winning party and the second runner up in past state elections. The amplitude of the tax cycle also increases with the strength of the electoral competition as it is the highly politically contested municipalities that are able to increase their current spending before state elections.

Two further recent studies analyse political budget cycles in Germany at the local level. Foremny and Riedel (2012) investigate the determinants of the probability of an increase in the local business tax multipliers among 7738 West-German municipalities between 
2000 and 2008 and document that business taxes are less likely to increase in local election years but tend to increase after local elections. Foremny et al. (2014) focus on local political budget cycles in two West German states, Bavaria and Baden-Württemberg between 1992 and 2006. They investigate total expenditures and differentiate between the incentive effects of local council and local mayoral elections, where the effects of the latter are identified by mayors' reaching retirement age. They document budget increases both before local council and mayoral elections. In contrast to these two studies, our study focuses on a set of larger West-German cities from eight states for which longerterm statistical data exist, which enables us to consider a considerably larger number of electoral terms. We also analyze a wider range of outcomes both at the expenditure and revenue side and compare the local budgetary effects of elections at two tiers of the government. Our results present further evidence on the prevalence and extent of political budget cycles in mature democracies and highlight the interactions between electoral incentives at various levels of the government.

\section{Mechanisms, institutions and hypotheses}

\subsection{General evidence on political budget cycles}

In democracies, central bank independence renders the electoral cycles in growth, inflation and unemployment à la Nordhaus (1975) rather unlikely (Alesina and Roubini, 1992). However, fiscal policy can still serve as an instrument for electioneering. Even rational and forward-looking electorates can suffer from political budget cycles (Rogoff and Sibert, 1988): if voters lack sufficient information about the incumbent's true ability to allocate resources effectively, they will interpret an increase in the provision of debt financed public goods before an election as a signal of the incumbent's competence. Moreover, incumbents will have the incentive to shift the budget composition towards more visible and immediately observable expenditures (Rogoff, 1990). Even if the electorate can perfectly observe the incumbent's fiscal choices, the policy maker may still have the incentive to restructure fiscal expenditures towards goods valued most by swing and not by core voters (Drazen and Eslava, 2010). The magnitude of such cycles depends then on the distribution of ideological preferences, and on the amount of information about the political environment that the voters possess. If the incumbent's recent performance is informative about her unobserved ability and future performance, the incumbent's optimal inter-temporal allocation of effort may itself result in an electoral cycle (Martinez, 2009). 
Lower level governments are potentially more prone to political budget cycles as they can target expenditures to voter groups more precisely and, therefore, buy votes more efficiently. This may be counteracted by the smaller number of feasible electioneering instruments available at the local level (Drazen and Eslava, 2010; Baleiras and da Silva Costa, 2004). Besides of the ample cross-country evidence for fiscal manipulation (Alesina and Roubini, 1992, Brender and Drazen, 2005, Alt and Lassen, 2006; Klomp and De Haan, 2013), there is also substantial evidence for regional or local election cycles. Based on monthly data, Akhmedov and Zhuravskaya (2004) observe pre-election increases in total regional expenditures and deficits of Russian regions as well as a shift in the structure of expenditures in favor of spending on education, health and culture. Veiga and Veiga (2007) find increases in investment expenditures in Portuguese municipalities before elections and a subsequent increase in the share of votes for the incumbent mayor. Drazen and Eslava (2010) document shifts in the budget structure - a decrease in current and an increase in development expenditures - induced by Colombian municipal elections.

Given the relatively old democracy and the high level of fiscal transparency, Germany can be expected to be generally less prone to electioneering (Alt and Lassen, 2006; Shi and Svensson, 2006, Brender and Drazen, 2005). Nonetheless, empirical analyses find moderately sized election cycles in (West-) German states. Galli and Rossi (2002) observe budgetary shifts towards spending on administration and health before state elections as well as increasing deficits. By contrast, Schneider (2010) finds decreases in the growth in deficit spending immediately before elections accompanied by an increase in spending on social transfers. Jochimsen and Nuscheler (2011) show that the deficit reduction in preelection years is present for both coalition and non-coalition state governments. These two latter studies suggest the presence of relatively harder budget constraints at the state level that are potentially due to a more fiscally conservative electorate. Foremny and Riedel (2012) present first evidence supporting the presence of an election cycle in local business tax setting behavior in West-German municipalities, resulting in fewer tax increases before local elections. Foremny et al. (2014) document pre-election increases of the total municipal expenditures both before local council and local mayoral elections in two West-German states.

\subsection{The institutional environment}

The institutional environment of the German cities is mainly determined at the level of the German states (Länder).1 Although the autonomy of local governments is guaran-

\footnotetext{
${ }^{1}$ The following institutional details draw on Burgi $(2010)$.
} 
teed by the German Basic Law, states can decide, among others, on the municipalities' organizational structure, tasks and competences. Municipalities have to fulfill all tasks that were assigned to them by the federal and state governments, which shapes their expenditure structure. The federal government mostly assigns mandatory tasks that are identical across all states (for instance tasks related to basic administration) whereas state-assigned tasks vary across states and over time (and can refer to public order and safety, urban planning, or the construction, maintenance and management of public facilities). Additionally, municipalities can also fulfill voluntary tasks belonging to social and cultural areas or sports.

German municipalities are fiscally autonomous and manage their income and expenditures within the rules of the regular budget system. They generate their income from rents, leasing, and capital investment, concession fees, credits that are subject to state regulatory oversight, own tax revenues and intergovernmental grants. Municipalities obtain own tax revenues from three main sources: the local business tax (Gewerbesteuer), the local property tax on agricultural properties (Grundsteuer A) and the local property tax on other non-agricultural properties (Grundsteuer B). Municipalities can decide on these tax rates freely, by setting the so-called tax multipliers (Hebesätze) ${ }^{2}$ which yield - together with the value of the local tax base, determined following common federal procedures - the height of the municipal tax rates. Additionally, municipalities also receive parts of the federal income tax, of the value added tax revenue and a wide range of further transfers. Intergovernmental transfers include formula-based transfers determined by the financial equalization laws of a given state, as well as investment grants, discretionary grants for specific administrative purposes, or general purpose administrative grants. The budgeting procedure involves yearly expenditure plans that result in yearly realized expenditures.

Our empirical analysis focuses on elections of the local and state legislative assemblies. At the local level, this is the municipality council, which is the main body of selfgovernment, representing the municipality (together with its mayor), providing local legislation and controlling the administration. Members of the local council are directly elected in all states 3 Local and state elections are held on the basis of the Basic Law

\footnotetext{
2 The nation-wide reform of 2004 that restricted municipalities to have a business tax multiplier of at least 200 did not affect any of the studied municipalities; in 2003 the lowest business tax multiplier in the sample was 260 .

${ }^{3}$ By contrast, the regulation of mayoral elections varied across states and over time. Historically, West German cities were organized according to four different council constitutions, varying among others in the relative power distribution between the city council and the mayor. With the introduction of direct mayoral elections, the mayors' relative power within the municipalities tended to increase (cf. footnote 12 .
} 
and are further regulated in the election laws of the various states. This has lead to historically varying lengths of the state and local election periods and in varying rules with respect to the election dates (see table A1 for a short overview of the current state regulations). The exact date of the local and state elections is announced by the state government in advance: their timing is not subject to local electoral considerations but follows a pre-determined schedule. However, the electoral laws governing the timing of both local and state elections have been subject to a number of electoral reforms over time, which may call the exogeneity of the timing of elections in question and are further discussed in section 3.3 .

Our empirical analysis explores the variation in the timing of 120 local and state elections across eight states. In the vast majority of the analysed cases, local and state elections did not coincide, which allows us to disentangle the effects of local and state elections in the first place. Out of the analyzed local elections only every sixth was held within the same year as a state election and only one was held also within the same month (cf. table A2 .

\subsection{Local budget cycles in multi-tiered governments}

Since local budgets are affected by decisions taken both at the local and at the state level, re-election incentives at both tiers of the government may induce local political budget cycles. The resulting budget manipulation can take the form of general budget expansion, a shift towards more visible public investments, and a reduction in the likelihood of potentially unpopular measures. At the same time, elections at the two levels of government result in partly asymmetric incentives that should have differential effects on local finances. The German institutional setting, in which elections at the two lower government tiers do not generally coincide, offers a means for disentangling the effects of these different incentives on local budget cycles.

One of the main fiscal instruments within the exclusive decision power of local governments is their tax setting ability. In the context of German municipalities, the most important local taxes are the local business tax and two types of local property tax (see above). Changes in these three local tax rates are immediately observable to the public and affect a large part of the local electorate. Higher business taxes are oftentimes feared to induce local businesses to leave the municipality (Geys and Osterloh, 2013), leading to job destruction and a diminishing tax base. Increases in the tax rates on residential property affect not only property owners but also other parts of the local population through their effect on rental prices (Löffler and Siegloh, 2014). Hence, local councils 
may have the incentive not to increase taxes immediately before local elections, at least if they can afford it (this has been also documented by Foremny and Riedel, 2012). The resulting lower tax revenues may especially tighten the local budget constraint before local elections. Conversely, state elections should have no direct effect on local tax setting incentives. Nonetheless, tax setting decisions by the local councils can respond to them indirectly, depending on the state elections' effect on the local budget. Whenever state elections lead to local budgetary expansion, local councils may decide to forego local tax rate increases as a result.

While changes in local tax rates clearly reflect local council decisions, all other budgetary aggregates measured in this study arise from an interplay of local and state governments and hence cannot be attributed to any government tier exclusively. The current budget includes a host of administrative expenditures that are needed to fulfill tasks prescribed by the state, for which it can also provide the necessary resources. The state incumbent may be particularly interested in providing public funds for measures that are attributable to his actions, like the co-financing of investment projects or other clearly targetable forms of spending. State governments can affect the size of development expenditures of the investment budget by providing investment funds directly in the form of intergovernmental transfers as well as by requiring complementary project financing by the municipalities. Building investments are especially prone to pre-election manipulation (Rogoff and Sibert, 1988; Drazen and Eslava, 2005) as they result in highly visible output (roads, schools and other public buildings) that can act as a direct signal of competence. Since such investments often take a longer time horizon, the effects of electioneering may persist even after elections have taken place. Finally, the size of current revenues depends not only on locally generated revenue streams but also on a wide range of intergovernmental transfers. The size of these latter depends both on the state government's granting decisions as on the municipalities' grant application behaviour.

Political incentives and preferences can also affect the presence and magnitude of budget cycles. Political alignment between state and local governments may exacerbate the political budget cycle by aligning the re-election incentives of incumbents at the two tiers of the government, which makes local and state politicians more likely to support each other's re-election bids. The amplitude of the cycles may also increase with stronger electoral competition since the incumbents at both tiers of the government have a higher incentive to manipulate the budget if electioneering is marginally more beneficial. We expect this to be the case in politically more highly contested municipalities. Finally, left and right-leaning local and state governments may prefer to induce different types of cycles by relying more heavily on their preferred policy tools. In order to test if the 
presence of budget cycles reacts to the political incentives, the subsequent empirical analysis is differentiating between election year effects by various characteristics of the state and local polities.

\section{Data and methodology}

\subsection{Data sources}

The empirical analysis relies on an unbalanced panel of local municipal finances and local council composition for 604 large West-German municipalities. The cities included in the analysis belong to eight West German states (numbers of cities in parentheses): Baden-Württemberg (99), Bavaria (71), Hesse (59), Lower Saxony (96), North-Rhine Westphalia (220), Rheinland-Palatinate (22), the Saarland (10) and Schleswig-Holstein (21) 4 The city states of Hamburg and Bremen are not part of the dataset since they are not directly comparable to other municipalities due to their institutional characteristics. The dataset primarily includes cities with more than 20,000 inhabitants; the median city in the dataset has a population of about 35,000 .5

The annual municipal financial data are derived from hard copies of the Statistical Yearbooks of German Municipalities, published by the Association of German Cities (1976-2008) 6 The Statistical Yearbooks contain yearly data on a selective set of indicators both from the expenditure and the revenue side of the current and capital accounts and provide a unique source of long-term fiscal indicators for the largest West-German cities 7 Availability of municipal fiscal data restrict the analyzed time-span to the years between 1975 and 2007. Descriptive statistics are presented in Table 1.

The fiscal balance sheets in the yearbooks include about 20 different budgetary items

\footnotetext{
${ }^{4}$ North-Rhine-Westphalia dominates our sample: it is not only the most populous German state but due to its agglomeration area, it also has the largest number of large cities. By contrast, the second most populous state Bavaria is considerably less densely populated and has much fewer large cities in the sample.

5 The dataset has been assembled by Furdas and Kis-Katos (2010) and extended to include the dates of local and state elections, state election results, partisanship of the state governments and state level economic outcomes.

${ }^{6}$ Founded in 1905, the Association of German Cities (Deutscher Städtetag) is the largest national federation of municipalities including more than 3400 localities. It represents interests of municipalities in dealings with the Federal Government and other national and supranational organizations (Deutscher Städtetag, 2014).

7 The collection and provision of German municipal data is organized at the state level and municipal data is not readily available for some states or goes back to considerably shorter time periods.
} 
per year, from which the statistical analysis focuses on five major budget outcomes plus on separately recorded information on local tax multipliers. Variables are selected for the statistical analysis if they fulfill the majority of the following criteria: (1) they are a relevant measure of local public finances, (2) they are attributable to local or state decisions, (3) they are not redundant and (4) are consistently measured across time. For instance, we include the total size of the current budget because it is highly relevant although not easily attributable, but do not use information that refers to accounting shifts between the current and capital accounts because of smaller relevance and comparability across time. We also exclude the information on mandatory transfers of local taxes to the upper tiers of the government, or on interest rate payments, since these are pre-determined by law or previous decisions (and hence non-attributable). We focus on major items (like building investment) but not on sub-categories (investment in building roads or schools) and combine the three locally set tax multipliers into one local tax variable in order to reduce redundancy. Finally, we exclude a whole range of variables that were strongly affected by changes in accounting rules and definitions over time, like the credit flow variables which first included and then excluded internal credits (comparability).

Beyond balance sheet information, the Statistical Yearbooks also report the current magnitude of the locally set tax multipliers for the business tax, the tax on agricultural and on non-agricultural properties. Moreover, they provide yearly information on local population size as well as on the seat composition of the local councils across the major parties, which are used to generate explanatory variables. Further explanatory variables are based on the election dates for state and local elections, collected from the State Election Offices (Landeswahlleiter), and local partisan vote shares in state elections, available from the Statistical Offices of each state. Finally, state-level series of unemployment rates come from the Federal Employment Agency whereas real GDP per capita (with the base year of 1995) and its growth rate come from the Federal Statistical Office and state Statistical Offices.

\subsection{Variables and hypotheses}

\subsubsection{Dependent variables}

Our first dependent variable is a composite measure of Local tax rates, which are legislated by the local councils directly and hence should be especially well suited to reflect local budgetary incentives over the electoral cycle. The variable combines information 
on the three locally set tax multipliers yielding the local business tax, the tax on agricultural and the tax on non-agricultural properties (see section 2.2). The three local tax multipliers have been all increasing steadily over the analyzed time period (cf. figure 1). Since they are highly correlated and the timing of their changes has often coincided, for the empirical analysis we extract their first principal component (shown in figure 1 as a dashed line) and use it as a composite dependent variable. However, since tax rates on mobile and immobile factors (businesses vs. property) can be expected to react to the inter-jurisdictional competition between cities to a different extent (Janeba and Osterloh, 2013), we also show separate results for the three tax rates under further results in section 4.3 .

The other five dependent variables measure the size and the composition of the local budgets in per capita terms. They refer to expenditures realized in a given year and hence do not reflect budget plans but actual yearly realization of the budget instead. They are deflated using a national consumer price index with the base year of 1995. Current expenditures capture the expenditure side of the current account and include a wide range of expenditures on personnel, materials, social services, interest rate payments and all other non-investment items. Current revenues capture the revenue side of the current account and include revenues from local taxes, fees and other charges, formulabased shares of national tax revenues and inter-communal transfers, various grants from the different tiers of the government as well as transfers from the capital account. As figure 2 shows, in most years, the average municipality in the sample ran moderate surpluses on the current account, which were then transferred to the capital account. Current expenditures and revenues are included in the analysis to detect changes in the total budget size induced by the timing of local and state elections. However, because of their aggregated nature, they do not only respond to decisions of the local governments but are also affected by financial decisions of upper government tiers.

Because of changes in reporting procedures in 1986, we do not have comparable aggregate measures for the total size of the capital account. On the expenditure side the capital account mainly includes building investments and the acquisition of investment goods, on the revenue side it includes transfers from the current account, intergovernmental transfers for investment purposes, own capital revenues, revenues from asset sales and borrowing. From all these capital expenditures we focus on one of the most visible expenditure items, Building expenditures. These include construction of roads and public infrastructure like schools or sewage systems and have been reported in the same form across the whole time period. 
In order to capture the effects of electoral incentives on intergovernmental relations more directly, we additionally include the magnitudes of two types of intergovernmental transfers: general per capita transfers to the current account that we label Administrative grants, and per capita grants for investment purposes, or Investment grants. The administrative grants represent a composite category that includes formula based equalizing transfers (Schlüsselzuweisungen), earmarked discretionary administrative grants for selected specific purposes, for instance to be used in case of local budget crises (Bedarfszuweisungen), as well as other non-earmarked general purpose grants (sonstige allgemeine Zuweisungen). The category of investment grants (Investitionszuweisungen) mainly includes, beyond of a basic general purpose component, grants earmarked for investment purposes, often requiring co-financing from the municipalities. If investment expenditures generally tended to increase before elections, this may be mirrored in the movement of investment grants. At the same time electoral incentives may also lead to a short-term substitution between the two types of grants.

The digitized data from the statistical yearbooks of the Association of German Cities yields a municipal time series of unique length but it comes at the cost of higher data entry errors in the original yearbooks. In order to reduce the related measurement errors, we trim all five budgetary variables by setting the upper and lower $1 \%$ of their distribution to missing. By this procedure we are removing extremely low and high values of the financial variables - for instance negative expenditure values - that are most likely due to errors in data entry. On the same account, we clean the yearly series of tax multipliers by replacing one-year-spikes in each multiplier with the neighboring values if the values of earlier and later years are equal (and change thereby tax multipliers for 130 city-year observations or $0.79 \%$ of all).

For the regression analysis all dependent variables are expressed in a standardized form with a mean zero and a standard deviation of one. The magnitude of the coefficients is thus directly comparable across the different dependent variables and specifications.

\subsubsection{Explanatory variables}

The main explanatory variables consist of a set of indicators for election, pre-election and post-election years. We code two sets of indicators: one for local and another one for state election years. An election year is the year in which regular local or state elections took place, whereas the pre/post-election year is the one preceding/following an election. The inclusion of post-election year indicators may be especially important to capture the cycle in expenditure items that are realized more sluggishly. For instance, 
the realization of building investments can take longer than originally planned, which may increase the election-induced expenditures even after elections.

To check the robustness of our results towards cycle definitions, we alternatively use a further set of election year indicators, re-defining the pre/post-election year variables as a fraction of the number of months in a year preceding or following an election 8 These indicators capture the scope for electioneering more precisely as local expenditures in a given year will have a smaller chance influencing election outcomes if elections take place at the beginning of the year. Moreover, the alternative election year indicators additionally distinguish between those state and local elections that took place within the same year but in different months (cf. table A2). As an alternative robustness check, we also examine a longer electoral cycle, involving three years before a local or state election.

Further political controls at the local and state levels are derived from the party composition of state governments, the seat composition of local councils, and local results in election for the state assembly. At the state level we code a Left state government indicator, which equals one if during the previous year the Social Democratic Party (SPD) has been in the government either alone or as part of a coalition and takes zero otherwise. Left state governments were present for about $53 \%$ of city-year observations. The four other parties that also entered some of the state governments are the conservative Christian Democratic Union (CDU) and its Bavarian equivalent, the Christian Socialist Union (CSU), the liberal Free Democratic Party (FDP) and the Green Party (Die Grünen). Most of the coalition governments at the state level were formed including parties from the same wing (CDU, CSU, FDP as opposed to the SPD and the Greens), with the exception of the socio-liberal coalition (between SPD and FDP, for some years in Nord-Rhine Westphalia and Hesse) and the grand coalition (between CDU and SPD, in Baden-Württemberg).

At the local level we rely on an imputation procedure to determine the partisanship of local councils since data on actual coalitions at the local level is not available in a systematic way. Matters are further complicated as in some states local council members can also be supported by voters' associations (potentially also affiliated to some parties) or run as free candidates. Local coalitions often also include parties that are too small to enter the upper tiers of the government. These institutional constraints limit the

\footnotetext{
8 If the elections take place in month $m$, the alternative pre-election year indicator takes $(m-1) / 12$ in the election year and $(13-m) / 12$ in the year before that, the alternative postelection year indicator takes $(13-m) / 12$ in the election year and $(m-1) / 12$ in the year after that. Comparable measures have been used in the literature Schneider (2010); Klomp and De Haan (2013).
} 
reliability of partisanship measures at the municipal level. For our imputation procedure we focus on the party (or other political grouping) with the largest number of seats in the local council as it is most likely to be the one to decide on forming a local coalition government. We hence code the variable Left local government to take one if the SPD held the largest number of local seats as compared to all other parties and nonpartisan council members during the previous year $9^{9}$ Data on the seat distribution across local parties comes from the Statistical Yearbooks of German Municipalities (Association of German Cities, 1976-2008).

In order to test for interactions between the ruling parties at the local and state levels, we additionally define the indicator variable of Partisanship alignment. Based on the state and local partisanship data, it indicates all cases when the party winning the most seats in a local council was also part of the state government during the previous year. In case of coalition governments at the state level, we consider the local council to be politically aligned with the state if either of the state government parties received a relative majority of local council seats. Using this definition, about $55 \%$ of city-year observations in our dataset refer to politically aligned local and state governments.

As a further determinant of political incentives, we also consider the strength of partisan competition at the local level measured by the margin of victory in previous state elections within the municipality (MOV in state elections). The margin of victory is defined as the difference between the vote shares achieved by the parties with the largest and the second largest number of votes 10 The electoral outcomes in past state elections may not only proxy for the strength of local competition by state politicians but can also capture the overall competitiveness of the local political environment. The use of past election data to code this variable restricts our sample as in some states detailed election data are available for shorter time periods only ${ }^{11}$

All regressions include the size of the local population (in 10,000 inhabitants, from the Statistical Yearbook of German Municipalities) in order to control for potential scale effects due to differential population growth. Constitutional reforms during the analyzed study period contributed to the shift in power between the local council and

\footnotetext{
${ }^{9}$ During our observation period, none of the other leftist parties managed to hold a relative majority of the local council seats.

${ }^{10}$ We focus on local outcomes of state elections rather than municipal council election results because of better data coverage and the more limited number of contestant parties which reduces aggregation problems.

11 Municipal-level data on results in state elections is available starting from 1981 for BadenWürttemberg, from 1984 for Hesse, from 1994 for Rhineland-Palatinate, from 1981 for the Saarland, and is not available for Schleswig-Holstein.
} 
the mayor and, thus, most likely affected budgetary outcomes. We control for this policy change in a rather rudimentary way, by including an indicator for the years following the introduction of direct mayoral elections. This electoral reform increased the relative power of local mayors to a different extent, depending on the previous state constitution 12 Since this indicator varies only little across time and states, it is likely to also capture other average time differences in outcomes at the state level, which are not directly related to this specific institutional detail. Hence, the indicator should not be given a causal interpretation.

In further robustness checks we control for more detailed economic outcomes at the state level in order to correct for biases due to local or state elections coinciding with statespecific economic shocks. For this purpose we include the lagged state GDP per capita and its growth rate and lagged unemployment rates at the state level.

\subsection{Empirical Approach}

\subsubsection{Baseline model}

Due to differences in the timing of elections across states and across the various tiers of the federal government, we can disentangle the election year effects from common time effects capturing the federal election cycle and other common macroeconomic shocks. The empirical setup enables us thus to identify changes in local budgetary outcomes that were related to the timing of local and state elections.

As a baseline model, we estimate the following equation:

$$
Y_{i t}=\beta L E L(\tau)_{i t}+\delta S E L(\tau)_{i t}+\gamma X_{i t}+\lambda_{i}+\kappa_{t}+\epsilon_{i t}
$$

where $Y_{i t}$ denotes the budgetary variable of municipality $i$ in year $t . \quad L E L(\tau)_{i t}$ and $S E L(\tau)_{i t}$ consist of two vectors of indicators for the timing of local and state elections, where the elements of the vector $L E L(\tau)=[L E L(T-1), L E L(T), L E L(T+1)]$ take 1 if $t=\tau$ (where $t$ stands for the current year, $\tau \in\{T-1, T, T+1\}$ and $T$ is the election year) and 0 otherwise. $S E L$ is determined in the same way. $X_{i t}$ is the vector of further controls (in the baseline, population size and an indicator for directly elected mayors), $\lambda_{i}$ and $\kappa_{t}$ are municipality and time fixed effects, and $\epsilon_{i t}$ is the error term. In the baseline

12 The constitutional reform at the state level that established the authority of a directly elected mayor became legally effective in 1952 in Bavaria, in 1953 in Baden-Württemberg, in 1993 in Hesse, in 1994 in the Saarland and Rhineland-Palatinate, in 1996 in Lower Saxony, in 1998 in Schleswig-Holstein and in 1999 in Nord Rhine-Westphalia (Burgi, 2010). 
we estimate panel data models that are purged of municipality fixed effects through a demeaning transformation. Municipality fixed effects control for time-invariant sources of heterogeneity across municipalities like institutional status and geographic location of the municipalities. The time fixed effects control for economic and political shocks common to all West-German cities as well as common changes in budgetary procedures over time. We cluster standard errors at municipality level to correct for the autocorrelation in budgetary variables 13

Since we are interested in electoral cycles in multiple budgetary outcomes, our analysis faces the challenge of multiple variable testing that could lead to spuriously significant results, purely due to the number of considered outcomes. We deal with this concern in two ways. First, we excluded a whole range of budgetary items from the analysis from the beginning because of missing comparability over time, missing attributability to local or state governments, or their marginal relevance. We combine the remaining relevant information into as few variables as possible and use the first principal component of the tax rates, or use total building expenditures but not its sub-categories in our regressions. Second, we acknowledge that all budgetary variables are jointly determined within the same budgeting process and hence cannot be considered to be independent from each other. In statistical terms, we allow for a correlation between our six selected budgetary variables by estimating them jointly in a seemingly unrelated regression (SUR) model and base our estimates of significance of the specific coefficients on Bonferroni-adjusted $p$-values. The Bonferroni method adjusts the individual $p$-values by $k$, the number of concurrent tests being executed (in our baseline case, $k=6$ ) and results in $p_{i}^{B}=$ $\min \left(k p_{i}, 1\right)$. This method is relatively strict, yielding conservative $p$-values, and is very unlikely to overestimate the significance of an electoral cycle.

\subsubsection{Further specifications}

In a second step, we test whether the magnitude of the electoral budget cycles changes under different political constellations. For this purpose we extend equation (1) to include two types of interaction effects. First, we investigate whether the coincidence of elections at the two tiers of the government reinforced or mitigated the magnitude of budget cycles. Out of the 56 local elections in our sample, 9 fell within the same calendar year as the state elections, although only in one case did the timing of the two elections coincide fully (cf. table A2). By adding interaction terms between the post-election, election and pre-election years at the two tiers of government, we capture additional

\footnotetext{
${ }^{13}$ Augmented Dickey-Fuller tests do not reject the null hypothesis of (trend) stationary panels.
} 
differences in the amplitude of the cycles when the two election years coincide.

Furthermore, we introduce a set of interactions between our indicators for the timing of local and state elections and further political variables, one at a time. Among the political controls we include partisanship alignment between the state government and the major party in the local council, the strength of electoral competition measured by the margin of victory at state elections as well as partisanship at the state and local level.

In order to check the sensitivity of our baseline results to definitions of the election cycle, we re-estimate equation (1) with alternatively defined election year indicators (see above). Additionally, we also show results for a longer electoral cycle that goes from $t-3$ to $t$. Further robustness checks extend the set of controls to include state-level controls for the yearly economic cycle.

In our main empirical analysis we opted for the use of jointly estimated fixed effects models, where a full set of year fixed effects controls for common time patterns in the investigated variables and municipality level clustering deals with autocorrelation of the error terms. However, the autocorrelation of fiscal variables can also be introduced more directly into the models by including their first (or further) lagged values as explanatory variables. Since the observation period is relatively long ( $T=33$ years), the endogeneity bias resulting from the inclusion of a lagged dependent variable would be relatively small (as it goes to $1 / T$ ). Nonetheless, we re-estimate these models by the method of general moments, (GMM, Arellano and Bond, 1991), using difference GMM with a correction for two-step estimation (Windmeijer, 2005). We treat the lagged dependent variables as endogenous and further economic controls (population, directly elected mayor, lagged state unemployment rate, lagged state GDP and lagged state GDP growth rate) as predetermined. The preferred lag length of the lagged dependent and of the included instruments is selected by using diagnostic tests and tests for overidentification of the instruments.

\subsubsection{Endogeneity concerns}

Our analysis treats the timing of state and local elections as plausibly exogenous to local budgetary decisions. By including a full set of year fixed effects, we control for all economic and political shocks that were common to all West German municipalities. Since state and local election dates are set by the states, they are also not subject to local manipulation and do not respond to local variation in economic conditions. However, we cannot exclude that local finances could be affected by state-specific economic shocks. If 
states were to set local and state election dates systematically in response to such statespecific economic shocks, this would invalidate our identification strategy. If elections were systematically more likely to be held in years with a more favourable economic environment, this would result in a budget cycle in itself. We argue that the extent of this problem is contained in our specific case study and discuss the related issues.

First, we note that in Germany the timing of local and state elections generally follows a pre-defined schedule of four, five or six years, and the length of the electoral period did not generally coincide between the two tiers of the government (cf. table A2). The spacing of local and state elections is defined by each state's electoral laws and has been subject to only sporadic legislative changes. The length of the local electoral period changed in several states in the late 1970es (in Baden-Württemberg, Hesse, Lower Saxony and North-Rhine Westphalia) as well as around 2000 (Hesse and SchleswigHolstein). Following a national trend, the length of the electoral period for state elections increased in five out of the eight states around the middle or end of the 1990es and converged to the now common length of five years (cf. table A1). However, these electoral reforms had to be decided well in advance and hence it is very unlikely that the timing of future elections at either tier of the government was precisely driven by a state-specific economic cycle. Since some states have a larger freedom to set the election dates within the year, our alternative election indicators (see above) are potentially more affected by endogeneity concerns and are reported only in the robustness section $4.3^{14}$ Moreover, we address the remaining issue of correlation between state-specific economic shocks and the timing of elections more explicitly in section 4.3 by re-estimating our main models with controls for state-specific economic conditions in form of lagged values of real state GDP p.c., GDP growth rates and state unemployment rates.

A second issue arises because of early elections that follow government crises as their timing coincides with political and/or economic problems, which once again calls the exogenous timing of elections into question. In the case of local governments, we disregard the eventual presence of irregular elections caused by local government crises, and impute for each municipality the date of the state-scheduled regular local elections. The resulting measurement error in the local election year variables biases our estimates of the magnitude of the local political budget cycles downward. In the case of state elections, we deal with government crises more explicitly. As table A2 shows, during

\footnotetext{
${ }^{14}$ Currently, the month of local elections is pre-determined in three out of eight states whereas the month can be somewhat more freely set in the remaining states; the month of state elections has mostly to lie within a 3-month bound around the end of the election period (cf. table A1). De facto, election months have stayed fixed within the year in half of the state-election series (cf. table A2.
} 
the analyzed time period state government crises were relatively rare events: In two cases state elections had to be repeated because a government could not be formed: this happened in Hesse in 1982 and 1983 and in Schleswig-Holstein in 1987 and 1988. In Lower Saxony the government changed without elections in 1976 and 1977, after which elections were held in 1978. Since government crises naturally disrupt a normal election cycle, we exclude the 355 observations referring to these seven state-year pairs from the analysis altogether and do not use these elections for calculating pre- and post-election year indicators.

Third, we might be concerned that the timing of direct mayoral elections in the municipalities confounds our analysis. However, the dates for mayoral elections are generally not synchronized with local elections and are often determined by the municipalities directly (early elections) or depend on personal circumstances (mayors reaching the age limit or withdrawing prematurely). Since mayoral terms are in most states also longer than those of the local council, it is highly unlikely that both types of elections would have coincided consistently over time and hence mayoral elections should not systematically drive our electoral cycle effects. Not controlling for their timing will thus lead to a further attenuation bias in our measures of a political budget cycle. Foremny et al. (2014) support this assertion by showing that in municipalities of Bavaria and Baden-Württemberg from 1992 to 2006, additionally controlling for the timing of mayoral elections does not change the magnitude of local council election effects on the total budget 15

We also want to emphasize that controls for the political environment like partisanship, partisanship alignment or past margin of victory cannot be considered as exogenous as they are determined by former electoral outcomes and hence potentially reflect timevariant changes in electoral preferences. Keeping this in mind, the differential magnitude of electoral cycles under different types of partisan constellations still yields itself to a descriptive interpretation.

\footnotetext{
${ }^{15}$ As compared to the study of Foremny et al. (2014), our sample additionally includes many cities that used to belong to other council constitutions than the two Southern states (especially cities belonging to the North German council constitution are numerous), which granted considerably smaller powers to the local mayors and among others, did not elect mayors directly (see also footnote 12). Thus, in our sample the importance of mayoral elections should be relatively smaller as compared to their study.
} 


\section{Results}

\subsection{Baseline results}

Table 2 presents regression results based on equation (1). The dependent variables measure local tax rates in column (1), current expenditures and revenues in columns (2-3), capital investments in building in column (4) and the size of intergovernmental grants in columns (5-6).

Tax rates appear to be lower by about $10 \%$ of a standard deviation in the year of local elections. Since average tax rates increased steadily over the analyzed time period (cf. figure 11, this implies that local councils were reluctant to increase local taxes in the election phase. The post-election tax coefficient stays still negative after local elections but is statistically significantly lower than the election year effect: this shows that any tax increases introduced immediately after the elections do not fully compensate for the election year effect. These lower taxes go together with an overall decrease in the size of the current budget. Current revenues decrease thereby by somewhat more before elections than expenditures do, which also results in a lowering of the average current account surplus. Budget size stays lower in the aftermath of local elections as well, which may partly reflect a temporary disruption in the "business as usual" due to the necessary reformation of the local council but can also be induced by the still low tax revenues. This interpretation is supported by the changes observed around state elections that do not affect the local councils directly, only through their effects on the budget constraint. While local taxes are marginally lower in state election years, potentially reflecting an overall loosening of the budget constraint around state elections, both current expenditures and revenues increase in the year before state elections by about $4 \%$ of a standard deviation (or 14 Euros per capita in 1995 prices). Expenditures (though not revenues) stay higher in state election years as well and both expenditures and revenues go back to normal immediately after state elections ${ }^{16}$

Investment expenditures on buildings and construction increase by about $8 \%$ of a standard deviation before both types of elections. For local elections, this documents a considerable shift in budget composition (from current to investment expenditures) that is concentrated in the period preceding local elections. This increase in investment spending is accompanied by higher intergovernmental grants disbursed for investment

\footnotetext{
16 Our results stay in contrast with the increase in local expenditures before local council elections in municipalities of Bavaria and Baden-Württemberg, documented by Foremny et al. (2014). Since we only focus on larger cities, on more West-German states and a considerably longer time period, this difference can be due to sample differences along any of those dimensions.
} 
purposes whereas administrative grants do not increase and potentially even decrease slightly before elections. Changes in the size of intergovernmental transfers both reflect changes in grant application behavior of the municipal councils as well as in granting behavior of the upper tiers of the government. The increase in investment grants after local elections can be explained by a time lag between grant application and disbursement as well as by follow-up costs of investment projects that were not entirely completed until elections. The increase in building investments before state elections is slightly differently timed as it is concentrated in the election and post-election years. The higher investment spending may be part of re-election campaign spending by the state incumbent that is channelled through local budgets, but it may also reflect an overall loosening of the local budget constraints before state elections. The results on intergovernmental grants support the first interpretation - only the disbursement of investment grants is higher in state election years, that of administrative grants is not-whereas the missing substitution between current and investment expenditures lends some support to the second. Among the controls, population is insignificant throughout, while the large and significant coefficients on the indicator for the institution of a directly elected mayor cannot be given any causal interpretation.

Overall, the results confirm the presence of election cycles in fiscal aggregates Rogoff and Sibert, 1988). The budget items with the largest observed electoral cycles are local taxes that decrease and building investments that increase before elections. These changes are consistent with the observed decrease of current expenditures and revenues around local elections. Moreover, local governments seem to be more constrained in their choices around local elections than around state elections as there is no comparable reduction in current expenditures and revenues before state elections. The presence of such electoral budget cycles in Germany is in itself an interesting result as it contradicts the expectation that more experienced voters cannot be fooled by pre-election budget manipulation and hence there should be no budget cycles in mature democracies Alt and Lassen, 2006. Shi and Svensson, 2006, Brender and Drazen, 2005).

Table 3 investigates further the role of election timing by setting a set of interaction terms for local and state elections that happen within the same year. When local and state elections broadly coincide, the electioneering interests of the local and state governments are more strongly aligned and could reinforce each other, which may lead to an increase in the amplitude of the local budget cycles. This is indeed what we find. Local taxes are somewhat less likely to be raised in an ordinary local election year, but this effect is more than six times larger in those election (and post-election) years where local and state elections coincide. The same is true for building investments, which increase by 
considerably more around concurrent elections. Current revenues and expenditures are significantly higher in concurrent pre-election years. Moreover, for local elections that happen on their own, there is also a clearer shift from administrative to investment grants before the elections, which is on average masked by a countervailing effect of concurrent elections on administrative grants.

\subsection{Political determinants of the budget cycles}

Further results in tables 4 to 7 investigate how the amplitude of the budget cycles changes with local politics. While the presence of a local political budget cycle is interesting per se, its roots can be better understood by distinguishing between different political environments that may give rise to cycles to a different extent. However, partisan constellations or the strength of electoral competition at the local level are not exogenously given but also depend on the local socio-economic environment, past budgetary outcomes and the resulting electoral preferences. Thus, the following results are only of an indicative nature and do not allow for a strictly causal interpretation. Nonetheless, since the timing of the elections has a large random component in it, differences in cycles in different types of political environments still yield themselves to a descriptive interpretation.

Partisanship alignment between the local and state governments affects the magnitude of the political budget cycles (table 4). While local elections lead to a decrease in current revenues and expenditures both in aligned and non-aligned municipalities, only politically aligned municipalities have statistically (and economically) significantly lower taxes around local elections. The magnitude of the electoral cycle in building investments is also significantly larger in aligned municipalities, both in local and state election years. Non-aligned municipalities receive significantly lower administrative grants in state election years so that a shift in the granting behavior from administrative to investment grants becomes more likely; the same does not hold for the politically aligned municipalities. Given these results, we cannot exclude the possibility of at least some differential support from the state governments to the electoral bids of the politically aligned municipal councils, which would allow these latter not to raise local taxes before local elections, increase building investments before both types of elections and reduce substitution between the two types of grants. As contrasting evidence, non-aligned municipalities receive higher investment grants after the local election year, however, even this apparently positive result could be due to slower grant disbursement to non-aligned councils.

Models including the margin of victory in past state elections show that political bud- 
get cycles also change with the strength of state electoral competition at the local level (table 5). The baseline cycle coefficients give the amplitude of the cycle for municipalities with very close past state election results whereas the interaction terms show the changes in the cycle with increasing margins of victory and hence reductions in electoral competition. The cycle in local tax rates is strongest in electorally highly contested municipalities and gets mitigated as the electoral competition reduces. Before local elections, current expenditures are reduced by more in highly contested municipalities than in ones with lower electoral competition. These two sets of results are consistent with local councils being especially constrained by electoral competition in their tax setting behavior and reducing their current expenditures as a result. Interestingly, state election years yield a different pattern of taxes and current expenditures: in this case stronger electoral competition is related to lower taxes but at the same time to higher current expenditures 17 This is in line with a relaxation of the local budget constraint due to re-election incentives by the state governments as these try to provide more resources to highly contested municipalities, enabling them to both raise current expenditures and lower taxes around state elections. But even if so, there is no statistical evidence that flows of labelled grants are contributing to this phenomenon. We also do not see statistically significant differences between the building investment cycle in more or less contested municipalities.

Further two tables (6) and 7) show several differences between the average magnitudes of the electoral cycle under leftist state governments or under leftist local council majority. The results suggest that under state governments that include the left wing party there is somewhat less financial scope for pre-election manipulation. Under left-wing state governments local taxes are higher in the local pre-election year and may even increase before state elections, the current revenue reductions around local elections are larger, and the revenue increases around state elections are smaller. The shift from administrative to investment grants around state elections is also only present under left state governments. By contrast, for current expenditures and building investments no very strong differences appear. Local councils with a left party majority are less subject to a loosening of the budget constraint before state elections: they are less likely not to increase local taxes before state elections and spend less on building investments in state (but similarly also in local) pre-election years. These partisan differences in the electoral cycles are not necessarily due to different partisan preferences between left and right governments but may also reflect different economic and fiscal constraints under which left and right governments operate.

17 Coefficients on revenues are smaller and are not significant in state election years. 
Our empirical setup does not allow us to attribute the cycle exclusively to one of the above considered political factors, especially since electoral outcomes cannot be considered exogenous. Most likely, there are further interactions between electoral contest, partisan alignment between the tiers, partisanship and election timing at the two tiers of the government, which cannot be fully captured in this modelling framework. The results document however that on average political considerations plausibly contribute to variations in the extent of electoral budget manipulation.

\subsection{Robustness and further results}

In order to better control for the timing of elections within the year, table 8 replicates the baseline results from table 2 using an alternative measure of the election indicators. These indicators substitute the local and state election year indicators with the share of months of the year that fell before or after the given election (cf. footnote 8). The results of table 8 fully confirm the baseline estimates. While coefficients on the election years increase due to the difference in scaling, the results are almost identical both for pre-election manipulation of budget size and budget structure. Additional results from the complementary appendix show that partisan alignment between the two tiers of government leads to larger reductions in local tax rates and larger building expenditures before local elections; non-aligned municipalities also seem to experience a shift from administrative towards investment grants after state elections whereas aligned municipalities do not (table A3). Larger political competition leads to stronger decreases in revenues before and to stronger decreases in expenditures after local elections whereas the local tax coefficients become insignificant around state elections (table A4). Despite of this last finding, the results broadly confirm the results of table 4.

A further robustness check of the way election timing is measured in the empirical model involves specifications that include indicators for a cycle up to three years before elections (table 9). The excluded baseline category comprises the post-election years in states with electoral cycles of five or six years. The results from this longer cycle specification also broadly confirm our findings at the baseline (table 2). Local taxes are relatively lower in local election years but also in state election years (when compared to all other coefficients of the longer cycle). Current revenues and expenditures are relatively higher before state elections whereas building investments and investment grants are higher in local and state election years. For administrative grants the gradient is much less clear-cut, confirming our previous mainly insignificant results.

In order to address the concern that election timing may be correlated with state-specific 
economic shocks that could be driving our cycle results, table 10 extends the baseline model to include lagged state economic controls. The results show that the local fiscal outcomes are strongly correlated with state economic controls in the previous year. More importantly, most of our baseline findings are not sensitive to the inclusion of these additional controls, suggesting that the observed budget cycles indeed arise because of political incentives, not because of state-specific economic shocks. As with the previous robustness checks, the results on the main political interactions seem to be more sensitive to specification changes: while they can be confirmed in their spirit, they mostly show reduced significance (tables A5 and A6).

While all previous results considered local tax rates jointly, table 11 repeats the baseline results (from table 2) for the three separate tax multipliers. Theoretically, we expect the business tax to be more strongly affected by inter-jurisdictional competition than the property taxes (as capital is more mobile than home or agricultural land ownership). Indeed, the business tax multipliers turn out to be the most sensitive to local election timing, being about $13 \%$ of a standard deviation lower in local election years. They are followed by taxes on local non-agricultural property (with -7\%) and taxes on local agricultural property (with $-4 \%$ ). By contrast, state election years see a comparable (and less sizeable) reduction in all three tax multipliers. The detailed results also show that it is higher business taxes in pre-election years that drive the positive combined tax coefficient for those years. Nonetheless, with $3 \%$ of a standard deviation, the increase in the business tax multiplier in local pre-election years is still considerably smaller than the subsequent tax reduction in the local election year. The last specification in the table measures changes in the trend of tax increases and hence the estimated coefficients roughly correspond to the difference between the coefficients of column (1). The results confirm the presence of smaller tax increases in local and state election years and also show that although taxes are still relatively lower in a local post-election year (column 1), these years already experience minor tax increases. The positive pre-election year coefficients disappear in this specification.

Finally, we check for the robustness of our overall results to the selected estimation technique. Table 12 re-estimates our baseline models extended by state-level economic controls (reported in table 10) using difference GMM estimators, with two to three lags of the dependent variable as further controls 18 Coefficients on the lagged dependent show that local taxes are the most, investment grants the least autocorrelated. As compared to the baseline results, GMM estimates show some minor changes in the timing of the

\footnotetext{
${ }^{18}$ Further GMM estimates on partisanship alignment and electoral competition can be found in tables A7 and A8.
} 
election effects but corroborate the overall findings. The only major difference between the two sets of results is that unlike in the SUR models, GMM estimates show decreases in current revenues not only in years with local elections but also in state election and post-election years. Nevertheless, for the pre-election years the results still confirm our previous interpretation of potential differences in the budget constraint: revenues are increasing somewhat before state and decreasing more strongly before local elections.

\section{Conclusion}

This paper documented the presence of political budget cycles in 604 West German cities over 33 years. The main innovation of the analysis was to identify local budget cycles that are affected by elections at two different tiers of the federal government, which was possible due to the idiosyncratic timing of state and local elections across German states. From a theoretical perspective, incumbents at both tiers of the government have an incentive to influence voters immediately before elections. Thereby, fiscal decisions of local councils would be reflected in local budgets directly whereas funding decisions by the state governments would exert a more indirect influence. Indeed, the results show that the closeness of both local and state elections affects local budgets considerably, but it does so in a non-symmetric way.

The study considered the evolution of locally set tax rates, total current expenditures and revenues, expenditures on building investment and two forms of intergovernmental grants (for administrative and investment purposes). The analysis mainly relied on jointly estimated models with municipality and time fixed effects and indicators for the two election cycles. The empirical results showed the most pronounced cycles in local tax setting (tax rates are less likely to be increased before elections), but also in building investments and the related investment grants, all of which changed by about $8-10 \%$ of a standard deviation around election years. This contradicts the notion that political budget cycles should vanish in countries with more mature democracies and more experienced voters.

Interestingly, elections at the two tiers of the government also had some differential effects on local budgetary outcomes. State elections were related to an overall increase in current expenditures and potentially even revenues (despite of the non-increasing local taxes). By contrast, local elections involved not only decreasing taxes but also lower current expenditures and revenues as well as a shift from administrative towards investment grants. The two sets of results are supportive of the idea of a harder local budget con- 
straint before local than before state elections. Further descriptive results documented somewhat larger political budget cycles both in municipalities that had a council which was politically aligned with the state government as well as in politically more contested municipalities. They thus offered suggestive evidence that political budget cycles vary with the strength of the electoral competition as well as with the political alignment of multi-tiered governments. 


\section{References}

Aidt, T. S. and Shvets, J. (2012). Distributive politics and electoral incentives: Evidence from seven us state legislatures. American Economic Journal: Economic Policy 4(3), $1-29$.

Aidt, T. S., Veiga, F. J. and Veiga, L. G. (2011). Election results and opportunistic policies: A new test of the rational political business cycle model. Public Choice $148(1-2), 21-44$.

Akhmedov, A. and Zhuravskaya, E. (2004). Opportunistic political cycles: Test in a young democracy setting. The Quarterly Journal of Economics 119(4), 1301-1338.

Alesina, A. and Roubini, N. (1992). Political cycles in OECD economies. Review of Economic Studies 59(4), 663-688.

Alt, J. E. and Lassen, D. D. (2006). Fiscal transparency, political parties, and debt in oecd countries. European Economic Review 50(6), 1403 - 1439.

Arellano, M. and Bond, S. (1991). Some tests of specification for panel data: Monte Carlo evidence and an application to employment equations. Review of Economic Studies 58(2), 277-297.

Association of German Cities (1976-2008). Statistisches Jahrbuch Deutscher Gemeinden, Jahrgang 62-95. Köln, Deutscher Städtetag.

Baleiras, R. N. and da Silva Costa, J. (2004). To be or not to be in office again: An empirical test of a local political business cycle rationale. European Journal of Political Economy 20(3), 655-671.

Berger, H. and Woitek, U. (1997). Searching for political business cycles in Germany. Public Choice 91(2), 179-197.

Brender, A. (2003). The effect of fiscal performance on local government election results in Israel: 1989-1998. Journal of Public Economics 87(9-10), 2187-2205.

Brender, A. and Drazen, A. (2005). Political budget cycles in new versus established democracies. Journal of Monetary Economics 52(7), 1271-1295.

Burgi, M. (2010). Kommunalrecht. Munich, Verlag C.H. Beck, 3 ed.

Deutscher Städtetag (2014). Association of German Cities. http://www.staedtetag. de/englisch/index.html. 
Drazen, A. and Eslava, M. (2005). Electoral manipulation via expenditure composition: Theory and evidence. Working Paper 11085, National Bureau of Economic Research, Cambridge, Massachusetts.

Drazen, A. and Eslava, M. (2006). Pork barrel cycles. NBER Working Papers 12190, National Bureau of Economic Research, Inc, Cambridge, Massachusetts.

Drazen, A. and Eslava, M. (2010). Electoral manipulation via voter-friendly spending: Theory and evidence. Journal of Development Economics 92(1), 39-52.

Foremny, D., Freier, R., Moessinger, M.-D. and Yeter, M. (2014). Overlapping political budget cycles in the legislative and the executive. Working paper, Deutsches Institut für Wirtschaftsforschung, Berlin.

Foremny, D. and Riedel, N. (2012). Business taxes and the electoral cycle. Working paper 3729, CESifo, Munich.

Furdas, M. and Kis-Katos, K. (2010). Does partisanship affect local fiscal policies? A regression discontinuity analysis for West German cities. Mimeo, University of Freiburg.

Galli, E. and Rossi, S. P. S. (2002). Political budget cycles: The case of the Western German Lander. Public Choice 110(3-4), 283-303.

Geys, B. and Osterloh, S. (2013). Borders as boundaries to fiscal policy interactions? an empirical analysis of politicians' opinions on rivals in the competition for firms. Journal of Regional Science 53(4), 583-606.

Janeba, E. and Osterloh, S. (2013). Tax and the city - a theory of local tax competition. Journal of Public Economics 106, 89-100.

Jochimsen, B. and Nuscheler, R. (2011). The political economy of the German Lander deficits: Weak governments meet strong finance ministers. Applied Economics 43(19), 2399-2415.

Klomp, J. and De Haan, J. (2013). Do political budget cycles really exist? Applied Economics 45(3), 329-341.

Löffler, M. and Siegloh, S. (2014). Property taxes and rental housing. Unpublished working paper, mimeo. 
Martinez, L. (2009). A theory of political cycles. Journal of Economic Theory 144(3), $1166-1186$.

Nordhaus, W. D. (1975). The political business cycle. Review of Economic Studies 42(2), 169-190.

Rogoff, K. (1990). Equilibrium political budget cycles. American Economic Review 80(1), 21-36.

Rogoff, K. and Sibert, A. (1988). Elections and macroeconomic policy cycles. Review of Economic Studies 55(1), 1-16.

Schneider, C. J. (2010). Fighting with one hand tied behind the back: Political budget cycles in the West German states. Public Choice 142(1-2), 125-150.

Shi, M. and Svensson, J. (2006). Political budget cycles: Do they differ across countries and why? Journal of Public Economics 90(8-9), 1367-1389.

Veiga, L. G. and Pinho, M. M. (2007). The political economy of intergovernmental grants: Evidence from a maturing democracy. Public Choice 133(3/4), 457-477.

Veiga, L. G. and Veiga, F. J. (2007). Does opportunism pay off? Economics Letters 96(2), 177-182.

Veiga, L. G. and Veiga, F. J. (2013). Intergovernmental fiscal transfers as pork barrel. Public Choice 155(3/4), 335-353.

Windmeijer, F. (2005). A finite sample correction for the variance of linear efficient two-step GMM estimators. Journal of Econometrics 126(1), 25-51. 


\section{Figures}

Figure 1: Development of local tax multipliers over time

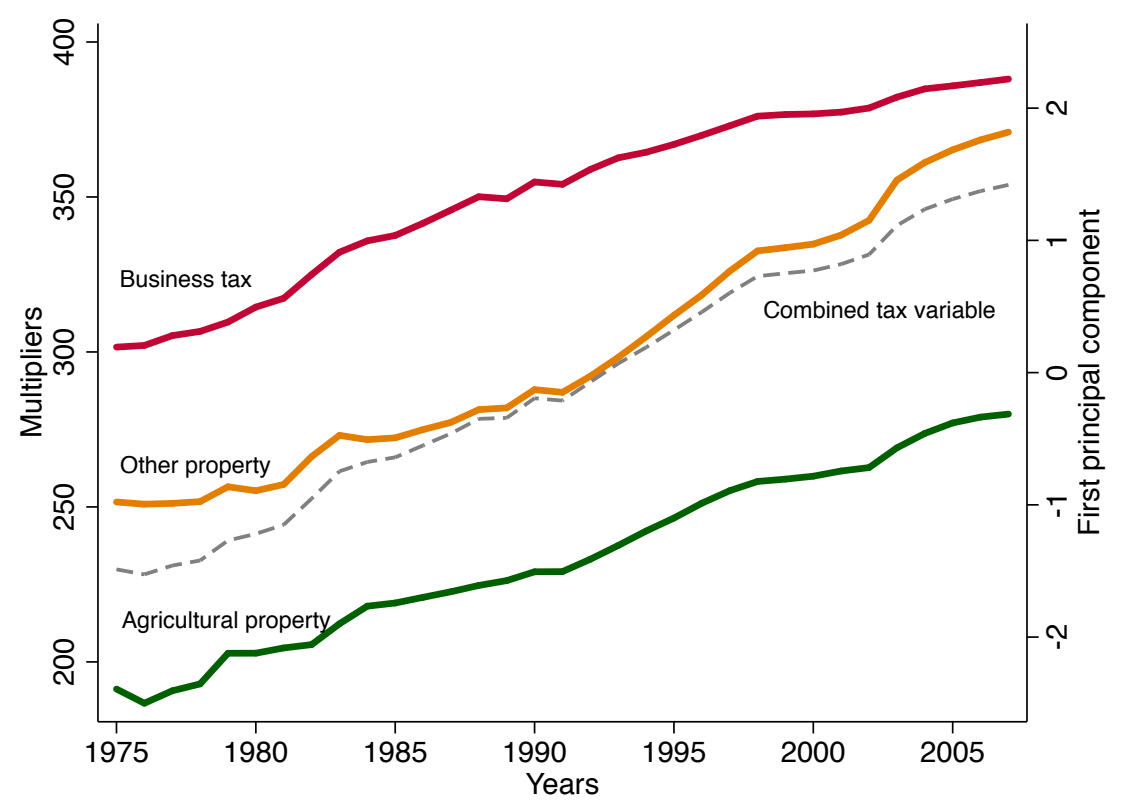

Note: The figure shows yearly averages of the municipal tax multipliers for taxes on business, agricultural and non-agricultural property. The average combined tax variable (dashed line) is determined as the first principal component of the three tax multipliers.

Figure 2: Development of selected budget items over time (EUR pc.)
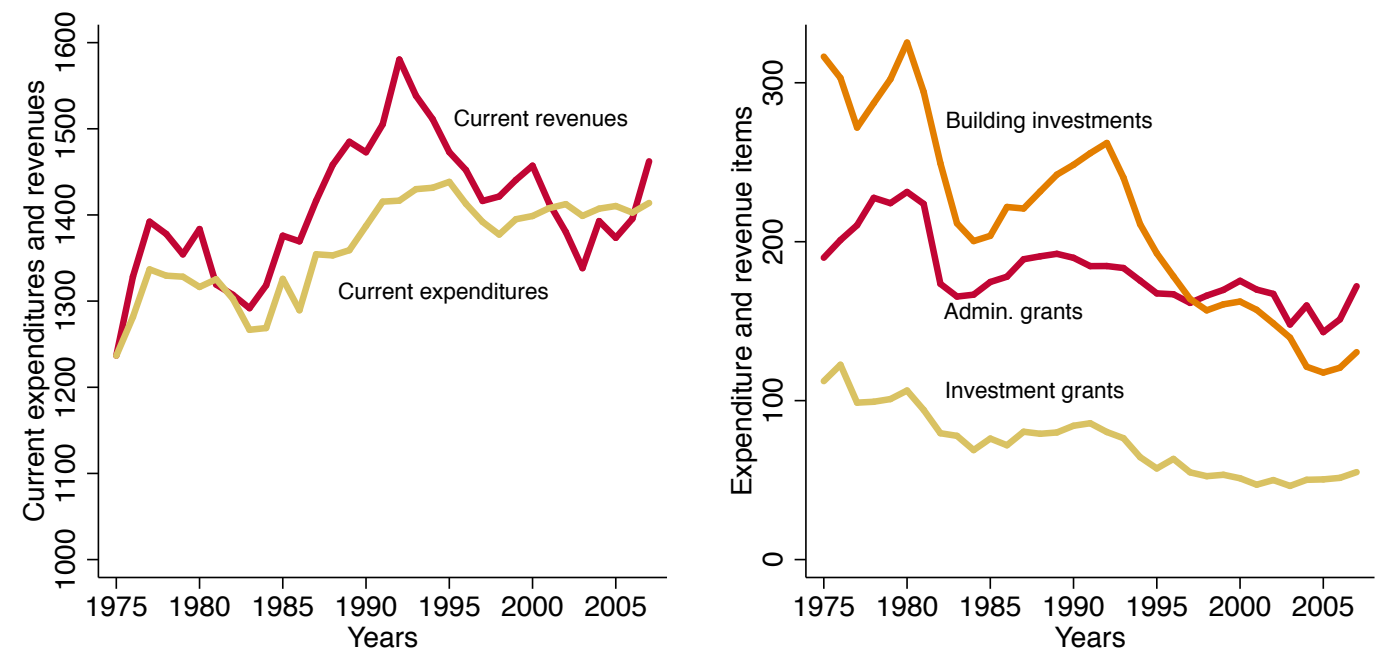

Note: The figure shows yearly averages of real per capita budget items (in 1995 EUR terms). 


\section{Tables}

Table 1: Descriptive statistics

\begin{tabular}{lrrrrr}
\hline & $\mathrm{N}$ & Mean & Std. Dev. & Min & Max \\
\hline Current expenditures pc. & 16103 & 1368.475 & 364.788 & 736.845 & 2703.195 \\
Current revenues pc. & 16101 & 1411.140 & 345.659 & 803.693 & 2684.106 \\
Building investment expenditures pc. & 16084 & 209.361 & 114.386 & 33.133 & 628.817 \\
Local tax rates (first principal component) & 16378 & 0.001 & 1.431 & -3.738 & 5.615 \\
Central grants to admin. budget pc. & 15971 & 179.802 & 100.738 & 5.637 & 456.745 \\
Central grants for investment purposes pc. & 16043 & 71.542 & 49.627 & 2.686 & 292.102 \\
Directly elected mayor & 16407 & 0.536 & 0.499 & 0 & 1 \\
Population (in 10.000) & 16407 & 6.575 & 10.696 & 1.096 & 131.552 \\
Local post-election year & 16407 & 0.206 & 0.405 & 0 & 1 \\
Local election year & 16407 & 0.206 & 0.402 & 0 & 1 \\
Local pre-election year & 16407 & 0.198 & 0.398 & 0 & 1 \\
State post-election year & 16407 & 0.232 & 0.422 & 0 & 1 \\
State election year & 16407 & 0.216 & 0.412 & 0 & 1 \\
State pre-election year & 16407 & 0.215 & 0.411 & 0 & 1 \\
Alternative local post-election year & 16407 & 0.207 & 0.287 & 0 & 0.833 \\
Alternative local pre-election year & 16407 & 0.199 & 0.283 & 0 & 0.833 \\
Alternative state post-election year & 16407 & 0.225 & 0.305 & 0 & 1 \\
Alternative state pre-election year & 16407 & 0.216 & 0.306 & 0 & 1 \\
State government left & 15779 & 0.591 & 0.492 & 0 & 1 \\
Local government left & 15050 & 0.315 & 0.464 & 0 & 1 \\
Partisan alignment & 15050 & 0.552 & 0.497 & 0 & 1 \\
MOV in state elections & 13478 & 0.157 & 0.115 & 0.000 & 0.743 \\
Lagged state unemployment rate & 16407 & 8.132 & 2.897 & 1.400 & 16.600 \\
Lagged state GDP pc. (1.000 EUR) & 16407 & 22.097 & 3.277 & 14.237 & 29.360 \\
Lagged state GDP growth rate & 16407 & 1.538 & 1.880 & -5.229 & 6.511 \\
\hline
\end{tabular}


Table 2: The local electoral budget cycle (SUR w. mun./year FE)

\begin{tabular}{|c|c|c|c|c|c|c|}
\hline \multirow{3}{*}{ Dependent variable } & & $(2)$ & (3) & \multirow{3}{*}{$\begin{array}{c}(4) \\
\text { Building } \\
\text { investment }\end{array}$} & \multirow{3}{*}{$\begin{array}{c}(5) \\
\text { Admin. } \\
\text { grants }\end{array}$} & \multirow{3}{*}{$\begin{array}{c}\quad(6) \\
\text { Invest. } \\
\text { grants }\end{array}$} \\
\hline & Local & \multicolumn{2}{|c|}{ Current account } & & & \\
\hline & tax rates & Expend. & Revenues & & & \\
\hline Local post-election year & $\begin{array}{c}-0.068 * * \\
(0.005) \\
{[0.000]}\end{array}$ & $\begin{array}{c}-0.059 * * \\
(0.009) \\
{[0.000]}\end{array}$ & $\begin{array}{c}-0.057 * * \\
(0.010) \\
{[0.000]}\end{array}$ & $\begin{array}{c}0.000 \\
(0.015) \\
{[1.000]}\end{array}$ & $\begin{array}{c}-0.007 \\
(0.009) \\
{[1.000]}\end{array}$ & $\begin{array}{c}0.044+ \\
(0.018) \\
{[0.086]}\end{array}$ \\
\hline Local election year & $\begin{array}{c}-0.103 * * \\
(0.007) \\
{[0.000]}\end{array}$ & $\begin{array}{c}-0.037 * * \\
(0.009) \\
{[0.000]}\end{array}$ & $\begin{array}{c}-0.064 * * \\
(0.010) \\
{[0.000]}\end{array}$ & $\begin{array}{c}0.081 * * \\
(0.017) \\
{[0.000]}\end{array}$ & $\begin{array}{c}-0.015 \\
(0.008) \\
{[0.385]}\end{array}$ & $\begin{array}{c}0.109 * * \\
(0.018) \\
{[0.000]}\end{array}$ \\
\hline Local pre-election year & $\begin{array}{c}0.017 * \\
(0.006) \\
{[0.023]}\end{array}$ & $\begin{array}{c}0.004 \\
(0.009) \\
{[1.000]}\end{array}$ & $\begin{array}{c}-0.034 * * \\
(0.010) \\
{[0.002]}\end{array}$ & $\begin{array}{l}0.085 * * \\
(0.016) \\
{[0.000]}\end{array}$ & $\begin{array}{c}-0.022+ \\
(0.009) \\
{[0.097]}\end{array}$ & $\begin{array}{l}0.076 * * \\
(0.018) \\
{[0.000]}\end{array}$ \\
\hline State post-election year & $\begin{array}{c}-0.004 \\
(0.005) \\
{[1.000]}\end{array}$ & $\begin{array}{c}0.005 \\
(0.008) \\
{[1.000]}\end{array}$ & $\begin{array}{c}-0.002 \\
(0.009) \\
{[1.000]}\end{array}$ & $\begin{array}{l}0.061 * * \\
(0.013) \\
{[0.000]}\end{array}$ & $\begin{array}{c}-0.009 \\
(0.009) \\
{[1.000]}\end{array}$ & $\begin{array}{c}0.015 \\
(0.015) \\
{[1.000]}\end{array}$ \\
\hline State election year & $\begin{array}{c}-0.026 * * \\
(0.005) \\
{[0.000]}\end{array}$ & $\begin{array}{c}0.046 * * \\
(0.008) \\
{[0.000]}\end{array}$ & $\begin{array}{l}0.010 \\
(0.009) \\
{[1.000]}\end{array}$ & $\begin{array}{c}0.086 * * \\
(0.015) \\
{[0.000]}\end{array}$ & $\begin{array}{c}-0.006 \\
(0.009) \\
{[1.000]}\end{array}$ & $\begin{array}{l}0.088 * * \\
(0.016) \\
{[0.000]}\end{array}$ \\
\hline State pre-election year & $\begin{array}{l}0.026 * * \\
(0.004) \\
{[0.000]}\end{array}$ & $\begin{array}{c}0.039 * * \\
(0.008) \\
{[0.000]}\end{array}$ & $\begin{array}{l}0.042 * * \\
(0.008) \\
{[0.000]}\end{array}$ & $\begin{array}{c}0.018 \\
(0.013) \\
{[0.871]}\end{array}$ & $\begin{array}{c}0.012 \\
(0.008) \\
{[1.000]}\end{array}$ & $\begin{array}{c}0.007 \\
(0.016) \\
{[1.000]}\end{array}$ \\
\hline Population & $\begin{array}{c}-0.003 \\
(0.008) \\
{[1.000]}\end{array}$ & $\begin{array}{c}-0.014 \\
(0.011) \\
{[1.000]}\end{array}$ & $\begin{array}{c}-0.005 \\
(0.017) \\
{[1.000]}\end{array}$ & $\begin{array}{c}-0.014 \\
(0.017) \\
{[1.000]}\end{array}$ & $\begin{array}{c}-0.014 \\
(0.014) \\
{[1.000]}\end{array}$ & $\begin{array}{c}-0.014 \\
(0.014) \\
{[1.000]}\end{array}$ \\
\hline Directly elected mayor & $\begin{array}{c}0.389 * * \\
(0.037) \\
{[0.000]}\end{array}$ & $\begin{array}{c}0.207 * * \\
(0.032) \\
{[0.000]}\end{array}$ & $\begin{array}{c}0.037 \\
(0.030) \\
{[1.000]}\end{array}$ & $\begin{array}{c}0.014 \\
(0.040) \\
{[1.000]}\end{array}$ & $\begin{array}{c}-0.196 * * \\
(0.034) \\
{[0.000]}\end{array}$ & $\begin{array}{c}0.104+ \\
(0.040) \\
{[0.057]}\end{array}$ \\
\hline $\begin{array}{l}\text { No. observations } \\
\text { No. municipalities }\end{array}$ & $\begin{array}{c}16378 \\
604\end{array}$ & $\begin{array}{c}16103 \\
601\end{array}$ & $\begin{array}{c}16101 \\
599\end{array}$ & $\begin{array}{c}16084 \\
602\end{array}$ & $\begin{array}{c}15971 \\
604\end{array}$ & $\begin{array}{c}16043 \\
601\end{array}$ \\
\hline
\end{tabular}

Notes: The models rely on standardized dependent variables, originally measured in constant Euro per capita, except for the tax rate which is the standardized first principal component of three local tax multipliers. The six equations are jointly estimated in a seemingly unrelated regression (SUR) framework, controlling for municipality and year fixed effects. Standard errors clustered at the municipality level are presented in parentheses. Bonferroni-adjusted p-values (adjusted for multiple variable testing) are reported in square brackets. $+/^{*} / * *$ denote significance at the $10 / 5 / 1 \%$ level, adjusted for multiple variable testing. 
Table 3: Local-state cycle interactions (SUR w. mun./year FE)

\begin{tabular}{|c|c|c|c|c|c|c|}
\hline \multirow{3}{*}{ Dependent variable } & (1) & (2) & $(3)$ & \multirow{3}{*}{$\begin{array}{c}(4) \\
\text { Building } \\
\text { investment }\end{array}$} & \multirow{3}{*}{$\begin{array}{c}\text { (5) } \\
\text { Admin. } \\
\text { grants }\end{array}$} & \multirow{3}{*}{$\begin{array}{c}\quad(6) \\
\text { Invest. } \\
\text { grants }\end{array}$} \\
\hline & Local & \multicolumn{2}{|c|}{ Current account } & & & \\
\hline & tax rates & Expend. & Revenues & & & \\
\hline Local post-election year & $\begin{array}{c}-0.008 \\
(0.006) \\
{[1.000]}\end{array}$ & $\begin{array}{c}-0.043 * * \\
(0.011) \\
{[0.000]}\end{array}$ & $\begin{array}{c}-0.024 \\
(0.011) \\
{[0.178]}\end{array}$ & $\begin{array}{c}-0.018 \\
(0.018) \\
{[1.000]}\end{array}$ & $\begin{array}{c}-0.012 \\
(0.010) \\
{[1.000]}\end{array}$ & $\begin{array}{l}0.082 * * \\
(0.020) \\
{[0.000]}\end{array}$ \\
\hline Local election year & $\begin{array}{c}-0.036 * * \\
(0.007) \\
{[0.000]}\end{array}$ & $\begin{array}{c}-0.038 * * \\
(0.010) \\
{[0.001]}\end{array}$ & $\begin{array}{c}-0.057 * * \\
(0.011) \\
{[0.000]}\end{array}$ & $\begin{array}{c}0.030 \\
(0.019) \\
{[0.712]}\end{array}$ & $\begin{array}{c}-0.036 * * \\
(0.009) \\
{[0.001]}\end{array}$ & $\begin{array}{l}0.115 * * \\
(0.020) \\
{[0.000]}\end{array}$ \\
\hline Local pre-election year & $\begin{array}{c}0.029 * * \\
(0.007) \\
{[0.001]}\end{array}$ & $\begin{array}{c}-0.015 \\
(0.010) \\
{[0.899]}\end{array}$ & $\begin{array}{c}-0.068 * * \\
(0.011) \\
{[0.000]}\end{array}$ & $\begin{array}{c}0.053 * \\
(0.018) \\
{[0.016]}\end{array}$ & $\begin{array}{c}-0.042 * * \\
(0.011) \\
{[0.001]}\end{array}$ & $\begin{array}{c}0.059 * \\
(0.019) \\
{[0.010]}\end{array}$ \\
\hline State post-election year & $\begin{array}{c}0.037 * * \\
(0.005) \\
{[0.000]}\end{array}$ & $\begin{array}{c}0.006 \\
(0.009) \\
{[1.000]}\end{array}$ & $\begin{array}{c}0.003 \\
(0.009) \\
{[1.000]}\end{array}$ & $\begin{array}{c}0.033 \\
(0.014) \\
{[0.118]}\end{array}$ & $\begin{array}{c}-0.021 \\
(0.010) \\
{[0.190]}\end{array}$ & $\begin{array}{c}0.026 \\
(0.016) \\
{[0.668]}\end{array}$ \\
\hline State election year & $\begin{array}{c}-0.012 \\
(0.005) \\
{[0.177]}\end{array}$ & $\begin{array}{l}0.028 * \\
(0.009) \\
{[0.013]}\end{array}$ & $\begin{array}{c}-0.020 \\
(0.010) \\
{[0.283]}\end{array}$ & $\begin{array}{l}0.048 * \\
(0.016) \\
{[0.021]}\end{array}$ & $\begin{array}{c}-0.026+ \\
(0.010) \\
{[0.080]}\end{array}$ & $\begin{array}{l}0.063 * * \\
(0.018) \\
{[0.003]}\end{array}$ \\
\hline State pre-election year & $\begin{array}{c}-0.007 \\
(0.005) \\
{[1.000]}\end{array}$ & $\begin{array}{c}0.020+ \\
(0.008) \\
{[0.083]}\end{array}$ & $\begin{array}{c}0.003 \\
(0.009) \\
{[1.000]}\end{array}$ & $\begin{array}{c}0.015 \\
(0.014) \\
{[1.000]}\end{array}$ & $\begin{array}{l}0.005 \\
(0.009) \\
{[1.000]}\end{array}$ & $\begin{array}{c}-0.022 \\
(0.017) \\
{[1.000]}\end{array}$ \\
\hline $\begin{array}{l}\text { Local post-election year } \times \\
\text { State post-election year }\end{array}$ & $\begin{array}{c}-0.269 * * \\
(0.021) \\
{[0.000]}\end{array}$ & $\begin{array}{c}-0.035 \\
(0.028) \\
{[1.000]}\end{array}$ & $\begin{array}{r}-0.084 * \\
(0.027) \\
{[0.010]}\end{array}$ & $\begin{array}{c}0.134 * \\
(0.048) \\
{[0.029]}\end{array}$ & $\begin{array}{c}0.050 \\
(0.029) \\
{[0.502]}\end{array}$ & $\begin{array}{c}-0.122+ \\
(0.050) \\
{[0.089]}\end{array}$ \\
\hline $\begin{array}{l}\text { Local election year } \times \\
\text { State election year }\end{array}$ & $\begin{array}{c}-0.202 * * \\
(0.022) \\
{[0.000]}\end{array}$ & $\begin{array}{c}0.045 \\
(0.027) \\
{[0.611]}\end{array}$ & $\begin{array}{c}0.053 \\
(0.025) \\
{[0.210]}\end{array}$ & $\begin{array}{c}0.220 * * \\
(0.044) \\
{[0.000]}\end{array}$ & $\begin{array}{l}0.098 * * \\
(0.025) \\
{[0.001]}\end{array}$ & $\begin{array}{c}0.046 \\
(0.053) \\
{[1.000]}\end{array}$ \\
\hline $\begin{array}{l}\text { Local pre-election year } \times \\
\text { State pre-election year }\end{array}$ & $\begin{array}{c}0.032 \\
(0.021) \\
{[0.796]}\end{array}$ & $\begin{array}{l}0.103 * * \\
(0.028) \\
{[0.002]}\end{array}$ & $\begin{array}{c}0.194 * * \\
(0.028) \\
{[0.000]}\end{array}$ & $\begin{array}{c}0.113+ \\
(0.044) \\
{[0.066]}\end{array}$ & $\begin{array}{l}0.078 * \\
(0.029) \\
{[0.041]}\end{array}$ & $\begin{array}{c}0.114 \\
(0.052) \\
{[0.162]}\end{array}$ \\
\hline No. observations & 16378 & 16103 & 16101 & 16084 & 15971 & 16043 \\
\hline No. municipalities & 604 & 601 & 599 & 602 & 604 & 601 \\
\hline
\end{tabular}

Notes: The models rely on standardized dependent variables, originally measured in constant Euro per capita, except for the tax rate which is the standardized first principal component of three local tax multipliers. All models control for local population and an indicator for directly elected mayors. The six equations are jointly estimated in a seemingly unrelated regression (SUR) framework, controlling for municipality and year fixed effects. Standard errors clustered at the municipality level are presented in parentheses. Bonferroni-adjusted p-values (adjusted for multiple variable testing) are reported in square brackets. $+/^{*} / * *$ denote significance at the $10 / 5 / 1 \%$ level, adjusted for multiple variable testing. 
Table 4: Partisanship alignment and cycles (SUR w. mun./year FE)

\begin{tabular}{|c|c|c|c|c|c|c|}
\hline \multirow[b]{2}{*}{ Dependent variable } & (1) & (2) & (3) & \multirow{2}{*}{$\begin{array}{c}\text { (4) } \\
\text { Building } \\
\text { investment }\end{array}$} & \multirow{2}{*}{$\begin{array}{c}(5) \\
\text { Admin. } \\
\text { grants }\end{array}$} & \multirow{2}{*}{$\begin{array}{c}\quad(6) \\
\text { Invest. } \\
\text { grants }\end{array}$} \\
\hline & $\begin{array}{c}\text { Local } \\
\text { tax rates }\end{array}$ & \multicolumn{2}{|c|}{ Current account } & & & \\
\hline Local post-election year & $\begin{array}{c}-0.004 \\
(0.009) \\
{[1.000]}\end{array}$ & $\begin{array}{c}-0.046 * * \\
(0.013) \\
{[0.003]}\end{array}$ & $\begin{array}{c}-0.066 * * \\
(0.015) \\
{[0.000]}\end{array}$ & $\begin{array}{c}0.010 \\
(0.021) \\
{[1.000]}\end{array}$ & $\begin{array}{c}-0.029 \\
(0.013) \\
{[0.168]}\end{array}$ & $\begin{array}{l}0.116 * * \\
(0.024) \\
{[0.000]}\end{array}$ \\
\hline Local election year & $\begin{array}{c}-0.015 \\
(0.011) \\
{[0.877]}\end{array}$ & $\begin{array}{c}-0.048 * * \\
(0.014) \\
{[0.006]}\end{array}$ & $\begin{array}{c}-0.079 * * \\
(0.015) \\
{[0.000]}\end{array}$ & $\begin{array}{c}0.022 \\
(0.026) \\
{[1.000]}\end{array}$ & $\begin{array}{c}-0.038+ \\
(0.014) \\
{[0.050]}\end{array}$ & $\begin{array}{l}0.095 * * \\
(0.026) \\
{[0.002]}\end{array}$ \\
\hline Local pre-election year & $\begin{array}{l}0.073 * * \\
(0.009) \\
{[0.000]}\end{array}$ & $\begin{array}{c}0.014 \\
(0.012) \\
{[1.000]}\end{array}$ & $\begin{array}{c}-0.042 * \\
(0.014) \\
{[0.013]}\end{array}$ & $\begin{array}{c}0.016 \\
(0.022) \\
{[1.000]}\end{array}$ & $\begin{array}{c}-0.054 * * \\
(0.013) \\
{[0.000]}\end{array}$ & $\begin{array}{c}0.066 * \\
(0.025) \\
{[0.046]}\end{array}$ \\
\hline State post-election year & $\begin{array}{r}-0.025 * \\
(0.009) \\
{[0.019]}\end{array}$ & $\begin{array}{c}-0.003 \\
(0.011) \\
{[1.000]}\end{array}$ & $\begin{array}{c}-0.012 \\
(0.014) \\
{[1.000]}\end{array}$ & $\begin{array}{l}0.046 \\
(0.022) \\
{[0.201]}\end{array}$ & $\begin{array}{c}-0.026 \\
(0.014) \\
{[0.399]}\end{array}$ & $\begin{array}{c}0.001 \\
(0.024) \\
{[1.000]}\end{array}$ \\
\hline State election year & $\begin{array}{c}-0.012 \\
(0.011) \\
{[1.000]}\end{array}$ & $\begin{array}{l}0.056 * * \\
(0.014) \\
{[0.001]}\end{array}$ & $\begin{array}{l}0.018 \\
(0.016) \\
{[1.000]}\end{array}$ & $\begin{array}{c}0.012 \\
(0.026) \\
{[1.000]}\end{array}$ & $\begin{array}{c}-0.054 * * \\
(0.015) \\
{[0.003]}\end{array}$ & $\begin{array}{c}0.059 \\
(0.025) \\
{[0.109]}\end{array}$ \\
\hline State pre-election year & $\begin{array}{c}-0.028 * \\
(0.009) \\
{[0.018]}\end{array}$ & $\begin{array}{c}0.030 \\
(0.014) \\
{[0.214]}\end{array}$ & $\begin{array}{l}0.036 * \\
(0.013) \\
{[0.037]}\end{array}$ & $\begin{array}{c}-0.007 \\
(0.021) \\
{[1.000]}\end{array}$ & $\begin{array}{l}0.008 \\
(0.014) \\
{[1.000]}\end{array}$ & $\begin{array}{c}-0.038 \\
(0.025) \\
{[0.783]}\end{array}$ \\
\hline $\begin{array}{l}\text { Partisan alignment } \times \\
\text { local post-election year }\end{array}$ & $\begin{array}{c}-0.049 * * \\
(0.012) \\
{[0.000]}\end{array}$ & $\begin{array}{l}0.004 \\
(0.016) \\
{[1.000]}\end{array}$ & $\begin{array}{c}0.034 \\
(0.018) \\
{[0.311]}\end{array}$ & $\begin{array}{c}-0.027 \\
(0.028) \\
{[1.000]}\end{array}$ & $\begin{array}{c}0.025 \\
(0.017) \\
{[0.896]}\end{array}$ & $\begin{array}{c}-0.103 * \\
(0.033) \\
{[0.012]}\end{array}$ \\
\hline $\begin{array}{l}\text { Partisan alignment } \times \\
\text { local election year }\end{array}$ & $\begin{array}{c}-0.111 * * \\
(0.013) \\
{[0.000]}\end{array}$ & $\begin{array}{c}0.031 \\
(0.018) \\
{[0.438]}\end{array}$ & $\begin{array}{l}0.032 \\
(0.018) \\
{[0.466]}\end{array}$ & $\begin{array}{c}0.062 \\
(0.035) \\
{[0.423]}\end{array}$ & $\begin{array}{l}0.038 \\
(0.019) \\
{[0.272]}\end{array}$ & $\begin{array}{c}-0.006 \\
(0.035) \\
{[1.000]}\end{array}$ \\
\hline $\begin{array}{l}\text { Partisan alignment } \times \\
\text { local pre-election year }\end{array}$ & $\begin{array}{c}-0.104 * * \\
(0.011) \\
{[0.000]}\end{array}$ & $\begin{array}{c}-0.017 \\
(0.014) \\
{[1.000]}\end{array}$ & $\begin{array}{c}0.003 \\
(0.016) \\
{[1.000]}\end{array}$ & $\begin{array}{l}0.089 * * \\
(0.026) \\
{[0.004]}\end{array}$ & $\begin{array}{c}0.039 \\
(0.017) \\
{[0.128]}\end{array}$ & $\begin{array}{c}0.003 \\
(0.030) \\
{[1.000]}\end{array}$ \\
\hline $\begin{array}{l}\text { Partisan alignment } \times \\
\text { state post-election year }\end{array}$ & $\begin{array}{c}0.025 \\
(0.011) \\
{[0.105]}\end{array}$ & $\begin{array}{c}0.018 \\
(0.013) \\
{[1.000]}\end{array}$ & $\begin{array}{l}0.006 \\
(0.016) \\
{[1.000]}\end{array}$ & $\begin{array}{l}0.026 \\
(0.026) \\
{[1.000]}\end{array}$ & $\begin{array}{c}0.019 \\
(0.017) \\
{[1.000]}\end{array}$ & $\begin{array}{c}0.031 \\
(0.029) \\
{[1.000]}\end{array}$ \\
\hline $\begin{array}{l}\text { Partisan alignment } \times \\
\text { state election year }\end{array}$ & $\begin{array}{c}-0.000 \\
(0.015) \\
{[1.000]}\end{array}$ & $\begin{array}{c}-0.003 \\
(0.018) \\
{[1.000]}\end{array}$ & $\begin{array}{c}-0.026 \\
(0.019) \\
{[1.000]}\end{array}$ & $\begin{array}{l}0.088 * \\
(0.031) \\
{[0.029]}\end{array}$ & $\begin{array}{l}0.070 * * \\
(0.020) \\
{[0.002]}\end{array}$ & $\begin{array}{c}0.027 \\
(0.033) \\
{[1.000]}\end{array}$ \\
\hline $\begin{array}{l}\text { Partisan alignment } \times \\
\text { state pre-election year }\end{array}$ & $\begin{array}{c}0.012 \\
(0.012) \\
{[1.000]}\end{array}$ & $\begin{array}{c}-0.008 \\
(0.018) \\
{[1.000]}\end{array}$ & $\begin{array}{c}-0.003 \\
(0.017) \\
{[1.000]}\end{array}$ & $\begin{array}{c}0.061 \\
(0.028) \\
{[0.196]}\end{array}$ & $\begin{array}{l}0.031 \\
(0.019) \\
{[0.650]}\end{array}$ & $\begin{array}{c}0.067 \\
(0.034) \\
{[0.283]}\end{array}$ \\
\hline $\begin{array}{l}\text { Partisan alignment } \\
\text { state-local gov. }\end{array}$ & $\begin{array}{c}0.022 \\
(0.022) \\
{[1.000]}\end{array}$ & $\begin{array}{c}-0.040 \\
(0.021) \\
{[0.350]}\end{array}$ & $\begin{array}{c}-0.025 \\
(0.021) \\
{[1.000]}\end{array}$ & $\begin{array}{r}-0.095 * \\
(0.033) \\
{[0.022]}\end{array}$ & $\begin{array}{c}-0.083 * * \\
(0.023) \\
{[0.002]}\end{array}$ & $\begin{array}{c}0.022 \\
(0.033) \\
{[1.000]}\end{array}$ \\
\hline No. c & $\begin{array}{c}15046 \\
580\end{array}$ & $\begin{array}{c}14806 \\
578\end{array}$ & $\begin{array}{c}14816 \\
577\end{array}$ & $\begin{array}{c}14758 \\
580\end{array}$ & $\begin{array}{c}14628 \\
580\end{array}$ & $\begin{array}{c}14746 \\
579\end{array}$ \\
\hline
\end{tabular}

Notes: The models rely on standardized dependent variables, originally measured in constant Euro per capita, except for the tax rate which is the standardized first principal component of three local tax multipliers. All models control for local population and an indicator for directly elected mayors. The partisanship alignment variable takes 1 if in the previous year the party with the most seats in the local council was also part of the state government. The six equations are jointly estimated in a seemingly unrelated regression (SUR) framework, controlling for municipality and year fixed effects. Standard errors clustered at the municipality level are presented in parentheses. Bonferroni-adjusted p-values (adjusted for multiple variable testing) are reported in square brackets. $+/^{*} /{ }^{* *}$ denote significance at the $10 / 5 / 1 \%$ level, adjusted for multiple variable testing. 
Table 5: Electoral competition and cycles (SUR w. mun./year FE)

\begin{tabular}{|c|c|c|c|c|c|c|}
\hline \multirow{3}{*}{ Dependent variable } & \multirow{3}{*}{$\begin{array}{c}(1) \\
\text { Local } \\
\text { tax rates }\end{array}$} & $(2)$ & (3) & \multirow{3}{*}{$\begin{array}{c}\text { (4) } \\
\text { Building } \\
\text { investment }\end{array}$} & \multirow{3}{*}{$\begin{array}{c}(5) \\
\text { Admin. } \\
\text { grants }\end{array}$} & \multirow{3}{*}{$\begin{array}{c}\quad(6) \\
\text { Invest. } \\
\text { grants }\end{array}$} \\
\hline & & \multicolumn{2}{|c|}{ Current account } & & & \\
\hline & & Expend. & Revenues & & & \\
\hline Local post-election year & $\begin{array}{c}-0.046 * * \\
(0.011) \\
{[0.000]}\end{array}$ & $\begin{array}{c}-0.096 * * \\
(0.015) \\
{[0.000]}\end{array}$ & $\begin{array}{c}-0.058 * * \\
(0.016) \\
{[0.002]}\end{array}$ & $\begin{array}{c}-0.018 \\
(0.025) \\
{[1.000]}\end{array}$ & $\begin{array}{c}-0.008 \\
(0.016) \\
{[1.000]}\end{array}$ & $\begin{array}{c}0.031 \\
(0.029) \\
{[1.000]}\end{array}$ \\
\hline Local election year & $\begin{array}{c}-0.090 * * \\
(0.011) \\
{[0.000]}\end{array}$ & $\begin{array}{c}-0.043 * \\
(0.014) \\
{[0.012]}\end{array}$ & $\begin{array}{c}-0.080 * * \\
(0.016) \\
{[0.000]}\end{array}$ & $\begin{array}{l}0.086 * * \\
(0.026) \\
{[0.005]}\end{array}$ & $\begin{array}{c}-0.020 \\
(0.015) \\
{[0.990]}\end{array}$ & $\begin{array}{c}0.071+ \\
(0.029) \\
{[0.088]}\end{array}$ \\
\hline Local pre-election year & $\begin{array}{l}0.006 \\
(0.011) \\
{[1.000]}\end{array}$ & $\begin{array}{c}-0.013 \\
(0.014) \\
{[1.000]}\end{array}$ & $\begin{array}{c}-0.057 * * \\
(0.017) \\
{[0.003]}\end{array}$ & $\begin{array}{l}0.093 * * \\
(0.023) \\
{[0.000]}\end{array}$ & $\begin{array}{c}-0.060 * * \\
(0.016) \\
{[0.001]}\end{array}$ & $\begin{array}{l}0.104 * * \\
(0.030) \\
{[0.004]}\end{array}$ \\
\hline State post-election year & $\begin{array}{c}-0.035 * * \\
(0.011) \\
{[0.006]}\end{array}$ & $\begin{array}{l}0.026 \\
(0.013) \\
{[0.290]}\end{array}$ & $\begin{array}{c}-0.009 \\
(0.014) \\
{[1.000]}\end{array}$ & $\begin{array}{l}0.073 * * \\
(0.022) \\
{[0.006]}\end{array}$ & $\begin{array}{c}0.006 \\
(0.015) \\
{[1.000]}\end{array}$ & $\begin{array}{c}-0.012 \\
(0.024) \\
{[1.000]}\end{array}$ \\
\hline State election year & $\begin{array}{c}-0.045 * * \\
(0.012) \\
{[0.002]}\end{array}$ & $\begin{array}{c}0.059 * * \\
(0.015) \\
{[0.000]}\end{array}$ & $\begin{array}{c}0.005 \\
(0.016) \\
{[1.000]}\end{array}$ & $\begin{array}{c}0.057 \\
(0.027) \\
{[0.192]}\end{array}$ & $\begin{array}{c}-0.024 \\
(0.017) \\
{[0.947]}\end{array}$ & $\begin{array}{c}0.071+ \\
(0.028) \\
{[0.064]}\end{array}$ \\
\hline State pre-election year & $\begin{array}{c}-0.002 \\
(0.009) \\
{[1.000]}\end{array}$ & $\begin{array}{c}0.065 * * \\
(0.013) \\
{[0.000]}\end{array}$ & $\begin{array}{l}0.041 * \\
(0.014) \\
{[0.018]}\end{array}$ & $\begin{array}{c}0.019 \\
(0.022) \\
{[1.000]}\end{array}$ & $\begin{array}{c}0.013 \\
(0.015) \\
{[1.000]}\end{array}$ & $\begin{array}{c}0.022 \\
(0.029) \\
{[1.000]}\end{array}$ \\
\hline $\begin{array}{l}\text { MOV in state elections } \times \\
\text { local post-election year }\end{array}$ & $\begin{array}{c}-0.043 \\
(0.063) \\
{[1.000]}\end{array}$ & $\begin{array}{l}0.244 * \\
(0.078) \\
{[0.011]}\end{array}$ & $\begin{array}{c}0.062 \\
(0.081) \\
{[1.000]}\end{array}$ & $\begin{array}{l}0.193 \\
(0.140) \\
{[1.000]}\end{array}$ & $\begin{array}{c}0.003 \\
(0.083) \\
{[1.000]}\end{array}$ & $\begin{array}{c}0.177 \\
(0.178) \\
{[1.000]}\end{array}$ \\
\hline $\begin{array}{l}\text { MOV in state elections } \times \\
\text { local election year }\end{array}$ & $\begin{array}{l}0.200 * * \\
(0.058) \\
{[0.003]}\end{array}$ & $\begin{array}{l}0.247 * * \\
(0.074) \\
{[0.005]}\end{array}$ & $\begin{array}{c}0.172 \\
(0.080) \\
{[0.186]}\end{array}$ & $\begin{array}{c}-0.075 \\
(0.139) \\
{[1.000]}\end{array}$ & $\begin{array}{l}0.056 \\
(0.078) \\
{[1.000]}\end{array}$ & $\begin{array}{c}0.265 \\
(0.181) \\
{[0.867]}\end{array}$ \\
\hline $\begin{array}{l}\text { MOV in state elections } \times \\
\text { local pre-election year }\end{array}$ & $\begin{array}{c}0.114 \\
(0.052) \\
{[0.171]}\end{array}$ & $\begin{array}{l}0.094 \\
(0.063) \\
{[0.821]}\end{array}$ & $\begin{array}{l}0.128 \\
(0.070) \\
{[0.398]}\end{array}$ & $\begin{array}{l}0.001 \\
(0.105) \\
{[1.000]}\end{array}$ & $\begin{array}{l}0.096 \\
(0.072) \\
{[1.000]}\end{array}$ & $\begin{array}{c}0.039 \\
(0.165) \\
{[1.000]}\end{array}$ \\
\hline $\begin{array}{l}\text { MOV in state elections } \times \\
\text { state post-election year }\end{array}$ & $\begin{array}{c}0.134 \\
(0.063) \\
{[0.204]}\end{array}$ & $\begin{array}{c}-0.052 \\
(0.065) \\
{[1.000]}\end{array}$ & $\begin{array}{c}-0.040 \\
(0.068) \\
{[1.000]}\end{array}$ & $\begin{array}{c}-0.069 \\
(0.110) \\
{[1.000]}\end{array}$ & $\begin{array}{c}-0.162 \\
(0.072) \\
{[0.138]}\end{array}$ & $\begin{array}{c}0.212 \\
(0.119) \\
{[0.450]}\end{array}$ \\
\hline $\begin{array}{l}\text { MOV in state elections } \times \\
\text { state election year }\end{array}$ & $\begin{array}{l}0.197 * \\
(0.073) \\
{[0.040]}\end{array}$ & $\begin{array}{c}-0.008 \\
(0.080) \\
{[1.000]}\end{array}$ & $\begin{array}{c}-0.048 \\
(0.076) \\
{[1.000]}\end{array}$ & $\begin{array}{c}0.094 \\
(0.137) \\
{[1.000]}\end{array}$ & $\begin{array}{c}0.047 \\
(0.089) \\
{[1.000]}\end{array}$ & $\begin{array}{c}0.209 \\
(0.158) \\
{[1.000]}\end{array}$ \\
\hline $\begin{array}{l}\text { MOV in state elections } \times \\
\text { state pre-election year }\end{array}$ & $\begin{array}{c}0.005 \\
(0.045) \\
{[1.000]}\end{array}$ & $\begin{array}{r}-0.190 * \\
(0.061) \\
{[0.010]}\end{array}$ & $\begin{array}{c}-0.010 \\
(0.068) \\
{[1.000]}\end{array}$ & $\begin{array}{c}0.012 \\
(0.122) \\
{[1.000]}\end{array}$ & $\begin{array}{c}0.018 \\
(0.072) \\
{[1.000]}\end{array}$ & $\begin{array}{c}-0.172 \\
(0.169) \\
{[1.000]}\end{array}$ \\
\hline $\begin{array}{l}\text { Margin of victory in past } \\
\text { state elections }\end{array}$ & $\begin{array}{c}-0.236 \\
(0.120) \\
{[0.293]}\end{array}$ & $\begin{array}{c}-0.020 \\
(0.117) \\
{[1.000]}\end{array}$ & $\begin{array}{c}0.168 \\
(0.113) \\
{[0.824]}\end{array}$ & $\begin{array}{c}0.151 \\
(0.164) \\
{[1.000]}\end{array}$ & $\begin{array}{c}0.239 \\
(0.132) \\
{[0.419]}\end{array}$ & $\begin{array}{c}0.477 * \\
(0.179) \\
{[0.046]}\end{array}$ \\
\hline No. observations & 13472 & 13260 & 13268 & 13227 & 13165 & 13198 \\
\hline No. municipalities & 551 & 548 & 547 & 549 & 551 & 548 \\
\hline
\end{tabular}

Notes: The models rely on standardized dependent variables, originally measured in constant Euro per capita, except for the tax rate which is the standardized first principal component of three local tax multipliers. All models control for local population and an indicator for directly elected mayors. The margin of victory (MOV) in past state elections measures the difference between the local vote shares for the two largest parties in the last state elections. The six equations are jointly estimated in a seemingly unrelated regression (SUR) framework, controlling for municipality and year fixed effects. Standard errors clustered at the municipality level are presented in parentheses. Bonferroni-adjusted p-values (adjusted for multiple variable testing) are reported in square brackets. $+/ * / * *$ denote significance at the $10 / 5 / 1 \%$ level, adjusted for multiple variable testing. 
Table 6: State partisanship and cycles (SUR w. mun./year FE)

\begin{tabular}{|c|c|c|c|c|c|c|}
\hline \multirow{3}{*}{ Dependent variable } & (1) & $(2)$ & (3) & \multirow{3}{*}{$\begin{array}{c}(4) \\
\text { Building } \\
\text { investment }\end{array}$} & \multirow{3}{*}{$\begin{array}{c}\text { (5) } \\
\text { Admin. } \\
\text { grants }\end{array}$} & \multirow{3}{*}{$\begin{array}{c}\quad(6) \\
\text { Invest. } \\
\text { grants }\end{array}$} \\
\hline & Local & \multicolumn{2}{|c|}{ Current account } & & & \\
\hline & tax rates & Expend. & Revenues & & & \\
\hline Local post-election year & $\begin{array}{c}-0.035 * * \\
(0.008) \\
{[0.000]}\end{array}$ & $\begin{array}{c}-0.033+ \\
(0.013) \\
{[0.087]}\end{array}$ & $\begin{array}{c}-0.035+ \\
(0.014) \\
{[0.075]}\end{array}$ & $\begin{array}{c}-0.043 \\
(0.022) \\
{[0.295]}\end{array}$ & $\begin{array}{c}0.022 \\
(0.013) \\
{[0.597]}\end{array}$ & $\begin{array}{c}-0.030 \\
(0.025) \\
{[1.000]}\end{array}$ \\
\hline Local election year & $\begin{array}{c}-0.052 * * \\
(0.009) \\
{[0.000]}\end{array}$ & $\begin{array}{c}-0.023 \\
(0.015) \\
{[0.808]}\end{array}$ & $\begin{array}{c}-0.004 \\
(0.015) \\
{[1.000]}\end{array}$ & $\begin{array}{c}0.064+ \\
(0.025) \\
{[0.063]}\end{array}$ & $\begin{array}{c}-0.025 \\
(0.013) \\
{[0.301]}\end{array}$ & $\begin{array}{l}0.100 * * \\
(0.027) \\
{[0.001]}\end{array}$ \\
\hline Local pre-election year & $\begin{array}{c}-0.006 \\
(0.007) \\
{[1.000]}\end{array}$ & $\begin{array}{l}0.006 \\
(0.013) \\
{[1.000]}\end{array}$ & $\begin{array}{r}-0.017 \\
(0.015) \\
{[1.000]}\end{array}$ & $\begin{array}{l}0.077 * * \\
(0.023) \\
{[0.004]}\end{array}$ & $\begin{array}{c}-0.022 \\
(0.011) \\
{[0.352]}\end{array}$ & $\begin{array}{l}0.118 * * \\
(0.027) \\
{[0.000]}\end{array}$ \\
\hline State post-election year & $\begin{array}{c}0.021 \\
(0.012) \\
{[0.495]}\end{array}$ & $\begin{array}{l}0.013 \\
(0.015) \\
{[1.000]}\end{array}$ & $\begin{array}{c}0.049 * \\
(0.016) \\
{[0.014]}\end{array}$ & $\begin{array}{c}0.109 * * \\
(0.021) \\
{[0.000]}\end{array}$ & $\begin{array}{l}0.016 \\
(0.015) \\
{[1.000]}\end{array}$ & $\begin{array}{c}0.041 \\
(0.025) \\
{[0.596]}\end{array}$ \\
\hline State election year & $\begin{array}{c}-0.024 * \\
(0.008) \\
{[0.013]}\end{array}$ & $\begin{array}{c}0.072 * * \\
(0.013) \\
{[0.000]}\end{array}$ & $\begin{array}{c}0.018 \\
(0.012) \\
{[0.804]}\end{array}$ & $\begin{array}{c}0.093 * * \\
(0.022) \\
{[0.000]}\end{array}$ & $\begin{array}{c}0.032 * \\
(0.011) \\
{[0.030]}\end{array}$ & $\begin{array}{c}0.040 \\
(0.023) \\
{[0.476]}\end{array}$ \\
\hline State pre-election year & $\begin{array}{c}0.007 \\
(0.008) \\
{[1.000]}\end{array}$ & $\begin{array}{c}0.031+ \\
(0.013) \\
{[0.093]}\end{array}$ & $\begin{array}{l}0.057 * * \\
(0.013) \\
{[0.000]}\end{array}$ & $\begin{array}{c}0.047 \\
(0.020) \\
{[0.125]}\end{array}$ & $\begin{array}{c}0.031+ \\
(0.012) \\
{[0.055]}\end{array}$ & $\begin{array}{c}-0.013 \\
(0.022) \\
{[1.000]}\end{array}$ \\
\hline $\begin{array}{l}\text { Left state gov. } \times \\
\text { local post-election year }\end{array}$ & $\begin{array}{c}-0.109 * * \\
(0.013) \\
{[0.000]}\end{array}$ & $\begin{array}{c}-0.042 \\
(0.019) \\
{[0.185]}\end{array}$ & $\begin{array}{c}-0.069 * * \\
(0.020) \\
{[0.005]}\end{array}$ & $\begin{array}{c}0.075+ \\
(0.030) \\
{[0.081]}\end{array}$ & $\begin{array}{c}-0.045 \\
(0.019) \\
{[0.121]}\end{array}$ & $\begin{array}{l}0.149 * * \\
(0.035) \\
{[0.000]}\end{array}$ \\
\hline $\begin{array}{l}\text { Left state gov. } \times \\
\text { local election year }\end{array}$ & $\begin{array}{c}-0.006 \\
(0.015) \\
{[1.000]}\end{array}$ & $\begin{array}{c}0.013 \\
(0.020) \\
{[1.000]}\end{array}$ & $\begin{array}{c}-0.095 * * \\
(0.020) \\
{[0.000]}\end{array}$ & $\begin{array}{c}0.002 \\
(0.034) \\
{[1.000]}\end{array}$ & $\begin{array}{c}-0.011 \\
(0.019) \\
{[1.000]}\end{array}$ & $\begin{array}{c}0.009 \\
(0.038) \\
{[1.000]}\end{array}$ \\
\hline $\begin{array}{l}\text { Left state gov. } \times \\
\text { local pre-election year }\end{array}$ & $\begin{array}{l}0.114 * * \\
(0.012) \\
{[0.000]}\end{array}$ & $\begin{array}{c}0.039+ \\
(0.016) \\
{[0.099]}\end{array}$ & $\begin{array}{c}-0.017 \\
(0.018) \\
{[1.000]}\end{array}$ & $\begin{array}{c}-0.000 \\
(0.030) \\
{[1.000]}\end{array}$ & $\begin{array}{c}-0.039 \\
(0.017) \\
{[0.119]}\end{array}$ & $\begin{array}{c}-0.051 \\
(0.034) \\
{[0.765]}\end{array}$ \\
\hline $\begin{array}{l}\text { Left state gov. } \times \\
\text { state post-election year }\end{array}$ & $\begin{array}{c}-0.005 \\
(0.013) \\
{[1.000]}\end{array}$ & $\begin{array}{l}0.016 \\
(0.017) \\
{[1.000]}\end{array}$ & $\begin{array}{c}-0.076 * * \\
(0.020) \\
{[0.001]}\end{array}$ & $\begin{array}{c}-0.050 \\
(0.030) \\
{[0.562]}\end{array}$ & $\begin{array}{c}-0.078 * * \\
(0.017) \\
{[0.000]}\end{array}$ & $\begin{array}{c}-0.009 \\
(0.032) \\
{[1.000]}\end{array}$ \\
\hline $\begin{array}{l}\text { Left state gov. } \times \\
\text { state election year }\end{array}$ & $\begin{array}{c}0.153 * * \\
(0.013) \\
{[0.000]}\end{array}$ & $\begin{array}{c}0.020 \\
(0.018) \\
{[1.000]}\end{array}$ & $\begin{array}{l}0.020 \\
(0.018) \\
{[1.000]}\end{array}$ & $\begin{array}{c}-0.061 \\
(0.033) \\
{[0.378]}\end{array}$ & $\begin{array}{c}-0.091 * * \\
(0.019) \\
{[0.000]}\end{array}$ & $\begin{array}{c}0.045 \\
(0.035) \\
{[1.000]}\end{array}$ \\
\hline $\begin{array}{l}\text { Left state gov. } \times \\
\text { state pre-election year }\end{array}$ & $\begin{array}{l}0.096 * * \\
(0.011) \\
{[0.000]}\end{array}$ & $\begin{array}{c}0.030 \\
(0.017) \\
{[0.514]}\end{array}$ & $\begin{array}{c}0.022 \\
(0.018) \\
{[1.000]}\end{array}$ & $\begin{array}{c}-0.044 \\
(0.029) \\
{[0.769]}\end{array}$ & $\begin{array}{c}-0.045 * \\
(0.017) \\
{[0.048]}\end{array}$ & $\begin{array}{c}0.025 \\
(0.032) \\
{[1.000]}\end{array}$ \\
\hline Left state gov. & $\begin{array}{c}-0.226 * * \\
(0.034) \\
{[0.000]}\end{array}$ & $\begin{array}{c}-0.148 * * \\
(0.033) \\
{[0.000]}\end{array}$ & $\begin{array}{c}-0.039 \\
(0.034) \\
{[1.000]}\end{array}$ & $\begin{array}{c}-0.094 \\
(0.042) \\
{[0.164]}\end{array}$ & $\begin{array}{c}0.101 * \\
(0.035) \\
{[0.024]}\end{array}$ & $\begin{array}{c}-0.053 \\
(0.043) \\
{[1.000]}\end{array}$ \\
\hline No. observations & 15775 & 15506 & 15516 & 15474 & 15349 & 15444 \\
\hline No. municipalities & 597 & 593 & 593 & 595 & 597 & 595 \\
\hline
\end{tabular}

Notes: The models rely on standardized dependent variables, originally measured in constant Euro per capita, except for the tax rate which is the standardized first principal component of three local tax multipliers. All models control for local population and an indicator for directly elected mayors. The left state government variable takes 1 if in the previous year SPD, the major leftist party was part of the state government. The six equations are jointly estimated in a seemingly unrelated regression (SUR) framework, controlling for municipality and year fixed effects. Standard errors clustered at the municipality level are presented in parentheses. Bonferroni-adjusted pvalues (adjusted for multiple variable testing) are reported in square brackets. $+/ * / * *$ denote significance at the $10 / 5 / 1 \%$ level, adjusted for multiple variable testing. 
Table 7: Local partisanship and cycles (SUR w. mun./year FE)

\begin{tabular}{|c|c|c|c|c|c|c|}
\hline \multirow{3}{*}{ Dependent variable } & (1) & (2) & (3) & \multirow{3}{*}{$\begin{array}{c}\text { (4) } \\
\text { Building } \\
\text { investment }\end{array}$} & \multirow{3}{*}{$\begin{array}{c}\text { (5) } \\
\text { Admin. } \\
\text { grants }\end{array}$} & \multirow{3}{*}{$\begin{array}{c}\text { (6) } \\
\text { Invest. } \\
\text { grants }\end{array}$} \\
\hline & Local & \multicolumn{2}{|c|}{ Current account } & & & \\
\hline & tax rates & Expend. & Revenues & & & \\
\hline Local post-election year & $\begin{array}{c}-0.011 \\
(0.006) \\
{[0.467]}\end{array}$ & $\begin{array}{c}-0.030 * * \\
(0.009) \\
{[0.008]}\end{array}$ & $\begin{array}{c}-0.050 * * \\
(0.010) \\
{[0.000]}\end{array}$ & $\begin{array}{c}-0.021 \\
(0.018) \\
{[1.000]}\end{array}$ & $\begin{array}{r}-0.017 \\
(0.010) \\
{[0.581]}\end{array}$ & $\begin{array}{c}0.043 \\
(0.019) \\
{[0.158]}\end{array}$ \\
\hline Local election year & $\begin{array}{c}-0.070 * * \\
(0.007) \\
{[0.000]}\end{array}$ & $\begin{array}{c}-0.016 \\
(0.010) \\
{[0.668]}\end{array}$ & $\begin{array}{c}-0.057 * * \\
(0.012) \\
{[0.000]}\end{array}$ & $\begin{array}{c}0.055+ \\
(0.022) \\
{[0.066]}\end{array}$ & $\begin{array}{c}-0.030 * \\
(0.011) \\
{[0.030]}\end{array}$ & $\begin{array}{l}0.088 * * \\
(0.022) \\
{[0.000]}\end{array}$ \\
\hline Local pre-election year & $\begin{array}{c}0.008 \\
(0.007) \\
{[1.000]}\end{array}$ & $\begin{array}{c}0.009 \\
(0.010) \\
{[1.000]}\end{array}$ & $\begin{array}{c}-0.036 * * \\
(0.011) \\
{[0.005]}\end{array}$ & $\begin{array}{l}0.090 * * \\
(0.018) \\
{[0.000]}\end{array}$ & $\begin{array}{c}-0.038 * * \\
(0.011) \\
{[0.005]}\end{array}$ & $\begin{array}{l}0.084 * * \\
(0.020) \\
{[0.000]}\end{array}$ \\
\hline State post-election year & $\begin{array}{c}-0.015 * \\
(0.006) \\
{[0.040]}\end{array}$ & $\begin{array}{c}0.003 \\
(0.008) \\
{[1.000]}\end{array}$ & $\begin{array}{c}-0.011 \\
(0.010) \\
{[1.000]}\end{array}$ & $\begin{array}{l}0.059 * * \\
(0.015) \\
{[0.000]}\end{array}$ & $\begin{array}{c}-0.011 \\
(0.010) \\
{[1.000]}\end{array}$ & $\begin{array}{c}0.005 \\
(0.017) \\
{[1.000]}\end{array}$ \\
\hline State election year & $\begin{array}{c}-0.026 * * \\
(0.007) \\
{[0.001]}\end{array}$ & $\begin{array}{l}0.054 * * \\
(0.009) \\
{[0.000]}\end{array}$ & $\begin{array}{c}0.005 \\
(0.010) \\
{[1.000]}\end{array}$ & $\begin{array}{l}0.091 * * \\
(0.018) \\
{[0.000]}\end{array}$ & $\begin{array}{c}-0.012 \\
(0.011) \\
{[1.000]}\end{array}$ & $\begin{array}{l}0.099 * * \\
(0.019) \\
{[0.000]}\end{array}$ \\
\hline State pre-election year & $\begin{array}{c}-0.033 * * \\
(0.006) \\
{[0.000]}\end{array}$ & $\begin{array}{c}0.020 \\
(0.009) \\
{[0.135]}\end{array}$ & $\begin{array}{c}0.021 \\
(0.010) \\
{[0.164]}\end{array}$ & $\begin{array}{l}0.056 * * \\
(0.016) \\
{[0.003]}\end{array}$ & $\begin{array}{l}0.037 * * \\
(0.010) \\
{[0.003]}\end{array}$ & $\begin{array}{c}-0.006 \\
(0.018) \\
{[1.000]}\end{array}$ \\
\hline $\begin{array}{l}\text { Left local gov. } \times \\
\text { local post-election year }\end{array}$ & $\begin{array}{c}-0.071 * * \\
(0.013) \\
{[0.000]}\end{array}$ & $\begin{array}{c}-0.033 \\
(0.017) \\
{[0.323]}\end{array}$ & $\begin{array}{c}0.013 \\
(0.018) \\
{[1.000]}\end{array}$ & $\begin{array}{c}0.049 \\
(0.027) \\
{[0.435]}\end{array}$ & $\begin{array}{c}0.003 \\
(0.018) \\
{[1.000]}\end{array}$ & $\begin{array}{c}0.047 \\
(0.034) \\
{[0.982]}\end{array}$ \\
\hline $\begin{array}{l}\text { Left local gov. } \times \\
\text { local election year }\end{array}$ & $\begin{array}{c}-0.029 \\
(0.013) \\
{[0.137]}\end{array}$ & $\begin{array}{c}-0.034 \\
(0.019) \\
{[0.427]}\end{array}$ & $\begin{array}{r}-0.017 \\
(0.018) \\
{[1.000]}\end{array}$ & $\begin{array}{c}0.008 \\
(0.032) \\
{[1.000]}\end{array}$ & $\begin{array}{c}0.046 \\
(0.020) \\
{[0.116]}\end{array}$ & $\begin{array}{c}0.007 \\
(0.036) \\
{[1.000]}\end{array}$ \\
\hline $\begin{array}{l}\text { Left local gov. } \times \\
\text { local pre-election year }\end{array}$ & $\begin{array}{c}0.021 \\
(0.011) \\
{[0.290]}\end{array}$ & $\begin{array}{c}-0.014 \\
(0.015) \\
{[1.000]}\end{array}$ & $\begin{array}{c}-0.018 \\
(0.017) \\
{[1.000]}\end{array}$ & $\begin{array}{c}-0.067 * \\
(0.025) \\
{[0.042]}\end{array}$ & $\begin{array}{c}0.031 \\
(0.019) \\
{[0.594]}\end{array}$ & $\begin{array}{c}-0.050 \\
(0.030) \\
{[0.550]}\end{array}$ \\
\hline $\begin{array}{l}\text { Left local gov. } \times \\
\text { state post-election year }\end{array}$ & $\begin{array}{c}-0.003 \\
(0.011) \\
{[1.000]}\end{array}$ & $\begin{array}{c}0.002 \\
(0.016) \\
{[1.000]}\end{array}$ & $\begin{array}{c}0.006 \\
(0.015) \\
{[1.000]}\end{array}$ & $\begin{array}{c}0.011 \\
(0.023) \\
{[1.000]}\end{array}$ & $\begin{array}{c}-0.026 \\
(0.016) \\
{[0.688]}\end{array}$ & $\begin{array}{c}0.063 \\
(0.028) \\
{[0.153]}\end{array}$ \\
\hline $\begin{array}{l}\text { Left local gov. } \times \\
\text { state election year }\end{array}$ & $\begin{array}{c}0.035+ \\
(0.013) \\
{[0.051]}\end{array}$ & $\begin{array}{c}-0.009 \\
(0.019) \\
{[1.000]}\end{array}$ & $\begin{array}{c}-0.016 \\
(0.018) \\
{[1.000]}\end{array}$ & $\begin{array}{c}-0.076 \\
(0.032) \\
{[0.102]}\end{array}$ & $\begin{array}{c}-0.011 \\
(0.020) \\
{[1.000]}\end{array}$ & $\begin{array}{c}-0.061 \\
(0.033) \\
{[0.384]}\end{array}$ \\
\hline $\begin{array}{l}\text { Left local gov. } \times \\
\text { state pre-election year }\end{array}$ & $\begin{array}{l}0.059 * * \\
(0.011) \\
{[0.000]}\end{array}$ & $\begin{array}{c}0.004 \\
(0.018) \\
{[1.000]}\end{array}$ & $\begin{array}{l}0.029 \\
(0.018) \\
{[0.695]}\end{array}$ & $\begin{array}{c}-0.103 * * \\
(0.026) \\
{[0.000]}\end{array}$ & $\begin{array}{c}-0.035 \\
(0.018) \\
{[0.361]}\end{array}$ & $\begin{array}{c}0.009 \\
(0.033) \\
{[1.000]}\end{array}$ \\
\hline Left local gov. & $\begin{array}{c}-0.052 \\
(0.030) \\
{[0.501]}\end{array}$ & $\begin{array}{c}-0.062 \\
(0.031) \\
{[0.252]}\end{array}$ & $\begin{array}{c}0.053 \\
(0.029) \\
{[0.414]}\end{array}$ & $\begin{array}{c}0.027 \\
(0.038) \\
{[1.000]}\end{array}$ & $\begin{array}{c}-0.098 * \\
(0.032) \\
{[0.012]}\end{array}$ & $\begin{array}{c}0.007 \\
(0.037) \\
{[1.000]}\end{array}$ \\
\hline No. observations & 15046 & 14806 & 14816 & 14758 & 14628 & 14746 \\
\hline No. municipalities & 580 & 578 & 577 & 580 & 580 & 579 \\
\hline
\end{tabular}

Notes: The models rely on standardized dependent variables, originally measured in constant Euro per capita, except for the tax rate which is the standardized first principal component of three local tax multipliers. All models control for local population and an indicator for directly elected mayors. The left local government variable takes 1 if in the previous year SPD, the major leftist party received the most seats among the major parties in the local government. The six equations are jointly estimated in a seemingly unrelated regression (SUR) framework, controlling for municipality and year fixed effects. Standard errors clustered at the municipality level are presented in parentheses. Bonferroni-adjusted p-values (adjusted for multiple variable testing) are reported in square brackets. $+/ * / * *$ denote significance at the $10 / 5 / 1 \%$ level, adjusted for multiple variable testing. 
Table 8: Robustness: Alternative election year indicators (SUR w. mun./year FE)

\begin{tabular}{lcccccc}
\hline & $(1)$ & $(2)$ & $(3)$ & $(4)$ & $(5)$ & $(6)$ \\
Lependent variable & $\begin{array}{c}\text { Local } \\
\text { tax rates }\end{array}$ & $\begin{array}{c}\text { Current } \\
\text { Expend. }\end{array}$ & $\begin{array}{c}\text { Revent } \\
\text { Revesues }\end{array}$ & $\begin{array}{c}\text { Building } \\
\text { investment }\end{array}$ & $\begin{array}{c}\text { Admin. } \\
\text { grants }\end{array}$ & $\begin{array}{c}\text { Invest. } \\
\text { grants }\end{array}$ \\
\hline Local post-election year (alt.) & $-0.115 * *$ & $-0.061 * *$ & $-0.050 * *$ & 0.009 & -0.010 & $0.088 * *$ \\
& $(0.008)$ & $(0.010)$ & $(0.012)$ & $(0.018)$ & $(0.010)$ & $(0.020)$ \\
& {$[0.000]$} & {$[0.000]$} & {$[0.000]$} & {$[1.000]$} & {$[1.000]$} & {$[0.000]$} \\
Local pre-election year (alt.) & $-0.018 *$ & 0.017 & $-0.036 *$ & $0.125 * *$ & $-0.034 * *$ & $0.113 * *$ \\
& $(0.006)$ & $(0.011)$ & $(0.012)$ & $(0.019)$ & $(0.010)$ & $(0.022)$ \\
State post-election year (alt.) & {$[0.027]$} & {$[0.645]$} & {$[0.022]$} & {$[0.000]$} & {$[0.004]$} & {$[0.000]$} \\
& $-0.025 * *$ & $0.035 * *$ & -0.008 & $0.079 * *$ & -0.014 & $0.078 * *$ \\
State pre-election year & $(0.005)$ & $(0.009)$ & $(0.010)$ & $(0.016)$ & $(0.010)$ & $(0.017)$ \\
& {$[0.000]$} & {$[0.001]$} & {$[1.000]$} & {$[0.000]$} & {$[1.000]$} & {$[0.000]$} \\
& -0.012 & $0.050 * *$ & 0.022 & 0.006 & 0.011 & 0.035 \\
& $(0.005)$ & $(0.008)$ & $(0.009)$ & $(0.015)$ & $(0.009)$ & $(0.017)$ \\
No. observations & {$[0.130]$} & {$[0.000]$} & {$[0.125]$} & {$[1.000]$} & {$[1.000]$} & {$[0.249]$} \\
No. municipalities & 16378 & 16103 & 16101 & 16084 & 15971 & 16043 \\
& 604 & 601 & 599 & 602 & 604 & 601
\end{tabular}

Notes: The models rely on standardized dependent variables, originally measured in constant Euro per capita, except for the tax rate which is the standardized first principal component of three local tax multipliers. All models control for local population and an indicator for directly elected mayors. The alternative pre-election/post-election year indicators measure the share of the current year that coincided with the 12 months before/after local or state elections. The six equations are jointly estimated in a seemingly unrelated regression (SUR) framework, controlling for municipality and year fixed effects. Standard errors clustered at the municipality level are presented in parentheses. Bonferroni-adjusted p-values (adjusted for multiple variable testing) are reported in square brackets. $+/ * / * *$ denote significance at the $10 / 5 / 1 \%$ level, adjusted for multiple variable testing. 
Table 9: Robustness: Full cycle (SUR w. mun./year FE)

\begin{tabular}{|c|c|c|c|c|c|c|}
\hline \multirow{3}{*}{ Dependent variable } & (1) & $(2)$ & $(3)$ & \multirow{3}{*}{$\begin{array}{c}(4) \\
\text { Building } \\
\text { investment }\end{array}$} & \multirow{3}{*}{$\begin{array}{c}\text { (5) } \\
\text { Admin. } \\
\text { grants }\end{array}$} & \multirow{3}{*}{$\begin{array}{c}\text { (6) } \\
\text { Invest. } \\
\text { grants }\end{array}$} \\
\hline & Local & \multicolumn{2}{|c|}{ Current account } & & & \\
\hline & tax rates & Expend. & Revenues & & & \\
\hline Local election year $(t)$ & $\begin{array}{c}-0.097 * * \\
(0.008) \\
{[0.000]}\end{array}$ & $\begin{array}{c}-0.018 \\
(0.011) \\
{[0.639]}\end{array}$ & $\begin{array}{c}-0.024 \\
(0.013) \\
{[0.361]}\end{array}$ & $\begin{array}{l}0.099 * * \\
(0.018) \\
{[0.000]}\end{array}$ & $\begin{array}{c}-0.017 \\
(0.011) \\
{[0.659]}\end{array}$ & $\begin{array}{l}0.077 * * \\
(0.022) \\
{[0.002]}\end{array}$ \\
\hline Local election $(t-1)$ & $\begin{array}{l}0.033 * * \\
(0.007) \\
{[0.000]}\end{array}$ & $\begin{array}{c}0.022 \\
(0.012) \\
{[0.378]}\end{array}$ & $\begin{array}{c}0.013 \\
(0.013) \\
{[1.000]}\end{array}$ & $\begin{array}{l}0.107 * * \\
(0.020) \\
{[0.000]}\end{array}$ & $\begin{array}{c}-0.025 \\
(0.011) \\
{[0.132]}\end{array}$ & $\begin{array}{c}0.040 \\
(0.023) \\
{[0.499]}\end{array}$ \\
\hline Local election $(t-2)$ & $\begin{array}{l}0.045 * * \\
(0.007) \\
{[0.000]}\end{array}$ & $\begin{array}{c}0.037 * \\
(0.012) \\
{[0.012]}\end{array}$ & $\begin{array}{l}0.036 * * \\
(0.011) \\
{[0.009]}\end{array}$ & $\begin{array}{c}0.048+ \\
(0.020) \\
{[0.095]}\end{array}$ & $\begin{array}{c}-0.028+ \\
(0.011) \\
{[0.055]}\end{array}$ & $\begin{array}{c}-0.040 \\
(0.022) \\
{[0.446]}\end{array}$ \\
\hline Local election $(t-3)$ & $\begin{array}{c}0.001 \\
(0.008) \\
{[1.000]}\end{array}$ & $\begin{array}{c}0.004 \\
(0.012) \\
{[1.000]}\end{array}$ & $\begin{array}{l}0.072 * * \\
(0.012) \\
{[0.000]}\end{array}$ & $\begin{array}{c}0.059 * \\
(0.019) \\
{[0.013]}\end{array}$ & $\begin{array}{l}0.027+ \\
(0.011) \\
{[0.075]}\end{array}$ & $\begin{array}{c}-0.015 \\
(0.021) \\
{[1.000]}\end{array}$ \\
\hline State election year $(t)$ & $\begin{array}{c}0.013 \\
(0.008) \\
{[0.691]}\end{array}$ & $\begin{array}{l}0.066 * * \\
(0.012) \\
{[0.000]}\end{array}$ & $\begin{array}{l}0.069 * * \\
(0.012) \\
{[0.000]}\end{array}$ & $\begin{array}{l}0.101 * * \\
(0.017) \\
{[0.000]}\end{array}$ & $\begin{array}{l}0.062 * * \\
(0.012) \\
{[0.000]}\end{array}$ & $\begin{array}{c}0.058 * \\
(0.019) \\
{[0.012]}\end{array}$ \\
\hline State election $(t-1)$ & $\begin{array}{l}0.065 * * \\
(0.009) \\
{[0.000]}\end{array}$ & $\begin{array}{l}0.059 * * \\
(0.011) \\
{[0.000]}\end{array}$ & $\begin{array}{l}0.094 * * \\
(0.014) \\
{[0.000]}\end{array}$ & $\begin{array}{c}0.036 \\
(0.019) \\
{[0.314]}\end{array}$ & $\begin{array}{l}0.076 * * \\
(0.013) \\
{[0.000]}\end{array}$ & $\begin{array}{c}-0.024 \\
(0.022) \\
{[1.000]}\end{array}$ \\
\hline State election $(t-2)$ & $\begin{array}{l}0.076 * * \\
(0.009) \\
{[0.000]}\end{array}$ & $\begin{array}{c}0.038 * \\
(0.013) \\
{[0.017]}\end{array}$ & $\begin{array}{l}0.076 * * \\
(0.015) \\
{[0.000]}\end{array}$ & $\begin{array}{c}0.025 \\
(0.019) \\
{[1.000]}\end{array}$ & $\begin{array}{c}0.057 * * \\
(0.014) \\
{[0.000]}\end{array}$ & $\begin{array}{c}-0.019 \\
(0.023) \\
{[1.000]}\end{array}$ \\
\hline State election $(t-3)$ & $\begin{array}{l}0.070 * * \\
(0.009) \\
{[0.000]}\end{array}$ & $\begin{array}{l}0.040 * * \\
(0.012) \\
{[0.004]}\end{array}$ & $\begin{array}{l}0.073 * * \\
(0.013) \\
{[0.000]}\end{array}$ & $\begin{array}{l}0.053 * * \\
(0.016) \\
{[0.005]}\end{array}$ & $\begin{array}{l}0.096 * * \\
(0.012) \\
{[0.000]}\end{array}$ & $\begin{array}{c}-0.046 \\
(0.021) \\
{[0.184]}\end{array}$ \\
\hline & 16378 & 16103 & 16101 & 16084 & 15971 & 16043 \\
\hline No. municipalities & 604 & 601 & 599 & 602 & 604 & 601 \\
\hline
\end{tabular}

Notes: The models rely on standardized dependent variables, originally measured in constant Euro per capita, except for the tax rate which is the standardized first principal component of three local tax multipliers. All models control for local population and an indicator for directly elected mayors. The six equations are jointly estimated in a seemingly unrelated regression (SUR) framework, controlling for municipality and year fixed effects. Standard errors clustered at the municipality level are presented in parentheses. Bonferroni-adjusted p-values (adjusted for multiple variable testing) are reported in square brackets. $+/^{*} / * *$ denote significance at the $10 / 5 / 1 \%$ level, adjusted for multiple variable testing. 
Table 10: Robustness: Baseline cycle with state economic controls (SUR w. mun./year FE)

\begin{tabular}{|c|c|c|c|c|c|c|}
\hline \multirow{3}{*}{ Dependent variable } & (1) & (2) & (3) & \multirow{3}{*}{$\begin{array}{c}(4) \\
\text { Building } \\
\text { investment }\end{array}$} & \multirow{3}{*}{$\begin{array}{c}\text { (5) } \\
\text { Admin. } \\
\text { grants }\end{array}$} & \multirow{3}{*}{$\begin{array}{c}\quad(6) \\
\text { Invest. } \\
\text { grants }\end{array}$} \\
\hline & Local & \multicolumn{2}{|c|}{ Current account } & & & \\
\hline & tax rates & Expend. & Revenues & & & \\
\hline \multirow{3}{*}{ Local post-election year } & $-0.034 * *$ & $-0.048 * *$ & $-0.053 * *$ & -0.013 & -0.011 & 0.036 \\
\hline & $(0.005)$ & $(0.008)$ & $(0.009)$ & $(0.015)$ & $(0.009)$ & $(0.018)$ \\
\hline & {$[0.000]$} & {$[0.000]$} & {$[0.000]$} & {$[1.000]$} & [1.000] & {$[0.262]$} \\
\hline \multirow[t]{3}{*}{ Local election year } & $-0.072 * *$ & $-0.026 *$ & $-0.058 * *$ & $0.066 * *$ & -0.017 & $0.098 * *$ \\
\hline & $(0.006)$ & $(0.009)$ & $(0.010)$ & $(0.017)$ & $(0.008)$ & $(0.017)$ \\
\hline & {$[0.000]$} & {$[0.021]$} & {$[0.000]$} & {$[0.000]$} & {$[0.234]$} & {$[0.000]$} \\
\hline \multirow[t]{3}{*}{ Local pre-election year } & $0.060 * *$ & 0.018 & $-0.025+$ & $0.071 * *$ & $-0.024 *$ & $0.066 * *$ \\
\hline & $(0.006)$ & $(0.009)$ & $(0.010)$ & $(0.016)$ & $(0.009)$ & $(0.018)$ \\
\hline & {$[0.000]$} & {$[0.279]$} & {$[0.067]$} & {$[0.000]$} & {$[0.047]$} & {$[0.001]$} \\
\hline \multirow[t]{3}{*}{ State post-election year } & -0.007 & 0.003 & -0.006 & $0.045 * *$ & -0.008 & 0.003 \\
\hline & $(0.005)$ & $(0.008)$ & $(0.009)$ & $(0.013)$ & $(0.009)$ & $(0.015)$ \\
\hline & {$[0.648]$} & {$[1.000]$} & {$[1.000]$} & {$[0.003]$} & {$[1.000]$} & {$[1.000]$} \\
\hline \multirow[t]{3}{*}{ State election year } & $-0.025 * *$ & $0.045 * *$ & 0.010 & $0.077 * *$ & -0.004 & $0.081 * *$ \\
\hline & $(0.005)$ & $(0.008)$ & $(0.009)$ & $(0.015)$ & $(0.009)$ & $(0.016)$ \\
\hline & {$[0.000]$} & {$[0.000]$} & {$[1.000]$} & {$[0.000]$} & {$[1.000]$} & {$[0.000]$} \\
\hline \multirow[t]{3}{*}{ State pre-election year } & 0.004 & $0.032 * *$ & $0.040 * *$ & 0.023 & $0.015^{\circ}$ & 0.009 \\
\hline & $(0.004)$ & $(0.007)$ & $(0.008)$ & $(0.012)$ & $(0.008)$ & $(0.015)$ \\
\hline & [1.000] & {$[0.000]$} & {$[0.000]$} & {$[0.379]$} & {$[0.392]$} & [1.000] \\
\hline \multirow{3}{*}{$\begin{array}{l}\text { Lagged state unemployment } \\
\text { rate }\end{array}$} & $0.276 * *$ & $0.088 * *$ & $0.057 * *$ & $-0.134 * *$ & -0.009 & $-0.095 * *$ \\
\hline & $(0.010)$ & $(0.009)$ & $(0.009)$ & $(0.014)$ & $(0.010)$ & $(0.015)$ \\
\hline & {$[0.000]$} & {$[0.000]$} & {$[0.000]$} & {$[0.000]$} & {$[1.000]$} & {$[0.000]$} \\
\hline \multirow[t]{3}{*}{ Lagged state GDP pc. } & $-0.067 * *$ & $-0.033 * *$ & $0.022+$ & $-0.046 * *$ & $0.038 * *$ & $-0.045 * *$ \\
\hline & $(0.010)$ & $(0.008)$ & $(0.009)$ & $(0.011)$ & $(0.009)$ & $(0.012)$ \\
\hline & {$[0.000]$} & {$[0.000]$} & {$[0.073]$} & {$[0.000]$} & {$[0.000]$} & {$[0.001]$} \\
\hline \multirow{3}{*}{$\begin{array}{l}\text { Lagged state GDP } \\
\text { growth rate }\end{array}$} & $0.024 * *$ & 0.012 & $0.023 * *$ & $0.045 * *$ & 0.005 & $0.034 * *$ \\
\hline & $(0.004)$ & $(0.005)$ & $(0.006)$ & $(0.007)$ & $(0.005)$ & $(0.008)$ \\
\hline & {$[0.000]$} & {$[0.103]$} & {$[0.001]$} & {$[0.000]$} & {$[1.000]$} & {$[0.000]$} \\
\hline No. observations & 16378 & 16103 & 16101 & 16084 & 15971 & 16043 \\
\hline No. municipalities & 604 & 601 & 599 & 602 & 604 & 601 \\
\hline
\end{tabular}

Notes: The models rely on standardized dependent variables, originally measured in constant Euro per capita, except for the tax rate which is the standardized first principal component of three local tax multipliers. All models control for local population and an indicator for directly elected mayors. The six equations are jointly estimated in a seemingly unrelated regression (SUR) framework, controlling for municipality and year fixed effects. Standard errors clustered at the municipality level are presented in parentheses. Bonferroni-adjusted p-values (adjusted for multiple variable testing) are reported in square brackets. $+/^{*} / * *$ denote significance at the $10 / 5 / 1 \%$ level, adjusted for multiple variable testing. 
Table 11: Robustness: Baseline for tax multipliers (SUR w. mun./year FE)

\begin{tabular}{|c|c|c|c|c|c|}
\hline Dependent variable & $\begin{array}{c}(1) \\
\text { Composite local } \\
\text { tax rates }\end{array}$ & $\begin{array}{l}\text { Business tax } \\
\text { multiplier }\end{array}$ & $\begin{array}{c}(3) \\
\text { Agr. property } \\
\text { multiplier }\end{array}$ & $\begin{array}{c}(4) \\
\text { Nonagr. property } \\
\text { tax multiplier }\end{array}$ & $\begin{array}{c}(5) \\
\text { FD in local } \\
\text { tax rates }\end{array}$ \\
\hline Local post-election year & $\begin{array}{c}-0.068 * * \\
(0.005) \\
{[0.000]}\end{array}$ & $\begin{array}{c}-0.089 * * \\
(0.006) \\
{[0.000]}\end{array}$ & $\begin{array}{c}-0.024 * * \\
(0.005) \\
{[0.000]}\end{array}$ & $\begin{array}{c}-0.046 * * \\
(0.006) \\
{[0.000]}\end{array}$ & $\begin{array}{l}0.016 * * \\
(0.005) \\
{[0.009]}\end{array}$ \\
\hline Local election year & $\begin{array}{c}-0.103 * * \\
(0.007) \\
{[0.000]}\end{array}$ & $\begin{array}{c}-0.129 * * \\
(0.009) \\
{[0.000]}\end{array}$ & $\begin{array}{c}-0.043 * * \\
(0.005) \\
{[0.000]}\end{array}$ & $\begin{array}{c}-0.072 * * \\
(0.006) \\
{[0.000]}\end{array}$ & $\begin{array}{c}-0.043 * * \\
(0.004) \\
{[0.000]}\end{array}$ \\
\hline Local pre-election year & $\begin{array}{l}0.017 * \\
(0.006) \\
{[0.016]}\end{array}$ & $\begin{array}{l}0.028 * * \\
(0.006) \\
{[0.000]}\end{array}$ & $\begin{array}{r}-0.002 \\
(0.005) \\
{[1.000]}\end{array}$ & $\begin{array}{c}0.010 \\
(0.006) \\
{[0.359]}\end{array}$ & $\begin{array}{r}-0.001 \\
(0.005) \\
{[1.000]}\end{array}$ \\
\hline State post-election year & $\begin{array}{r}-0.004 \\
(0.005) \\
{[1.000]}\end{array}$ & $\begin{array}{c}0.009 \\
(0.005) \\
{[0.318]}\end{array}$ & $\begin{array}{c}-0.016 * * \\
(0.005) \\
{[0.003]}\end{array}$ & $\begin{array}{r}-0.007 \\
(0.005) \\
{[0.545]}\end{array}$ & $\begin{array}{c}-0.026 * * \\
(0.004) \\
{[0.000]}\end{array}$ \\
\hline State election year & $\begin{array}{c}-0.026 * * \\
(0.005) \\
{[0.000]}\end{array}$ & $\begin{array}{c}-0.018 * * \\
(0.005) \\
{[0.001]}\end{array}$ & $\begin{array}{c}-0.028 * * \\
(0.005) \\
{[0.000]}\end{array}$ & $\begin{array}{c}-0.023 * * \\
(0.005) \\
{[0.000]}\end{array}$ & $\begin{array}{c}-0.042 * * \\
(0.005) \\
{[0.000]}\end{array}$ \\
\hline State pre-election year & $\begin{array}{l}0.026 * * \\
(0.004) \\
{[0.000]}\end{array}$ & $\begin{array}{l}0.050 * * \\
(0.005) \\
{[0.000]}\end{array}$ & $\begin{array}{c}0.001 \\
(0.004) \\
{[1.000]}\end{array}$ & $\begin{array}{c}0.009 \\
(0.005) \\
{[0.234]}\end{array}$ & $\begin{array}{c}-0.020 * * \\
(0.004) \\
{[0.000]}\end{array}$ \\
\hline $\begin{array}{l}\text { No. observations } \\
\text { No. municipalities }\end{array}$ & $\begin{array}{c}16378 \\
604\end{array}$ & $\begin{array}{c}16400 \\
604\end{array}$ & $\begin{array}{c}16380 \\
604\end{array}$ & $\begin{array}{c}16382 \\
604\end{array}$ & $\begin{array}{c}15751 \\
597\end{array}$ \\
\hline
\end{tabular}

Notes: Dependent variables include the composite tax rate (first principal component), the three original tax multipliers and first differences in the composite tax rate. All models control for local population and an indicator for directly elected mayors. The four equations are jointly estimated in a seemingly unrelated regression (SUR) framework, controlling for municipality and year fixed effects. Standard errors clustered at the municipality level are presented in parentheses. Bonferroni-adjusted p-values (adjusted for multiple variable testing) are reported in square brackets. $+/^{*} / * *$ denote significance at the $10 / 5 / 1 \%$ level, adjusted for multiple variable testing. 
Table 12: Robustness: Baseline cycle with state economic controls (GMM w. year FE)

\begin{tabular}{|c|c|c|c|c|c|c|}
\hline \multirow{3}{*}{ Dependent variable } & (1) & (2) & (3) & \multirow{3}{*}{$\begin{array}{c}\text { (4) } \\
\text { Building } \\
\text { investment }\end{array}$} & \multirow{3}{*}{$\begin{array}{l}\text { (5) } \\
\text { Admin. } \\
\text { grants }\end{array}$} & \multirow{3}{*}{$\begin{array}{c}\text { (6) } \\
\text { Invest. } \\
\text { grants }\end{array}$} \\
\hline & Local & \multicolumn{2}{|c|}{ Current account } & & & \\
\hline & tax rates & Expend. & Revenues & & & \\
\hline Local post-election year & $\begin{array}{c}0.010+ \\
(0.005)\end{array}$ & $\begin{array}{c}-0.036 * * \\
(0.011)\end{array}$ & $\begin{array}{c}-0.009 \\
(0.012)\end{array}$ & $\begin{array}{c}-0.041 * * \\
(0.014)\end{array}$ & $\begin{array}{c}-0.005 \\
(0.010)\end{array}$ & $\begin{array}{c}0.028 \\
(0.019)\end{array}$ \\
\hline Local election year & $\begin{array}{c}-0.043 * * \\
(0.005)\end{array}$ & $\begin{array}{c}-0.021 * \\
(0.010)\end{array}$ & $\begin{array}{c}-0.029 * \\
(0.012)\end{array}$ & $\begin{array}{c}0.031+ \\
(0.016)\end{array}$ & $\begin{array}{c}-0.021 * \\
(0.009)\end{array}$ & $\begin{array}{l}0.088 * * \\
(0.019)\end{array}$ \\
\hline Local pre-election year & $\begin{array}{c}0.002 \\
(0.005)\end{array}$ & $\begin{array}{r}-0.012 \\
(0.010)\end{array}$ & $\begin{array}{c}-0.063 * * \\
(0.010)\end{array}$ & $\begin{array}{c}0.036 * \\
(0.014)\end{array}$ & $\begin{array}{c}-0.056 * * \\
(0.010)\end{array}$ & $\begin{array}{l}0.076 * * \\
(0.019)\end{array}$ \\
\hline State post-election year & $\begin{array}{c}-0.026 * * \\
(0.005)\end{array}$ & $\begin{array}{c}-0.013 \\
(0.010)\end{array}$ & $\begin{array}{c}-0.024 * \\
(0.011)\end{array}$ & $\begin{array}{c}0.034 * \\
(0.014)\end{array}$ & $\begin{array}{c}-0.014 \\
(0.010)\end{array}$ & $\begin{array}{c}0.001 \\
(0.017)\end{array}$ \\
\hline State election year & $\begin{array}{c}-0.040 * * \\
(0.005)\end{array}$ & $\begin{array}{l}0.030 * * \\
(0.010)\end{array}$ & $\begin{array}{c}-0.030 * * \\
(0.011)\end{array}$ & $\begin{array}{l}0.064 * * \\
(0.014)\end{array}$ & $\begin{array}{c}-0.022 * \\
(0.010)\end{array}$ & $\begin{array}{l}0.070 * * \\
(0.018)\end{array}$ \\
\hline State pre-election year & $\begin{array}{c}-0.021 * * \\
(0.004)\end{array}$ & $\begin{array}{l}0.036 * * \\
(0.010)\end{array}$ & $\begin{array}{c}0.021 * \\
(0.010)\end{array}$ & $\begin{array}{l}0.038 * * \\
(0.013)\end{array}$ & $\begin{array}{c}0.015 \\
(0.010)\end{array}$ & $\begin{array}{c}0.005 \\
(0.017)\end{array}$ \\
\hline Lagged dependent (t-1) & $\begin{array}{l}0.847 * * \\
(0.026)\end{array}$ & $\begin{array}{l}0.605 * * \\
(0.039)\end{array}$ & $\begin{array}{l}0.525 * * \\
(0.037)\end{array}$ & $\begin{array}{l}0.396 * * \\
(0.036)\end{array}$ & $\begin{array}{l}0.409 * * \\
(0.025)\end{array}$ & $\begin{array}{l}0.287 * * \\
(0.032)\end{array}$ \\
\hline Lagged dependent (t-2) & $\begin{array}{c}0.012 \\
(0.024)\end{array}$ & $\begin{array}{l}0.157 * * \\
(0.042)\end{array}$ & $\begin{array}{l}0.185 * * \\
(0.036)\end{array}$ & $\begin{array}{c}-0.075 * \\
(0.032)\end{array}$ & $\begin{array}{l}0.180 * * \\
(0.027)\end{array}$ & $\begin{array}{c}0.043 \\
(0.032)\end{array}$ \\
\hline Lagged dependent (t-3) & & $\begin{array}{c}0.011 \\
(0.029)\end{array}$ & $\begin{array}{c}0.013 \\
(0.026)\end{array}$ & $\begin{array}{c}0.059 * \\
(0.023)\end{array}$ & $\begin{array}{l}0.067 * * \\
(0.024)\end{array}$ & $\begin{array}{c}0.025 \\
(0.023)\end{array}$ \\
\hline $\begin{array}{l}\text { Lagged state unemployment } \\
\text { rate }\end{array}$ & $\begin{array}{c}0.004 \\
(0.003)\end{array}$ & $\begin{array}{r}-0.000 \\
(0.007)\end{array}$ & $\begin{array}{r}-0.005 \\
(0.007)\end{array}$ & $\begin{array}{c}-0.044 * * \\
(0.015)\end{array}$ & $\begin{array}{c}0.011 \\
(0.007)\end{array}$ & $\begin{array}{l}-0.061 * * \\
(0.016)\end{array}$ \\
\hline Lagged state GDP pc. & $\begin{array}{c}-0.023 * * \\
(0.004)\end{array}$ & $\begin{array}{c}-0.030 * * \\
(0.009)\end{array}$ & $\begin{array}{c}0.008 \\
(0.010)\end{array}$ & $\begin{array}{c}0.019 \\
(0.016)\end{array}$ & $\begin{array}{l}0.035 * * \\
(0.009)\end{array}$ & $\begin{array}{c}-0.032+ \\
(0.018)\end{array}$ \\
\hline $\begin{array}{l}\text { Lagged state GDP } \\
\text { growth rate }\end{array}$ & $\begin{array}{l}0.004+ \\
(0.002)\end{array}$ & $\begin{array}{c}0.001 \\
(0.005)\end{array}$ & $\begin{array}{c}0.013 * \\
(0.005)\end{array}$ & $\begin{array}{l}0.029 * * \\
(0.007)\end{array}$ & $\begin{array}{r}-0.005 \\
(0.005)\end{array}$ & $\begin{array}{c}0.019 * \\
(0.008)\end{array}$ \\
\hline No. observations & 14606 & 13531 & 13529 & 13372 & 13217 & 13142 \\
\hline $\mathrm{AR}(1) \mathrm{p}$-value & 0.000 & 0.000 & 0.000 & 0.000 & 0.000 & 0.000 \\
\hline $\mathrm{AR}(2) \mathrm{p}$-value & 0.318 & 0.437 & 0.113 & 0.406 & 0.872 & 0.606 \\
\hline Hansen Test p-value & 0.993 & 0.432 & 1.000 & 1.000 & 1.000 & 0.999 \\
\hline
\end{tabular}

Notes: The models rely on standardized dependent variables, originally measured in constant Euro per capita, except for the tax rate which is the standardized first principal component of three local tax multipliers. The six equations are estimated by the General Method of Moments, controlling for year fixed effects. The applied difference GMM estimation procedure relies on two-step estimation without fitting a constant. The variables population, directly elected mayor, lagged state unemployment rate, lagged state GDP and lagged state GDP growth rate are considered as predetermined. All models use lags 4-7 of the dependent variable as instruments (the equation on current expenditures uses lags 4-6). Standard errors clustered at the municipality level are presented in parentheses. $+,{ }^{*},{ }^{*} *$ denote significance at the $10 / 5 / 1 \%$. 


\section{A Appendix}

Table A1: Current election day regulations

\begin{tabular}{|c|c|}
\hline Schleswig-Holstein & $\begin{array}{l}\text { Local elections take place every } 5 \text { years, on a Sunday in May. } \\
\text { State elections take place every } 5 \text { years, the date has to lie between } 58 \text { and } \\
60 \text { months after the beginning of the electoral term. }\end{array}$ \\
\hline Lower Saxony & $\begin{array}{l}\text { Local elections take place every } 5 \text { years, on a Sunday, before the end of the } \\
\text { previous election period. } \\
\text { State elections take place every } 5 \text { years, the date has to lie between } 56 \text { and } \\
59 \text { months after the beginning of the electoral term. }\end{array}$ \\
\hline Nord Rhine-Westphalia & $\begin{array}{l}\text { Local elections take place every } 5 \text { years, on a Sunday, on a day determined } \\
\text { by the oversight authority. } \\
\text { State elections take place every } 5 \text { years, in the last quarter before the end of } \\
\text { the electoral term. }\end{array}$ \\
\hline Hesse & $\begin{array}{l}\text { Local elections take place every } 5 \text { years, on a Sunday in March. } \\
\text { State elections take place every } 5 \text { years, the date has to lie before the end of } \\
\text { the electoral term. }\end{array}$ \\
\hline Rhineland-Palatinate & $\begin{array}{l}\text { Local elections take place every } 5 \text { years, between April } 1 \text { and June } 30 \text {. } \\
\text { State elections take place every } 5 \text { years, the date has to lie between } 56 \text { and } \\
59 \text { months after the beginning of the electoral term. }\end{array}$ \\
\hline Baden-Württemberg & $\begin{array}{l}\text { Local elections take place every } 5 \text { years, on a Sunday between May } 10 \text { and } \\
\text { November } 20 \text {. } \\
\text { State elections take place every } 5 \text { years, the date has to lie before the end of } \\
\text { the electoral term. }\end{array}$ \\
\hline Bavaria & $\begin{array}{l}\text { Local elections take place every } 6 \text { years, on a Sunday in March. } \\
\text { State elections take place every } 5 \text { years, the date has to lie between } 59 \text { and } \\
62 \text { months after the last state elections. }\end{array}$ \\
\hline Saarland & $\begin{array}{l}\text { Local elections take place every } 5 \text { years, at a date determined by the state } \\
\text { government. } \\
\text { State elections take place every } 5 \text { years, the date has to lie between } 57 \text { and } \\
60 \text { months after the beginning of the electoral term. }\end{array}$ \\
\hline
\end{tabular}

Source: Various current state election laws (as by August 2014). 
Table A2: Election dates in West Germany 1974-2008

\begin{tabular}{|c|c|c|c|c|c|c|c|c|c|c|c|c|c|c|c|c|c|}
\hline & \multicolumn{3}{|c|}{ BW } & \multicolumn{2}{|c|}{ BY } & \multicolumn{2}{|c|}{$\mathrm{HE}$} & \multicolumn{2}{|c|}{ LS } & \multicolumn{2}{|c|}{ NRW } & \multicolumn{2}{|c|}{$\mathrm{RP}$} & \multicolumn{2}{|c|}{ SA } & \multicolumn{2}{|c|}{ SH } \\
\hline & Year & Local & State & Local & State & Local & State & Local & State & Local & State & Local & State & Local & State & Local & State \\
\hline & 1974 & & & & $10-27$ & & $10-27$ & & 06-09 & & & $03-17$ & & 05-05 & & $03-24$ & \\
\hline & 1975 & 04-20 & & & & & & & & 05-04 & 05-04 & & 03-09 & & 05-04 & & 04-13 \\
\hline & 1976 & & 04-04 & & & & & $10-03$ & $*$ & & & & & & & & \\
\hline & 1977 & & & & & $03-20$ & & & & & & & & & & & \\
\hline & 1978 & & & 03-05 & $10-15$ & & $10-08$ & & 06-04* & & & & & & & $04-26$ & \\
\hline & 1979 & & & & & & & & & 09-30 & & 06-10 & 03-18 & $06-10$ & & & 04-29 \\
\hline & 1980 & $06-22$ & 03-16 & & & & & & & & 05-11 & & & & $04-27$ & & \\
\hline & 1981 & & & & & $03-22$ & & $09-27$ & & & & & & & & & \\
\hline & 1982 & & & & $10-10$ & & 09-26* & & 03-21 & & & & & & & 03-07 & \\
\hline & 1983 & & & & & & $09-25^{*}$ & & & & & & 03-06 & & & & 03-13 \\
\hline & 1984 & $10-28$ & 03-25 & 03-18 & & & & & & 09-30 & & $06-17$ & & $06-17$ & & & \\
\hline & 1985 & & & & & $03-10$ & & & & & 05-12 & & & & $05-10$ & & \\
\hline & 1986 & & & & $10-12$ & & & $10-05$ & $06-15$ & & & & & & & 03-02 & \\
\hline & 1987 & & & & & & 04-05 & & & & & & $05-17$ & & & & 09-13* \\
\hline & 1988 & & 03-20 & & & & & & & & & & & & & & 05-08* \\
\hline & 1989 & $10-22$ & & & & 03-12 & & & & $10-01$ & & 06-18 & & $06-18$ & & & \\
\hline er & 1990 & & & 03-18 & $10-14$ & & & & $05-13$ & & 05-13 & & & & $01-28$ & $03-25$ & \\
\hline & 1991 & & & & & & $01-20$ & $10-06$ & & & & & 04-21 & & & & \\
\hline & 1992 & & 04-05 & & & & & & & & & & & & & & 04-05 \\
\hline & 1993 & & & & & 03-07 & & & & & & & & & & & \\
\hline & 1994 & 06-12 & & & $09-25$ & & & & 03-13 & $10-16$ & & 06-12 & & 06-12 & $10-16$ & $03-20$ & \\
\hline & 1995 & & & & & & 02-19 & & & & $05-14$ & & & & & & \\
\hline & 1996 & & 03-24 & 03-10 & & & & 09-15 & & & & & 03-24 & & & & 03-24 \\
\hline & 1997 & & & & & $03-20$ & & & & & & & & & & & \\
\hline & 1998 & & & & 09-13 & & & & 03-01 & & & & & & & $03-22$ & \\
\hline & 1999 & $10-24$ & & & & & $02-07$ & & & 09-12 & & $06-13$ & & 06-13 & 09-05 & & \\
\hline & 2000 & & & & & & & & & & $05-14$ & & & & & & $02-27$ \\
\hline & 2001 & & $03-25$ & & & 03-18 & & 09-09 & & & & & $03-25$ & & & & \\
\hline & 2002 & & & 03-03 & & & & & & & & & & & & & \\
\hline & 2003 & & & & $09-21$ & & 02-02 & & 02-02 & & & & & & & 03-02 & \\
\hline & 2004 & $06-13$ & & & & & & & & 09-24 & & 06-13 & & 06-13 & 09-05 & & \\
\hline & 2005 & & & & & & & & & & $05-22$ & & & & & & $02-20$ \\
\hline & 2006 & & 03-26 & & & $03-26$ & & $09-10$ & & & & & $03-27$ & & & & \\
\hline & 2007 & & & & & & & & & & & & & & & & \\
\hline & 2008 & & & 03-02 & $09-21$ & & $01-27$ & & $01-27$ & & & & & & & $05-25$ & \\
\hline
\end{tabular}


Table A3: Robustness: Partisanship alignment with alternative election year indicators (SUR w. mun./year FE)

\begin{tabular}{|c|c|c|c|c|c|c|}
\hline \multirow{3}{*}{ Dependent variable } & & $(2)$ & $(3)$ & \multirow{3}{*}{$\begin{array}{c}\text { (4) } \\
\text { Building } \\
\text { investment }\end{array}$} & \multirow{3}{*}{$\begin{array}{c}\text { (5) } \\
\text { Admin. } \\
\text { grants }\end{array}$} & \multirow{3}{*}{$\begin{array}{c}\text { (6) } \\
\text { Invest. } \\
\text { grants }\end{array}$} \\
\hline & Local & \multicolumn{2}{|c|}{ Current account } & & & \\
\hline & tax rates & Expend. & Revenues & & & \\
\hline Local post-election year (alt.) & $\begin{array}{c}-0.064 * * \\
(0.011) \\
{[0.000]}\end{array}$ & $\begin{array}{c}-0.057 * * \\
(0.015) \\
{[0.001]}\end{array}$ & $\begin{array}{c}-0.055 * \\
(0.018) \\
{[0.011]}\end{array}$ & $\begin{array}{r}-0.019 \\
(0.026) \\
{[1.000]}\end{array}$ & $\begin{array}{c}-0.015 \\
(0.016) \\
{[1.000]}\end{array}$ & $\begin{array}{l}0.122 * * \\
(0.030) \\
{[0.000]}\end{array}$ \\
\hline Local pre-election year (alt.) & $\begin{array}{l}0.057 * * \\
(0.012) \\
{[0.000]}\end{array}$ & $\begin{array}{c}0.005 \\
(0.017) \\
{[1.000]}\end{array}$ & $\begin{array}{c}-0.055 * \\
(0.021) \\
{[0.047]}\end{array}$ & $\begin{array}{c}0.035 \\
(0.032) \\
{[1.000]}\end{array}$ & $\begin{array}{c}-0.050 * \\
(0.018) \\
{[0.039]}\end{array}$ & $\begin{array}{c}0.061 \\
(0.033) \\
{[0.380]}\end{array}$ \\
\hline State post-election year (alt.) & $\begin{array}{c}-0.006 \\
(0.011) \\
{[1.000]}\end{array}$ & $\begin{array}{c}0.044 * \\
(0.014) \\
{[0.013]}\end{array}$ & $\begin{array}{c}0.001 \\
(0.017) \\
{[1.000]}\end{array}$ & $\begin{array}{c}0.036 \\
(0.026) \\
{[0.987]}\end{array}$ & $\begin{array}{c}-0.062 * * \\
(0.016) \\
{[0.001]}\end{array}$ & $\begin{array}{c}0.077 * \\
(0.026) \\
{[0.016]}\end{array}$ \\
\hline State pre-election year (alt.) & $\begin{array}{c}-0.037 * * \\
(0.011) \\
{[0.007]}\end{array}$ & $\begin{array}{c}0.029 \\
(0.016) \\
{[0.422]}\end{array}$ & $\begin{array}{c}0.016 \\
(0.015) \\
{[1.000]}\end{array}$ & $\begin{array}{c}-0.010 \\
(0.025) \\
{[1.000]}\end{array}$ & $\begin{array}{c}-0.008 \\
(0.014) \\
{[1.000]}\end{array}$ & $\begin{array}{c}0.008 \\
(0.028) \\
{[1.000]}\end{array}$ \\
\hline $\begin{array}{l}\text { Partisan alignment } \times \\
\text { local post-election year (alt.) }\end{array}$ & $\begin{array}{c}-0.069 * * \\
(0.014) \\
{[0.000]}\end{array}$ & $\begin{array}{c}-0.005 \\
(0.020) \\
{[1.000]}\end{array}$ & $\begin{array}{c}0.019 \\
(0.021) \\
{[1.000]}\end{array}$ & $\begin{array}{c}0.025 \\
(0.035) \\
{[1.000]}\end{array}$ & $\begin{array}{c}0.025 \\
(0.022) \\
{[1.000]}\end{array}$ & $\begin{array}{r}-0.087 \\
(0.044) \\
{[0.273]}\end{array}$ \\
\hline $\begin{array}{l}\text { Partisan alignment } \times \\
\text { local pre-election year (alt.) }\end{array}$ & $\begin{array}{c}-0.133 * * \\
(0.015) \\
{[0.000]}\end{array}$ & $\begin{array}{c}0.002 \\
(0.020) \\
{[1.000]}\end{array}$ & $\begin{array}{c}0.016 \\
(0.023) \\
{[1.000]}\end{array}$ & $\begin{array}{c}0.106+ \\
(0.040) \\
{[0.053]}\end{array}$ & $\begin{array}{c}0.042 \\
(0.024) \\
{[0.471]}\end{array}$ & $\begin{array}{c}0.039 \\
(0.039) \\
{[1.000]}\end{array}$ \\
\hline $\begin{array}{l}\text { Partisan alignment } \times \\
\text { state post-election year (alt.) }\end{array}$ & $\begin{array}{c}0.019 \\
(0.015) \\
{[1.000]}\end{array}$ & $\begin{array}{c}0.006 \\
(0.018) \\
{[1.000]}\end{array}$ & $\begin{array}{r}-0.020 \\
(0.020) \\
{[1.000]}\end{array}$ & $\begin{array}{c}0.036 \\
(0.033) \\
{[1.000]}\end{array}$ & $\begin{array}{l}0.067 * * \\
(0.020) \\
{[0.005]}\end{array}$ & $\begin{array}{c}-0.001 \\
(0.034) \\
{[1.000]}\end{array}$ \\
\hline $\begin{array}{l}\text { Partisan alignment } \times \\
\text { state pre-election year (alt.) }\end{array}$ & $\begin{array}{r}-0.004 \\
(0.014) \\
{[1.000]}\end{array}$ & $\begin{array}{c}0.018 \\
(0.020) \\
{[1.000]}\end{array}$ & $\begin{array}{c}0.002 \\
(0.021) \\
{[1.000]}\end{array}$ & $\begin{array}{c}0.049 \\
(0.035) \\
{[0.919]}\end{array}$ & $\begin{array}{c}0.043 \\
(0.021) \\
{[0.255]}\end{array}$ & $\begin{array}{c}0.048 \\
(0.037) \\
{[1.000]}\end{array}$ \\
\hline $\begin{array}{l}\text { Partisan alignment } \\
\text { state-local gov. }\end{array}$ & $\begin{array}{c}0.013 \\
(0.022) \\
{[1.000]}\end{array}$ & $\begin{array}{r}-0.039 \\
(0.020) \\
{[0.323]}\end{array}$ & $\begin{array}{r}-0.019 \\
(0.020) \\
{[1.000]}\end{array}$ & $\begin{array}{c}-0.077+ \\
(0.030) \\
{[0.063]}\end{array}$ & $\begin{array}{c}-0.075 * * \\
(0.022) \\
{[0.005]}\end{array}$ & $\begin{array}{c}0.026 \\
(0.030) \\
{[1.000]}\end{array}$ \\
\hline No. observations & 15046 & 14806 & 14816 & 14758 & 14628 & 14746 \\
\hline No. municipalities & 580 & 578 & 577 & 580 & 580 & 579 \\
\hline
\end{tabular}

Notes: The models rely on standardized dependent variables, originally measured in constant Euro per capita, except for the tax rate which is the standardized first principal component of three local tax multipliers. All models control for local population and an indicator for directly elected mayors. The alternative pre-election/postelection year indicators measure the share of the current year that coincided with the 12 months before/after local or state elections. The partisanship alignment variable takes 1 if in the previous year the party with the most seats in the local council was also part of the state government. The six equations are jointly estimated in a seemingly unrelated regression (SUR) framework, controlling for municipality and year fixed effects. Standard errors clustered at the municipality level are presented in parentheses. Bonferroni-adjusted p-values (adjusted for multiple variable testing) are reported in square brackets. $+/^{*} /{ }^{* *}$ denote significance at the $10 / 5 / 1 \%$ level, adjusted for multiple variable testing. 
Table A4: Electoral competition and cycles with alternative election years indicators (SUR w. mun./year FE)

\begin{tabular}{|c|c|c|c|c|c|c|}
\hline \multirow{3}{*}{ Dependent variable } & & $(2)$ & (3) & \multirow{3}{*}{$\begin{array}{c}(4) \\
\text { Building } \\
\text { investment }\end{array}$} & \multirow{3}{*}{$\begin{array}{l}\text { (5) } \\
\text { Admin. } \\
\text { grants }\end{array}$} & \multirow{3}{*}{$\begin{array}{c}(6) \\
\text { Invest. } \\
\text { grants }\end{array}$} \\
\hline & Local & \multicolumn{2}{|c|}{ Current account } & & & \\
\hline & tax rates & Expend. & Revenues & & & \\
\hline Local post-election year (alt.) & $\begin{array}{c}-0.085 * * \\
(0.013) \\
{[0.000]}\end{array}$ & $\begin{array}{c}-0.085 * * \\
(0.017) \\
{[0.000]}\end{array}$ & $\begin{array}{c}-0.036 \\
(0.019) \\
{[0.403]}\end{array}$ & $\begin{array}{c}-0.001 \\
(0.030) \\
{[1.000]}\end{array}$ & $\begin{array}{c}0.013 \\
(0.017) \\
{[1.000]}\end{array}$ & $\begin{array}{c}0.042 \\
(0.033) \\
{[1.000]}\end{array}$ \\
\hline Local pre-election year (alt.) & $\begin{array}{c}-0.024 \\
(0.012) \\
{[0.294]}\end{array}$ & $\begin{array}{c}0.010 \\
(0.017) \\
{[1.000]}\end{array}$ & $\begin{array}{c}-0.093 * * \\
(0.021) \\
{[0.000]}\end{array}$ & $\begin{array}{l}0.132 * * \\
(0.031) \\
{[0.000]}\end{array}$ & $\begin{array}{c}-0.061 * * \\
(0.019) \\
{[0.007]}\end{array}$ & $\begin{array}{c}0.106 * \\
(0.038) \\
{[0.031]}\end{array}$ \\
\hline State post-election year (alt.) & $\begin{array}{c}-0.025 \\
(0.013) \\
{[0.340]}\end{array}$ & $\begin{array}{c}0.044 * \\
(0.017) \\
{[0.050]}\end{array}$ & $\begin{array}{c}-0.003 \\
(0.017) \\
{[1.000]}\end{array}$ & $\begin{array}{c}0.068 \\
(0.029) \\
{[0.108]}\end{array}$ & $\begin{array}{r}-0.017 \\
(0.018) \\
{[1.000]}\end{array}$ & $\begin{array}{c}0.069 \\
(0.029) \\
{[0.105]}\end{array}$ \\
\hline State pre-election year (alt.) & $\begin{array}{c}-0.020 \\
(0.010) \\
{[0.227]}\end{array}$ & $\begin{array}{l}0.053 * * \\
(0.015) \\
{[0.003]}\end{array}$ & $\begin{array}{c}0.026 \\
(0.017) \\
{[0.782]}\end{array}$ & $\begin{array}{c}-0.029 \\
(0.026) \\
{[1.000]}\end{array}$ & $\begin{array}{c}-0.001 \\
(0.016) \\
{[1.000]}\end{array}$ & $\begin{array}{c}0.034 \\
(0.030) \\
{[1.000]}\end{array}$ \\
\hline $\begin{array}{l}\text { MOV in state elections } \times \\
\text { local post-election year (alt.) }\end{array}$ & $\begin{array}{c}0.109 \\
(0.076) \\
{[0.897]}\end{array}$ & $\begin{array}{l}0.340 * * \\
(0.093) \\
{[0.001]}\end{array}$ & $\begin{array}{c}0.074 \\
(0.098) \\
{[1.000]}\end{array}$ & $\begin{array}{c}0.081 \\
(0.171) \\
{[1.000]}\end{array}$ & $\begin{array}{c}-0.064 \\
(0.091) \\
{[1.000]}\end{array}$ & $\begin{array}{c}0.266 \\
(0.224) \\
{[1.000]}\end{array}$ \\
\hline $\begin{array}{l}\text { MOV in state elections } \times \\
\text { local pre-election year (alt.) }\end{array}$ & $\begin{array}{c}0.095 \\
(0.058) \\
{[0.626]}\end{array}$ & $\begin{array}{c}0.032 \\
(0.075) \\
{[1.000]}\end{array}$ & $\begin{array}{l}0.326 * * \\
(0.092) \\
{[0.002]}\end{array}$ & $\begin{array}{c}-0.108 \\
(0.149) \\
{[1.000]}\end{array}$ & $\begin{array}{c}0.193 \\
(0.090) \\
{[0.186]}\end{array}$ & $\begin{array}{c}0.135 \\
(0.215) \\
{[1.000]}\end{array}$ \\
\hline $\begin{array}{l}\text { MOV in state elections } \times \\
\text { state post-election year (alt.) }\end{array}$ & $\begin{array}{c}0.025 \\
(0.079) \\
{[1.000]}\end{array}$ & $\begin{array}{c}-0.031 \\
(0.092) \\
{[1.000]}\end{array}$ & $\begin{array}{c}-0.154 \\
(0.082) \\
{[0.358]}\end{array}$ & $\begin{array}{c}0.017 \\
(0.158) \\
{[1.000]}\end{array}$ & $\begin{array}{r}-0.056 \\
(0.099) \\
{[1.000]}\end{array}$ & $\begin{array}{c}0.301 \\
(0.167) \\
{[0.424]}\end{array}$ \\
\hline $\begin{array}{l}\text { MOV in state elections } \times \\
\text { state pre-election year (alt.) }\end{array}$ & $\begin{array}{c}0.002 \\
(0.054) \\
{[1.000]}\end{array}$ & $\begin{array}{c}-0.054 \\
(0.078) \\
{[1.000]}\end{array}$ & $\begin{array}{c}-0.016 \\
(0.103) \\
{[1.000]}\end{array}$ & $\begin{array}{c}0.181 \\
(0.151) \\
{[1.000]}\end{array}$ & $\begin{array}{c}0.118 \\
(0.085) \\
{[0.993]}\end{array}$ & $\begin{array}{r}-0.151 \\
(0.168) \\
{[1.000]}\end{array}$ \\
\hline $\begin{array}{l}\text { Margin of victory in past } \\
\text { state elections }\end{array}$ & $\begin{array}{r}-0.158 \\
(0.121) \\
{[1.000]}\end{array}$ & $\begin{array}{c}-0.009 \\
(0.115) \\
{[1.000]}\end{array}$ & $\begin{array}{c}0.179 \\
(0.110) \\
{[0.625]}\end{array}$ & $\begin{array}{c}0.137 \\
(0.161) \\
{[1.000]}\end{array}$ & $\begin{array}{c}0.203 \\
(0.129) \\
{[0.696]}\end{array}$ & $\begin{array}{c}0.509 * \\
(0.171) \\
{[0.017]}\end{array}$ \\
\hline $\begin{array}{l}\text { No. observations } \\
\text { No. municipalities }\end{array}$ & $\begin{array}{c}13260 \\
548\end{array}$ & $\begin{array}{c}13268 \\
547\end{array}$ & $\begin{array}{c}13227 \\
549\end{array}$ & $\begin{array}{c}13472 \\
551\end{array}$ & $\begin{array}{c}13165 \\
551\end{array}$ & $\begin{array}{c}13198 \\
548\end{array}$ \\
\hline $\begin{array}{l}\text { Notes: The models rely on stan } \\
\text { except for the tax rate which is } \\
\text { models control for local populatic } \\
\text { election year indicators measure } \\
\text { or state elections. The margin of } \\
\text { vote shares for the two largest } \\
\text { seemingly unrelated regression } \\
\text { errors clustered at the municipa } \\
\text { for multiple variable testing) are } \\
\text { adjusted for multiple variable te }\end{array}$ & $\begin{array}{l}\text { ed depeno } \\
\text { andardize } \\
\text { an indicat } \\
\text { re of the } \\
\text { y (MOV) } \\
\text { in the la } \\
\text { framewor } \\
\text { vel are pr } \\
\text { ted in squ }\end{array}$ & $\begin{array}{l}\text { for directl } \\
\text { rent year } \\
\text { past state } \\
\text { state elect } \\
\text { controlling } \\
\text { nted in p } \\
\text { brackets }\end{array}$ & $\begin{array}{l}\text { elected m } \\
\text { at coincid } \\
\text { lections } \mathrm{n} \\
\text { ns. The } \\
\text { for munic } \\
\text { entheses. } \\
+/^{*} /{ }^{*} \mathrm{~d}\end{array}$ & $\begin{array}{l}\text { rs. The alt } \\
\text { with the } 12 \\
\text { sures the d } \\
\text { equations } \\
\text { lity and ye } \\
\text { onferroni-ac }\end{array}$ & $\begin{array}{l}\text { ative pre- } \\
\text { onths bef } \\
\text { cence bet } \\
\text { jointly } \\
\text { fixed effe } \\
\text { ted p-va } \\
\text { at the }\end{array}$ & $\begin{array}{l}\text { per cap } \\
\text { ipliers. } \\
\text { ction/p } \\
\text { /after l } \\
\text { en the l } \\
\text { mated } \\
\text { Stand } \\
\text { s (adju } \\
5 / 1 \% \text { le }\end{array}$ \\
\hline
\end{tabular}


Table A5: Robustness: Partisanship alignment and cycles with state controls (SUR w. mun./year FE)

\begin{tabular}{|c|c|c|c|c|c|c|}
\hline \multirow{3}{*}{ Dependent variable } & \multirow{3}{*}{$\begin{array}{c}(1) \\
\text { Local } \\
\text { tax rates }\end{array}$} & $(2)$ & (3) & \multirow{3}{*}{$\begin{array}{c}(4) \\
\text { Building } \\
\text { investment }\end{array}$} & \multirow{3}{*}{$\begin{array}{c}(5) \\
\text { Admin. } \\
\text { grants }\end{array}$} & \multirow{3}{*}{$\begin{array}{c}\quad(6) \\
\text { Invest. } \\
\text { grants }\end{array}$} \\
\hline & & \multicolumn{2}{|c|}{ Current account } & & & \\
\hline & & Expend. & Revenues & & & \\
\hline \multirow[t]{2}{*}{ Local post-election year } & 0.010 & $-0.042 * *$ & $-0.065 * *$ & -0.002 & -0.029 & $0.105 * *$ \\
\hline & $(0.009)$ & $\begin{array}{l}(0.013) \\
{[0.010]}\end{array}$ & $\begin{array}{l}(0.015) \\
{[0.000]}\end{array}$ & $\begin{array}{l}(0.021) \\
{[1.000]}\end{array}$ & $\begin{array}{l}(0.013) \\
{[0.173]}\end{array}$ & $\begin{array}{l}(0.024) \\
{[0.000]}\end{array}$ \\
\hline \multirow{3}{*}{ Local election year } & 0.010 & $-0.040 *$ & $-0.079 * *$ & 0.015 & $-0.041 *$ & $0.088 * *$ \\
\hline & $(0.010)$ & $(0.014)$ & $(0.015)$ & $(0.026)$ & $(0.014)$ & $(0.026)$ \\
\hline & {$[1.000]$} & {$[0.035]$} & {$[0.000]$} & {$[1.000]$} & {$[0.026]$} & {$[0.005]$} \\
\hline \multirow[t]{3}{*}{ Local pre-election year } & $0.092 * *$ & 0.019 & $-0.039 *$ & 0.007 & $-0.053 * *$ & 0.057 \\
\hline & $(0.009)$ & $(0.012)$ & $(0.014)$ & $(0.022)$ & $(0.013)$ & $(0.025)$ \\
\hline & {$[0.000]$} & {$[0.640]$} & {$[0.031]$} & {$[1.000]$} & {$[0.000]$} & {$[0.117]$} \\
\hline \multirow{3}{*}{ State post-election year } & $-0.024 *$ & -0.004 & -0.015 & 0.036 & -0.026 & -0.007 \\
\hline & $(0.008)$ & $(0.011)$ & $(0.014)$ & $(0.022)$ & $(0.014)$ & $(0.024)$ \\
\hline & {$[0.018]$} & {$[1.000]$} & {$[1.000]$} & {$[0.610]$} & {$[0.386]$} & {$[1.000]$} \\
\hline \multirow[t]{3}{*}{ State election year } & $-0.036 * *$ & $0.048 * *$ & 0.020 & 0.018 & $-0.048 *$ & $0.064+$ \\
\hline & $(0.010)$ & $(0.014)$ & $(0.016)$ & $(0.026)$ & $(0.015)$ & $(0.025)$ \\
\hline & {$[0.004]$} & {$[0.004]$} & {$[1.000]$} & {$[1.000]$} & {$[0.011]$} & {$[0.075]$} \\
\hline \multirow[t]{3}{*}{ State pre-election year } & $-0.034 * *$ & 0.027 & $0.036 *$ & -0.002 & 0.009 & -0.033 \\
\hline & $(0.009)$ & $(0.014)$ & $(0.013)$ & $(0.021)$ & $(0.014)$ & $(0.025)$ \\
\hline & {$[0.001]$} & {$[0.304]$} & {$[0.034]$} & {$[1.000]$} & {$[1.000]$} & {$[1.000]$} \\
\hline \multirow{3}{*}{$\begin{array}{l}\text { Partisan alignment } \times \\
\text { local post-election year }\end{array}$} & $-0.071 * *$ & -0.003 & 0.033 & -0.021 & 0.026 & $-0.096 *$ \\
\hline & $(0.012)$ & $(0.016)$ & $(0.018)$ & $(0.028)$ & $(0.017)$ & $(0.033)$ \\
\hline & {$[0.000]$} & [1.000] & {$[0.375]$} & [1.000] & {$[0.755]$} & {$[0.024]$} \\
\hline \multirow{3}{*}{$\begin{array}{l}\text { Partisan alignment } \times \\
\text { local election year }\end{array}$} & $-0.110 * *$ & 0.031 & 0.037 & 0.066 & 0.043 & -0.002 \\
\hline & $(0.013)$ & $(0.018)$ & $(0.018)$ & $(0.034)$ & $(0.019)$ & $(0.035)$ \\
\hline & {$[0.000]$} & {$[0.439]$} & {$[0.256]$} & {$[0.330]$} & {$[0.159]$} & {$[1.000]$} \\
\hline \multirow{3}{*}{$\begin{array}{l}\text { Partisan alignment } \times \\
\text { local pre-election year }\end{array}$} & $-0.087 * *$ & -0.011 & 0.003 & $0.090 * *$ & 0.037 & 0.004 \\
\hline & $(0.010)$ & $(0.014)$ & $(0.016)$ & $(0.026)$ & $(0.017)$ & $(0.030)$ \\
\hline & {$[0.000]$} & {$[1.000]$} & {$[1.000]$} & {$[0.004]$} & {$[0.183]$} & {$[1.000]$} \\
\hline \multirow{3}{*}{$\begin{array}{l}\text { Partisan alignment } \times \\
\text { state post-election year }\end{array}$} & 0.008 & 0.012 & 0.000 & 0.017 & 0.019 & 0.026 \\
\hline & $(0.010)$ & $(0.013)$ & $(0.016)$ & $(0.025)$ & $(0.017)$ & $(0.029)$ \\
\hline & [1.000] & {$[1.000]$} & [1.000] & [1.000] & {$[1.000]$} & {$[1.000]$} \\
\hline \multirow{3}{*}{$\begin{array}{l}\text { Partisan alignment } \times \\
\text { state election year }\end{array}$} & 0.020 & 0.004 & -0.026 & $0.078+$ & $0.069 * *$ & 0.019 \\
\hline & $(0.014)$ & $(0.018)$ & $(0.019)$ & $(0.031)$ & $(0.020)$ & $(0.033)$ \\
\hline & {$[0.893]$} & {$[1.000]$} & [1.000] & {$[0.074]$} & {$[0.002]$} & {$[1.000]$} \\
\hline \multirow{3}{*}{$\begin{array}{l}\text { Partisan alignment } \times \\
\text { state pre-election year }\end{array}$} & $0.035 *$ & -0.001 & -0.004 & 0.048 & 0.029 & 0.056 \\
\hline & $(0.012)$ & $(0.018)$ & $(0.018)$ & $(0.028)$ & $(0.019)$ & $(0.034)$ \\
\hline & {$[0.022]$} & {$[1.000]$} & {$[1.000]$} & {$[0.546]$} & {$[0.826]$} & {$[0.573]$} \\
\hline \multirow{3}{*}{$\begin{array}{l}\text { Partisan alignment } \\
\text { state-local gov. }\end{array}$} & -0.001 & -0.046 & -0.029 & -0.071 & $-0.089 * *$ & 0.041 \\
\hline & $(0.019)$ & $(0.021)$ & $(0.021)$ & $(0.033)$ & $(0.023)$ & $(0.033)$ \\
\hline & {$[1.000]$} & {$[0.177]$} & {$[1.000]$} & {$[0.175]$} & {$[0.001]$} & {$[1.000]$} \\
\hline \multirow{3}{*}{$\begin{array}{l}\text { Lagged state unemployment } \\
\text { rate }\end{array}$} & $0.252 * *$ & $0.071 * *$ & $0.035 * *$ & $-0.121 * *$ & 0.010 & $-0.101 * *$ \\
\hline & $(0.010)$ & $(0.009)$ & $(0.009)$ & $(0.015)$ & $(0.010)$ & $(0.016)$ \\
\hline & {$[0.000]$} & {$[0.000]$} & {$[0.000]$} & {$[0.000]$} & {$[1.000]$} & [0.000] \\
\hline Lagged state GDP pc. & $-0.078 * *$ & $-0.027 *$ & $0.036 * *$ & $-0.035 *$ & $0.054 * *$ & $-0.040 *$ \\
\hline & $(0.012)$ & (0.009) & $(0.009)$ & $(0.013)$ & $(0.010)$ & $(0.013)$ \\
\hline & {$[0.000]$} & {$[0.011]$} & {$[0.000]$} & {$[0.030]$} & {$[0.000]$} & {$[0.014]$} \\
\hline Lagged state GDP growth rate & $0.029 * *$ & 0.013 & $0.026 * *$ & $0.045 * *$ & 0.011 & $0.032 * *$ \\
\hline & $(0.004)$ & $(0.006)$ & $(0.007)$ & $(0.008)$ & $(0.006)$ & $(0.008)$ \\
\hline & {$[0.000]$} & {$[0.116]$} & {$[0.001]$} & {$[0.000]$} & {$[0.366]$} & {$[0.001]$} \\
\hline & 150 & 1 & 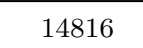 & & 28 & 14746 \\
\hline No. municipalities & 580 & 578 & 577 & 580 & 580 & 579 \\
\hline
\end{tabular}

Notes: The models rely on standardized dependent variables, originally measured in constant Euro per capita, except for the tax rate which is the standardized first principal component of three local tax multipliers. All models control for local population and an indicator for directly elected mayors. The six equations are jointly estimated in a seemingly unrelated regression (SUR) framework, controlling for municipality and year fixed effects. Standard errors clustered at the municipality level are presented in parentheses. Bonferroni-adjusted p-values (adjusted for multiple variable testing) are reported in square brackets. $+/^{*} / * *$ denote significance at the $10 / 5 / 1 \%$ level, adjusted for multiple variable testing. 
Table A6: Robustness: Electoral competition and cycles w. state controls (SUR w. mun./year FE)

\begin{tabular}{|c|c|c|c|c|c|c|}
\hline \multirow{3}{*}{ Dependent variable } & \multirow{3}{*}{$\begin{array}{c}(1) \\
\text { Local } \\
\text { tax rates }\end{array}$} & $(2)$ & (3) & \multirow{3}{*}{$\begin{array}{c}\text { (4) } \\
\text { Building } \\
\text { investment }\end{array}$} & \multirow{3}{*}{$\begin{array}{c}(5) \\
\text { Admin. } \\
\text { grants }\end{array}$} & \multirow{3}{*}{$\begin{array}{c}\quad(6) \\
\text { Invest. } \\
\text { grants }\end{array}$} \\
\hline & & \multicolumn{2}{|c|}{ Current account } & & & \\
\hline & & Expend. & Revenues & & & \\
\hline \multirow[t]{3}{*}{ Local post-election year } & $-0.031 *$ & $-0.088 * *$ & $-0.057 * *$ & -0.016 & -0.013 & 0.035 \\
\hline & $(0.010)$ & $(0.014)$ & $(0.016)$ & $(0.024)$ & $(0.015)$ & $(0.029)$ \\
\hline & {$[0.017]$} & {$[0.000]$} & {$[0.001]$} & [1.000] & {$[1.000]$} & {$[1.000]$} \\
\hline \multirow[t]{3}{*}{ Local election year } & $-0.060 * *$ & -0.032 & $-0.075 * *$ & $0.072 *$ & -0.022 & 0.061 \\
\hline & $(0.010)$ & $(0.014)$ & $(0.016)$ & $(0.026)$ & $(0.014)$ & $(0.029)$ \\
\hline & {$[0.000]$} & {$[0.129]$} & {$[0.000]$} & {$[0.030]$} & {$[0.790]$} & {$[0.213]$} \\
\hline \multirow[t]{3}{*}{ Local pre-election year } & $0.040 * *$ & -0.001 & $-0.054 * *$ & $0.077 * *$ & $-0.062 * *$ & $0.094 *$ \\
\hline & $(0.011)$ & $(0.014)$ & $(0.016)$ & $(0.023)$ & $(0.016)$ & $(0.030)$ \\
\hline & {$[0.001]$} & {$[1.000]$} & {$[0.007]$} & {$[0.005]$} & {$[0.000]$} & {$[0.012]$} \\
\hline \multirow[t]{3}{*}{ State post-election year } & $-0.038 * *$ & 0.027 & -0.017 & $0.056+$ & 0.005 & -0.026 \\
\hline & $(0.010)$ & $(0.013)$ & $(0.015)$ & $(0.023)$ & $(0.015)$ & $(0.024)$ \\
\hline & {$[0.001]$} & {$[0.282]$} & {$[1.000]$} & {$[0.084]$} & {$[1.000]$} & {$[1.000]$} \\
\hline \multirow[t]{3}{*}{ State election year } & $-0.039 * *$ & $0.058 * *$ & 0.008 & 0.056 & -0.022 & $0.071+$ \\
\hline & $(0.012)$ & $(0.014)$ & $(0.016)$ & $(0.026)$ & $(0.017)$ & $(0.028)$ \\
\hline & {$[0.005]$} & {$[0.000]$} & {$[1.000]$} & {$[0.198]$} & {$[1.000]$} & {$[0.066]$} \\
\hline \multirow[t]{3}{*}{ State pre-election year } & -0.012 & $0.062 * *$ & $0.037+$ & 0.015 & 0.015 & 0.017 \\
\hline & $(0.008)$ & $(0.013)$ & $(0.014)$ & $(0.022)$ & $(0.015)$ & $(0.029)$ \\
\hline & {$[0.834]$} & {$[0.000]$} & [0.053] & {$[1.000]$} & {$[1.000]$} & {$[1.000]$} \\
\hline MOV in state elections $\times$ & -0.070 & $0.225 *$ & 0.066 & 0.154 & 0.022 & 0.146 \\
\hline \multirow[t]{2}{*}{ local post-election year } & $(0.058)$ & $(0.077)$ & $(0.080)$ & $(0.139)$ & $(0.083)$ & $(0.177)$ \\
\hline & {$[1.000]$} & {$[0.021]$} & {$[1.000]$} & {$[1.000]$} & {$[1.000]$} & {$[1.000]$} \\
\hline \multirow{3}{*}{$\begin{array}{l}\text { MOV in state elections } \times \\
\text { local election year }\end{array}$} & 0.073 & $0.197 *$ & 0.166 & -0.053 & 0.079 & 0.267 \\
\hline & $(0.055)$ & $(0.072)$ & $(0.079)$ & $(0.139)$ & $(0.077)$ & $(0.181)$ \\
\hline & {$[1.000]$} & {$[0.039]$} & {$[0.224]$} & {$[1.000]$} & {$[1.000]$} & {$[0.844]$} \\
\hline \multirow{3}{*}{$\begin{array}{l}\text { MOV in state elections } \times \\
\text { local pre-election year }\end{array}$} & $0.141 *$ & 0.097 & 0.144 & -0.000 & 0.102 & 0.041 \\
\hline & $(0.050)$ & $(0.062)$ & $(0.070)$ & $(0.104)$ & $(0.071)$ & $(0.165)$ \\
\hline & {$[0.027]$} & {$[0.711]$} & {$[0.241]$} & {$[1.000]$} & {$[0.909]$} & {$[1.000]$} \\
\hline \multirow{3}{*}{$\begin{array}{l}\text { MOV in state elections } \times \\
\text { state post-election year }\end{array}$} & 0.098 & -0.071 & -0.029 & -0.080 & -0.142 & 0.188 \\
\hline & $(0.063)$ & $(0.064)$ & $(0.067)$ & $(0.110)$ & $(0.071)$ & $(0.119)$ \\
\hline & {$[0.740]$} & [1.000] & {$[1.000]$} & {$[1.000]$} & {$[0.265]$} & {$[0.696]$} \\
\hline \multirow{3}{*}{$\begin{array}{l}\text { MOV in state elections } \times \\
\text { state election year }\end{array}$} & $0.213 * *$ & -0.004 & -0.029 & 0.049 & 0.063 & 0.163 \\
\hline & $(0.067)$ & $(0.077)$ & $(0.076)$ & $(0.134)$ & $(0.088)$ & $(0.157)$ \\
\hline & {$[0.009]$} & {$[1.000]$} & {$[1.000]$} & {$[1.000]$} & {$[1.000]$} & {$[1.000]$} \\
\hline \multirow{3}{*}{$\begin{array}{l}\text { MOV in state elections } \times \\
\text { state pre-election year }\end{array}$} & 0.067 & $-0.169 *$ & 0.011 & 0.005 & 0.016 & -0.171 \\
\hline & $(0.041)$ & $(0.060)$ & $(0.069)$ & $(0.121)$ & $(0.072)$ & $(0.168)$ \\
\hline & {$[0.643]$} & {$[0.031]$} & {$[1.000]$} & {$[1.000]$} & {$[1.000]$} & {$[1.000]$} \\
\hline \multirow{3}{*}{$\begin{array}{l}\text { Margin of victory in past } \\
\text { state elections }\end{array}$} & -0.106 & 0.062 & 0.123 & 0.349 & 0.133 & $0.676 * *$ \\
\hline & $(0.109)$ & $(0.113)$ & $(0.113)$ & $(0.163)$ & $(0.132)$ & $(0.180)$ \\
\hline & {$[1.000]$} & {$[1.000]$} & {$[1.000]$} & {$[0.191]$} & {$[1.000]$} & {$[0.001]$} \\
\hline Lagged state unemployment & $0.249 * *$ & $0.079 * *$ & $0.037 * *$ & $-0.153 * *$ & -0.004 & $-0.099 * *$ \\
\hline & $(0.010)$ & $(0.011)$ & $(0.011)$ & $(0.015)$ & $(0.011)$ & $(0.017)$ \\
\hline & {$[0.000]$} & {$[0.000]$} & {$[0.008]$} & {$[0.000]$} & {$[1.000]$} & [0.000] \\
\hline Lagged state GDP pc. & $-0.050 * *$ & $-0.031 * *$ & 0.021 & $-0.055 * *$ & $0.039 * *$ & $-0.065 * *$ \\
\hline & $(0.010)$ & (0.009) & (0.009) & $(0.011)$ & $(0.009)$ & $(0.012)$ \\
\hline & {$[0.000]$} & [0.003] & {$[0.119]$} & {$[0.000]$} & {$[0.000]$} & {$[0.000]$} \\
\hline Lagged state GDP growth rate & $0.038 * *$ & 0.011 & $0.026 * *$ & $0.039 * *$ & 0.000 & $0.035 * *$ \\
\hline & $(0.004)$ & $(0.006)$ & $(0.007)$ & $(0.009)$ & $(0.005)$ & $(0.009)$ \\
\hline & {$[0.000]$} & {$[0.402]$} & {$[0.002]$} & {$[0.000]$} & {$[1.000]$} & {$[0.000]$} \\
\hline & 10 & 1 & 102 & 10 & 10100 & 13198 \\
\hline No. municipalities & 551 & 548 & 547 & 549 & 551 & 548 \\
\hline
\end{tabular}

Notes: The models rely on standardized dependent variables, originally measured in constant Euro per capita, except for the tax rate which is the standardized first principal component of three local tax multipliers. All models control for local population and an indicator for directly elected mayors. The six equations are jointly estimated in a seemingly unrelated regression (SUR) framework, controlling for municipality and year fixed effects. Standard errors clustered at the municipality level are presented in parentheses. Bonferroni-adjusted p-values (adjusted for multiple variable testing) are reported in square brackets. $+/^{*} / * *$ denote significance at the $10 / 5 / 1 \%$ level, adjusted for multiple variable testing. 
Table A7: Robustness: Partisanship alignment and cycles with state controls (GMM w. year FE)

\begin{tabular}{|c|c|c|c|c|c|c|}
\hline \multirow{3}{*}{ Dependent variable } & \multirow{3}{*}{$\begin{array}{c}(1) \\
\text { Local } \\
\text { tax rates }\end{array}$} & $(2)$ & $(3)$ & \multirow{3}{*}{$\begin{array}{c}(4) \\
\text { Building } \\
\text { investment }\end{array}$} & \multirow{3}{*}{$\begin{array}{c}\text { (5) } \\
\text { Admin. } \\
\text { grants }\end{array}$} & \multirow{3}{*}{$\begin{array}{c}\text { (6) } \\
\text { Invest. } \\
\text { grants }\end{array}$} \\
\hline & & \multicolumn{2}{|c|}{ Current account } & & & \\
\hline & & Expend. & Revenues & & & \\
\hline Local post-election year & $\begin{array}{r}-0.015 \\
(0.013)\end{array}$ & $\begin{array}{c}0.031 \\
(0.030)\end{array}$ & $\begin{array}{c}0.019 \\
(0.033)\end{array}$ & $\begin{array}{c}-0.021 \\
(0.022)\end{array}$ & $\begin{array}{c}-0.070 * * \\
(0.027)\end{array}$ & $\begin{array}{l}0.187 * * \\
(0.044)\end{array}$ \\
\hline Local election year & $\begin{array}{c}-0.064 * * \\
(0.014)\end{array}$ & $\begin{array}{c}-0.015 \\
(0.028)\end{array}$ & $\begin{array}{c}-0.079 * \\
(0.033)\end{array}$ & $\begin{array}{c}0.042+ \\
(0.025)\end{array}$ & $\begin{array}{c}-0.108 * * \\
(0.029)\end{array}$ & $\begin{array}{l}0.283 * * \\
(0.049)\end{array}$ \\
\hline Local pre-election year & $\begin{array}{c}0.024+ \\
(0.013)\end{array}$ & $\begin{array}{c}-0.003 \\
(0.023)\end{array}$ & $\begin{array}{c}-0.111 * * \\
(0.026)\end{array}$ & $\begin{array}{c}0.014 \\
(0.021)\end{array}$ & $\begin{array}{c}-0.150 * * \\
(0.025)\end{array}$ & $\begin{array}{l}0.110 * * \\
(0.040)\end{array}$ \\
\hline State post-election year & $\begin{array}{c}-0.069 * * \\
(0.012)\end{array}$ & $\begin{array}{c}-0.005 \\
(0.022)\end{array}$ & $\begin{array}{c}-0.042 \\
(0.029)\end{array}$ & $\begin{array}{c}0.031 \\
(0.024)\end{array}$ & $\begin{array}{c}-0.095 * * \\
(0.026)\end{array}$ & $\begin{array}{c}0.017 \\
(0.044)\end{array}$ \\
\hline State election year & $\begin{array}{c}-0.051 * * \\
(0.014)\end{array}$ & $\begin{array}{r}-0.033 \\
(0.030)\end{array}$ & $\begin{array}{r}-0.058 \\
(0.036)\end{array}$ & $\begin{array}{c}0.045+ \\
(0.024)\end{array}$ & $\begin{array}{c}-0.131 * * \\
(0.026)\end{array}$ & $\begin{array}{c}0.114 * \\
(0.048)\end{array}$ \\
\hline State pre-election year & $\begin{array}{r}-0.029 * \\
(0.014)\end{array}$ & $\begin{array}{c}0.036 \\
(0.031)\end{array}$ & $\begin{array}{r}-0.019 \\
(0.032)\end{array}$ & $\begin{array}{c}0.014 \\
(0.022)\end{array}$ & $\begin{array}{c}-0.048+ \\
(0.027)\end{array}$ & $\begin{array}{r}-0.041 \\
(0.049)\end{array}$ \\
\hline $\begin{array}{l}\text { Partisan alignment } \times \\
\text { local post-election year }\end{array}$ & $\begin{array}{c}0.044 * \\
(0.018)\end{array}$ & $\begin{array}{r}-0.099 * \\
(0.047)\end{array}$ & $\begin{array}{r}-0.051 \\
(0.049)\end{array}$ & $\begin{array}{r}-0.038 \\
(0.030)\end{array}$ & $\begin{array}{l}0.118 * * \\
(0.043)\end{array}$ & $\begin{array}{c}-0.251 * * \\
(0.071)\end{array}$ \\
\hline $\begin{array}{l}\text { Partisan alignment } \times \\
\text { local election year }\end{array}$ & $\begin{array}{c}0.019 \\
(0.020)\end{array}$ & $\begin{array}{r}-0.019 \\
(0.042)\end{array}$ & $\begin{array}{c}0.081 \\
(0.052)\end{array}$ & $\begin{array}{r}-0.029 \\
(0.031)\end{array}$ & $\begin{array}{l}0.140 * * \\
(0.044)\end{array}$ & $\begin{array}{c}-0.321 * * \\
(0.078)\end{array}$ \\
\hline $\begin{array}{l}\text { Partisan alignment } \times \\
\text { local pre-election year }\end{array}$ & $\begin{array}{c}-0.050 * * \\
(0.018)\end{array}$ & $\begin{array}{r}-0.012 \\
(0.032)\end{array}$ & $\begin{array}{c}0.093 * \\
(0.040)\end{array}$ & $\begin{array}{c}0.027 \\
(0.027)\end{array}$ & $\begin{array}{l}0.175 * * \\
(0.037)\end{array}$ & $\begin{array}{r}-0.068 \\
(0.061)\end{array}$ \\
\hline $\begin{array}{l}\text { Partisan alignment } \times \\
\text { state post-election year }\end{array}$ & $\begin{array}{l}0.078 * * \\
(0.018)\end{array}$ & $\begin{array}{r}-0.020 \\
(0.035)\end{array}$ & $\begin{array}{c}0.031 \\
(0.044)\end{array}$ & $\begin{array}{r}-0.006 \\
(0.030)\end{array}$ & $\begin{array}{l}0.125 * * \\
(0.039)\end{array}$ & $\begin{array}{r}-0.045 \\
(0.066)\end{array}$ \\
\hline $\begin{array}{l}\text { Partisan alignment } \times \\
\text { state election year }\end{array}$ & $\begin{array}{c}0.021 \\
(0.021)\end{array}$ & $\begin{array}{c}0.087 * \\
(0.044)\end{array}$ & $\begin{array}{c}0.028 \\
(0.054)\end{array}$ & $\begin{array}{c}0.029 \\
(0.031)\end{array}$ & $\begin{array}{l}0.174 * * \\
(0.040)\end{array}$ & $\begin{array}{r}-0.090 \\
(0.074)\end{array}$ \\
\hline $\begin{array}{l}\text { Partisan alignment } \times \\
\text { state pre-election year }\end{array}$ & $\begin{array}{c}0.018 \\
(0.021)\end{array}$ & $\begin{array}{r}-0.017 \\
(0.046)\end{array}$ & $\begin{array}{c}0.082 \\
(0.050)\end{array}$ & $\begin{array}{c}0.036 \\
(0.028)\end{array}$ & $\begin{array}{c}0.102 * \\
(0.043)\end{array}$ & $\begin{array}{c}0.053 \\
(0.078)\end{array}$ \\
\hline $\begin{array}{l}\text { Partisan alignment } \\
\text { state-local gov. }\end{array}$ & $\begin{array}{c}-0.077 * * \\
(0.019)\end{array}$ & $\begin{array}{c}0.029 \\
(0.038)\end{array}$ & $\begin{array}{r}-0.092 * \\
(0.041)\end{array}$ & $\begin{array}{c}0.038 \\
(0.030)\end{array}$ & $\begin{array}{c}-0.235 * * \\
(0.041)\end{array}$ & $\begin{array}{l}0.307 * * \\
(0.066)\end{array}$ \\
\hline Lagged dependent (t-1) & $\begin{array}{l}0.859 * * \\
(0.011)\end{array}$ & $\begin{array}{l}0.595 * * \\
(0.037)\end{array}$ & $\begin{array}{l}0.542 * * \\
(0.034)\end{array}$ & $\begin{array}{l}0.409 * * \\
(0.037)\end{array}$ & $\begin{array}{l}0.402 * * \\
(0.026)\end{array}$ & $\begin{array}{l}0.257 * * \\
(0.035)\end{array}$ \\
\hline Lagged dependent (t-2) & & $\begin{array}{l}0.136 * * \\
(0.036)\end{array}$ & $\begin{array}{l}0.149 * * \\
(0.036)\end{array}$ & $\begin{array}{c}-0.067+ \\
(0.038)\end{array}$ & $\begin{array}{l}0.195 * * \\
(0.028)\end{array}$ & $\begin{array}{c}0.086 * \\
(0.035)\end{array}$ \\
\hline Lagged dependent (t-3) & & & $\begin{array}{c}0.017 \\
(0.029)\end{array}$ & $\begin{array}{c}0.056 * \\
(0.027)\end{array}$ & $\begin{array}{l}0.069 * * \\
(0.025)\end{array}$ & $\begin{array}{c}0.006 \\
(0.026)\end{array}$ \\
\hline $\begin{array}{l}\text { Lagged state unemployment } \\
\text { rate }\end{array}$ & $\begin{array}{c}0.006 * \\
(0.003)\end{array}$ & $\begin{array}{c}0.001 \\
(0.007)\end{array}$ & $\begin{array}{r}-0.008 \\
(0.008)\end{array}$ & $\begin{array}{c}-0.044 * * \\
(0.014)\end{array}$ & $\begin{array}{c}0.005 \\
(0.007)\end{array}$ & $\begin{array}{c}-0.066 * * \\
(0.017)\end{array}$ \\
\hline Lagged state GDP pc. & $\begin{array}{c}-0.019 * * \\
(0.005)\end{array}$ & $\begin{array}{r}-0.019 * \\
(0.009)\end{array}$ & $\begin{array}{c}0.006 \\
(0.012)\end{array}$ & $\begin{array}{c}0.016 \\
(0.016)\end{array}$ & $\begin{array}{l}0.038 * * \\
(0.009)\end{array}$ & $\begin{array}{r}-0.041 * \\
(0.019)\end{array}$ \\
\hline $\begin{array}{l}\text { Lagged state GDP } \\
\text { growth rate }\end{array}$ & $\begin{array}{c}0.003 \\
(0.002)\end{array}$ & $\begin{array}{c}-0.001 \\
(0.005)\end{array}$ & $\begin{array}{c}0.009+ \\
(0.005)\end{array}$ & $\begin{array}{l}0.030 * * \\
(0.007)\end{array}$ & $\begin{array}{c}-0.009+ \\
(0.005)\end{array}$ & $\begin{array}{l}0.027 * * \\
(0.008)\end{array}$ \\
\hline No. observations & 14445 & 13669 & 13269 & 13112 & 12942 & 12891 \\
\hline $\mathrm{AR}(1) \mathrm{p}$-value & 0.000 & 0.000 & 0.000 & 0.000 & 0.000 & 0.000 \\
\hline $\mathrm{AR}(2) \mathrm{p}$-value & 0.159 & 0.249 & 0.412 & 0.517 & 0.460 & 0.388 \\
\hline Hansen Test p-value & 0.681 & 0.247 & 0.364 & 0.999 & 0.992 & 0.992 \\
\hline
\end{tabular}

Notes: The models rely on standardized dependent variables, originally measured in constant Euro per capita, except for the tax rate which is the standardized first principal component of three local tax multipliers. The six equations are estimated by the General Method of Moments, controlling for year fixed effects. The applied difference GMM estimation procedure relies on two-step estimation without fitting a constant. The variables population, directly elected mayor, lagged state unemployment rate, lagged state GDP and lagged state GDP growth rate are considered as predetermined. All models use lags 4-7 of the dependent variable as instruments (the equation on current expenditures uses lags 4-6). Standard errors clustered at the municipality level are presented in parentheses. $+,{ }^{*}, * *$ denote significance at the $10 / 5 / 1 \%$. 
Table A8: Robustness: Electoral competition and cycles with state controls (GMM w. year FE)

\begin{tabular}{|c|c|c|c|c|c|c|}
\hline \multirow{3}{*}{ Dependent variable } & \multirow{3}{*}{$\begin{array}{c}(1) \\
\text { Local } \\
\text { tax rates }\end{array}$} & $(2)$ & (3) & \multirow{3}{*}{$\begin{array}{c}(4) \\
\text { Building } \\
\text { investment }\end{array}$} & \multirow{3}{*}{$\begin{array}{c}\text { (5) } \\
\text { Admin. } \\
\text { grants }\end{array}$} & \multirow{3}{*}{$\begin{array}{c}\quad(6) \\
\text { Invest. } \\
\text { grants }\end{array}$} \\
\hline & & \multicolumn{2}{|c|}{ Current account } & & & \\
\hline & & Expend. & Revenues & & & \\
\hline Local post-election year & $\begin{array}{l}0.055 * * \\
(0.018)\end{array}$ & $\begin{array}{r}-0.086 * \\
(0.035)\end{array}$ & $\begin{array}{c}0.013 \\
(0.043)\end{array}$ & $\begin{array}{l}0.009 \\
(0.027)\end{array}$ & $\begin{array}{c}-0.024 \\
(0.038)\end{array}$ & $\begin{array}{c}0.030 \\
(0.061)\end{array}$ \\
\hline Local election year & $\begin{array}{r}-0.037 * \\
(0.018)\end{array}$ & $\begin{array}{c}-0.109 * * \\
(0.038)\end{array}$ & $\begin{array}{r}-0.111 * \\
(0.045)\end{array}$ & $\begin{array}{l}0.096 * * \\
(0.028)\end{array}$ & $\begin{array}{c}-0.065+ \\
(0.035)\end{array}$ & $\begin{array}{c}0.156 * \\
(0.070)\end{array}$ \\
\hline Local pre-election year & $\begin{array}{c}0.025 \\
(0.016)\end{array}$ & $\begin{array}{r}-0.070 * \\
(0.029)\end{array}$ & $\begin{array}{c}-0.132 * * \\
(0.038)\end{array}$ & $\begin{array}{l}0.063 * * \\
(0.024)\end{array}$ & $\begin{array}{c}0.013 \\
(0.031)\end{array}$ & $\begin{array}{c}0.100+ \\
(0.056)\end{array}$ \\
\hline State post-election year & $\begin{array}{c}-0.059 * * \\
(0.016)\end{array}$ & $\begin{array}{c}0.033 \\
(0.029)\end{array}$ & $\begin{array}{c}-0.037 \\
(0.036)\end{array}$ & $\begin{array}{c}0.056 * \\
(0.026)\end{array}$ & $\begin{array}{c}0.037 \\
(0.031)\end{array}$ & $\begin{array}{c}-0.066 \\
(0.052)\end{array}$ \\
\hline State election year & $\begin{array}{c}-0.047 * * \\
(0.016)\end{array}$ & $\begin{array}{r}-0.028 \\
(0.036)\end{array}$ & $\begin{array}{r}-0.078 * \\
(0.040)\end{array}$ & $\begin{array}{c}0.054 * \\
(0.024)\end{array}$ & $\begin{array}{c}-0.056 \\
(0.036)\end{array}$ & $\begin{array}{c}0.113+ \\
(0.062)\end{array}$ \\
\hline State pre-election year & $\begin{array}{c}-0.060 * * \\
(0.017)\end{array}$ & $\begin{array}{l}0.089 * * \\
(0.032)\end{array}$ & $\begin{array}{c}-0.037 \\
(0.034)\end{array}$ & $\begin{array}{c}0.024 \\
(0.023)\end{array}$ & $\begin{array}{c}0.032 \\
(0.032)\end{array}$ & $\begin{array}{c}0.063 \\
(0.054)\end{array}$ \\
\hline $\begin{array}{l}\text { MOV in state elections } \times \\
\text { local post-election year }\end{array}$ & $\begin{array}{c}-0.340 * * \\
(0.106)\end{array}$ & $\begin{array}{c}0.242 \\
(0.221)\end{array}$ & $\begin{array}{c}-0.134 \\
(0.262)\end{array}$ & $\begin{array}{c}-0.293+ \\
(0.152)\end{array}$ & $\begin{array}{l}0.178 \\
(0.240)\end{array}$ & $\begin{array}{c}0.058 \\
(0.398)\end{array}$ \\
\hline $\begin{array}{l}\text { MOV in state elections } \times \\
\text { local election year }\end{array}$ & $\begin{array}{c}0.018 \\
(0.114)\end{array}$ & $\begin{array}{l}0.628 * * \\
(0.240)\end{array}$ & $\begin{array}{c}0.493+ \\
(0.292)\end{array}$ & $\begin{array}{r}-0.373 * \\
(0.147)\end{array}$ & $\begin{array}{c}0.282 \\
(0.218)\end{array}$ & $\begin{array}{c}-0.394 \\
(0.460)\end{array}$ \\
\hline $\begin{array}{l}\text { MOV in state elections } \times \\
\text { local pre-election year }\end{array}$ & $\begin{array}{r}-0.206 * \\
(0.093)\end{array}$ & $\begin{array}{l}0.456 * * \\
(0.164)\end{array}$ & $\begin{array}{c}0.398+ \\
(0.230)\end{array}$ & $\begin{array}{c}-0.158 \\
(0.124)\end{array}$ & $\begin{array}{c}-0.336+ \\
(0.181)\end{array}$ & $\begin{array}{c}0.001 \\
(0.346)\end{array}$ \\
\hline $\begin{array}{l}\text { MOV in state elections } \times \\
\text { state post-election year }\end{array}$ & $\begin{array}{l}0.266 * * \\
(0.097)\end{array}$ & $\begin{array}{r}-0.262 \\
(0.169)\end{array}$ & $\begin{array}{c}-0.010 \\
(0.214)\end{array}$ & $\begin{array}{r}-0.137 \\
(0.135)\end{array}$ & $\begin{array}{r}-0.364 * \\
(0.181)\end{array}$ & $\begin{array}{c}0.366 \\
(0.308)\end{array}$ \\
\hline $\begin{array}{l}\text { MOV in state elections } \times \\
\text { state election year }\end{array}$ & $\begin{array}{c}0.038 \\
(0.099)\end{array}$ & $\begin{array}{c}0.434+ \\
(0.224)\end{array}$ & $\begin{array}{c}0.233 \\
(0.246)\end{array}$ & $\begin{array}{l}0.136 \\
(0.140)\end{array}$ & $\begin{array}{c}0.162 \\
(0.206)\end{array}$ & $\begin{array}{c}-0.033 \\
(0.398)\end{array}$ \\
\hline $\begin{array}{l}\text { MOV in state elections } \times \\
\text { state pre-election year }\end{array}$ & $\begin{array}{l}0.282 * * \\
(0.105)\end{array}$ & $\begin{array}{c}-0.342+ \\
(0.195)\end{array}$ & $\begin{array}{c}0.324 \\
(0.206)\end{array}$ & $\begin{array}{c}0.156 \\
(0.130)\end{array}$ & $\begin{array}{c}-0.211 \\
(0.189)\end{array}$ & $\begin{array}{c}-0.392 \\
(0.331)\end{array}$ \\
\hline $\begin{array}{l}\text { Margin of victory in } \\
\text { state elections }\end{array}$ & $\begin{array}{c}-0.298 * * \\
(0.106)\end{array}$ & $\begin{array}{r}-0.431 * \\
(0.173)\end{array}$ & $\begin{array}{c}-0.052 \\
(0.233)\end{array}$ & $\begin{array}{l}0.708 * * \\
(0.218)\end{array}$ & $\begin{array}{r}-0.468 * \\
(0.203)\end{array}$ & $\begin{array}{l}1.037 * * \\
(0.372)\end{array}$ \\
\hline Lagged dependent (t-1) & $\begin{array}{l}0.881 * * \\
(0.010)\end{array}$ & $\begin{array}{l}0.577 * * \\
(0.040)\end{array}$ & $\begin{array}{l}0.524 * * \\
(0.040)\end{array}$ & $\begin{array}{l}0.394 * * \\
(0.037)\end{array}$ & $\begin{array}{l}0.399 * * \\
(0.030)\end{array}$ & $\begin{array}{l}0.282 * * \\
(0.035)\end{array}$ \\
\hline Lagged dependent (t-2) & & $\begin{array}{l}0.187 * * \\
(0.038)\end{array}$ & $\begin{array}{l}0.188 * * \\
(0.040)\end{array}$ & $\begin{array}{r}-0.071 * \\
(0.033)\end{array}$ & $\begin{array}{l}0.198 * * \\
(0.029)\end{array}$ & $\begin{array}{c}0.058 \\
(0.036)\end{array}$ \\
\hline Lagged dependent (t-3) & & & $\begin{array}{c}0.005 \\
(0.030)\end{array}$ & $\begin{array}{c}0.050 * \\
(0.024)\end{array}$ & $\begin{array}{r}0.065 * \\
(0.026)\end{array}$ & $\begin{array}{c}0.012 \\
(0.025)\end{array}$ \\
\hline $\begin{array}{l}\text { Lagged state unemployment } \\
\text { rate }\end{array}$ & $\begin{array}{l}0.008 * * \\
(0.003)\end{array}$ & $\begin{array}{c}0.002 \\
(0.007)\end{array}$ & $\begin{array}{l}-0.026 * * \\
(0.009)\end{array}$ & $\begin{array}{c}-0.059 * * \\
(0.016)\end{array}$ & $\begin{array}{c}0.011 \\
(0.008)\end{array}$ & $\begin{array}{c}-0.067 * * \\
(0.017)\end{array}$ \\
\hline Lagged state GDP pc. & $\begin{array}{c}-0.015 * * \\
(0.004)\end{array}$ & $\begin{array}{r}-0.015 \\
(0.009)\end{array}$ & $\begin{array}{c}0.007 \\
(0.012)\end{array}$ & $\begin{array}{c}0.012 \\
(0.017)\end{array}$ & $\begin{array}{l}0.058 * * \\
(0.010)\end{array}$ & $\begin{array}{c}-0.068 * * \\
(0.021)\end{array}$ \\
\hline $\begin{array}{l}\text { Lagged state GDP } \\
\text { growth rate }\end{array}$ & $\begin{array}{c}0.002 \\
(0.003)\end{array}$ & $\begin{array}{c}-0.004 \\
(0.005)\end{array}$ & $\begin{array}{r}0.014 * \\
(0.006)\end{array}$ & $\begin{array}{l}0.033 * * \\
(0.008)\end{array}$ & $\begin{array}{c}-0.010+ \\
(0.005)\end{array}$ & $\begin{array}{l}0.031 * * \\
(0.008)\end{array}$ \\
\hline No. observations & 12641 & 11931 & 11541 & 11419 & 11357 & 11223 \\
\hline $\mathrm{AR}(1) \mathrm{p}$-value & 0.000 & 0.000 & 0.000 & 0.000 & 0.000 & 0.000 \\
\hline $\mathrm{AR}(2) \mathrm{p}$-value & 0.739 & 0.873 & 0.107 & 0.569 & 0.528 & 0.838 \\
\hline Hansen Test p-value & 0.928 & 0.998 & 0.655 & 1.000 & 0.999 & 0.998 \\
\hline
\end{tabular}

Notes: The models rely on standardized dependent variables, originally measured in constant Euro per capita, except for the tax rate which is the standardized first principal component of three local tax multipliers. The six equations are estimated by the General Method of Moments, controlling for year fixed effects. The applied difference GMM estimation procedure relies on two-step estimation without fitting a constant. The variables population, directly elected mayor, lagged state unemployment rate, lagged state GDP and lagged state GDP growth rate are considered as predetermined. All models use lags 4-7 of the dependent variable as instruments (the equation on current expenditures uses lags 4-6). Standard errors clustered at the municipality level are presented in parentheses. $+,{ }^{*},{ }^{* *}$ denote significance at the $10 / 5 / 1 \%$. 